\author{
UNIVERSIDADE DE SÃO PAULO \\ FACULDADE DE CIÊNCIAS FARMACÊUTICAS \\ Programa de Pós-Graduação em Fármaco e Medicamentos \\ Área de Produção e Controle Farmacêuticos
}

\title{
ESTUDO COMPARATIVO "in vitro" ENTRE PREPARAÇÕES DE IMUNOGLOBULINA G, PARA USO INTRAVENOSO, OBTIDAS DE PLASMA HUMANO DE VARIADAS PROCEDÊNCIAS E PROCESSADAS POR DIFERENTES TÉCNICAS DE SEPARAÇÃO
}

\section{GENY APARECIDA DE OLIVEIRA BARNA}

Tese apresentada para obtenção do grau de DOUTOR

Orientador:

Prof. Titular DALTON A. F. CHAMONE

São Paulo

2001 


\section{UNIVERSIDADE DE SÃO PAULO \\ FACULDADE DE CIÊNCIAS FARMACÊUTICAS}

Programa de Pós-Graduação em Fármaco e Medicamentos

Área de Produção e Controle Farmacêuticos

ESTUDO COMPARATIVO "in vitro" ENTRE PREPARAÇÕES

DE IMUNOGLOBULINA G, PARA USO INTRAVENOSO, OBTIDAS DE PLASMA HUMANO DE VARIADAS

PROCEDÊNCIAS E PROCESSADAS POR DIFERENTES

TÉCNICAS DE SEPARAÇÃO

\section{GENY APARECIDA DE OLIVEIRA BARNA}

Tese apresentada para obtenção do grau

de DOUTOR

Orientador:

Prof. Titular DALTON A. F. CHAMONE

São Paulo

2001 


\title{
GENY APARECIDA DE OLIVEIRA BARNA
}

\author{
ESTUDO COMPARATIVO "in vitro" ENTRE PREPARAÇÕES DE \\ IMUNOGLOBULINA G, PARA USO INTRAVENOSO, OBTIDAS DE \\ PLASMA HUMANO DE VARIADAS PROCEDÊNCIAS E PROCESSADAS \\ POR DIFERENTES TÉCNICAS DE SEPARAÇÃO
}

COMISSÃO JULGADORA

TESE PARA OBTENÇÃO DO GRAU DE DOUTOR

Orientador/Presidente

Examinador(a)

Examinador(a)

Examinador(a)

Examinador(a)

São Paulo, 21 de junho de 2001 
A Deus, pelo dom da vida, da saúde e da inteligência Deus, dai-me forças de ajudar o progresso a fim de subir até Vós Dai-me sempre a fé e a razão 
À minha mãe Joanna,

por quem valeu a pena realizar

essa Tese, pelo eterno apoio,

incentivo, dedicação e amor.

Ao meu filho Guilherme Augusto, minha inesgotável fonte de coragem e inspiração para lutar pelas coisas nas quais acredito.

Ao meu marido Carlos, pela compreensão e paciência. 
Ao Prof. Dalton Chamone, pela orientação segura, pelo apoio incondicional, pelos exemplos de determinação, competência e seriedade. 
A todos os meus familiares, especialmente à minha irmã

Neide, e amigos que me apoiaram e incentivaram. 


\section{AGRADECI MENTOS ESPECI AIS}

- À Coordenadora do Programa de Pós-Graduação em Fármaco e Medicamentos, Profa. Dra. Maria Amélia Barata da Silveira, pela compreensão, grande apoio e sugestões.

- À Profa. Dra Celidéia A. C. Vaz, pela providencial orientação e pelas lições de vida.

- Ao Prof. Dr. Raul Maranhão, minha imensa e eterna gratidão, estima e admiração.

- À Profa. Dra. Bernadette D. G. de Melo Franco, Presidente da CPG/FCF/USP, pela compreensão e apoio.

- À Profa. Dra. Silvia R. C. J. Santos, pela oportunidade e iniciação.

- Aos Docentes da Faculdade de Ciências Farmacêuticas da Universidade de São Paulo, pela preciosa formação acadêmica e científica.

- À Secretária do Departamento de Fármaco e Medicamentos, Elizabete C. de Souza Paiva, pelo apoio, amizade e consideração.

- Aos funcionários da Secretaria de Pós-Graduação da Faculdade de Ciências Farmacêuticas - USP - Benedita, Elaine e Jorge pela eficiência.

- À Adriana de Almeida Barreiros, pela inestimável colaboração e amizade.

- À amiga Tânia Rúbia Flores da Rocha, pelas valiosas sugestões e pela demonstração de amizade.

- Ao amigo Dr. Élbio D'Amico, pelas importantes sugestões científicas.

- Ao Dr. Kimiyuki Tanaka, Eiko Sawatani, Emília Megumi Shigueco, Telma Cristina X.B. de Campos, Fernando Arashiro, Clóvis Fugita, Roseli S. Di Domenico e a todos os colegas da Divisão de Produção e Desenvolvimento Industrial da Fundação Pró-Sangue H/SP, pela irrestrita colaboração e apoio.

- À Nanci A. Salles, Chefe da Divisão de Sorologia da Fundação PróSangue H/SP, à Dra. Leda Bassit, à Dra. Claúdia Barreto, pela 
supervisão técnica laboratorial e a todos os funcionários e colegas, pela valiosa colaboração nas análises laboratoriais.

- A todos os colegas do Departamento de Imunologia do Laboratório Central, especialmente à Cristina e à Lúcia, pelo valioso auxílio nas análises.

- Ao Prof. Dr. João F. Magalhães, pelo infindável incentivo, orientações e sugestões.

- À Dra Ester Sabino, Dra Clarisse Martins Machado, Profa. Dra Edna Strauss pelas enriquecedoras análises e correções dos textos.

- Ao Prof. Dr. Sérgio Bydlowski, pela vital colaboração e apoio.

- Ao Dr. Mário Ivo, pelo irrestrito apoio.

- Aos amigos Magnanelli, Nair, Rosângela, Prof. Dr. Augusto, Madalena, Dra. Estela, Adriana e Alzira, pela estima e colaboração.

- Às minhas amigas Valéria, Adriana Issy, Maria das Dores, Célia, Silvana Matana, pela infinita torcida e apoio.

- Aos fabricantes dos Estados Unidos, da África do Sul e Índia que, muito gentilmente, doaram ao nosso estudo as preparações 2, 7 e 8, respectivamente.

- Aos colegas Marcelo Nunes, Márcio Wander do Carmo e André Sartori pelo suporte técnico em informática.

- Aos funcionários do Serviço de Reprodução Gráfica (FPS/HSP), pela inestimável colaboração.

- A todas as pessoas que, direta ou indiretamente, foram de vital importância para a realização do presente trabalho. 


\section{SUMÁRIO}

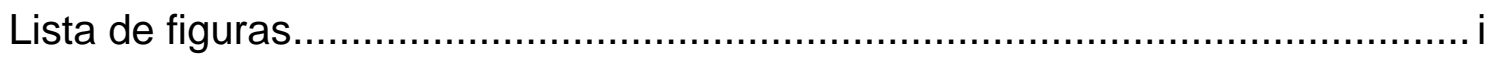

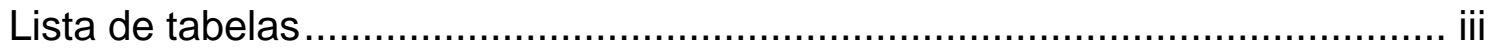

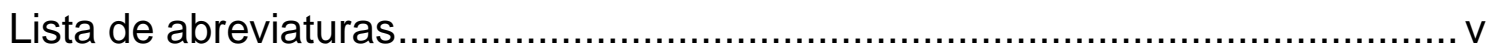

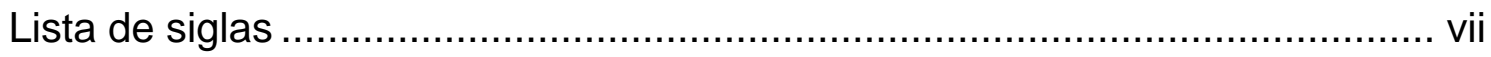

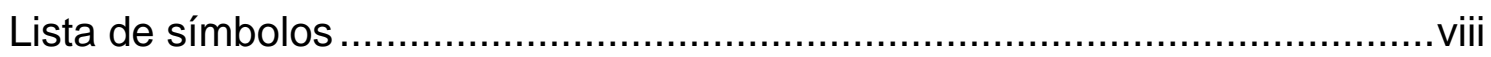

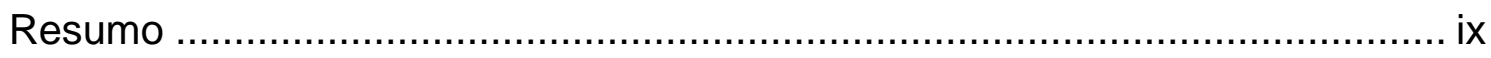

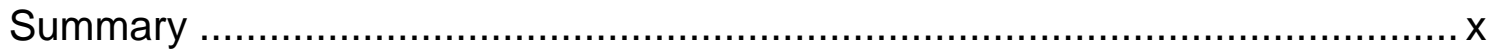

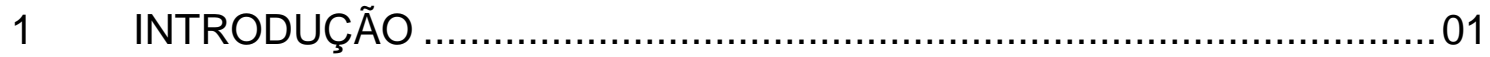

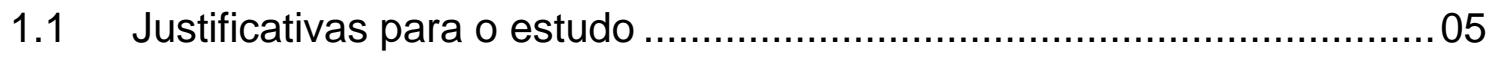

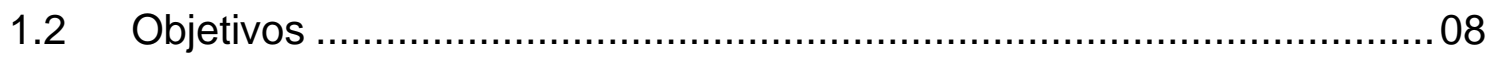

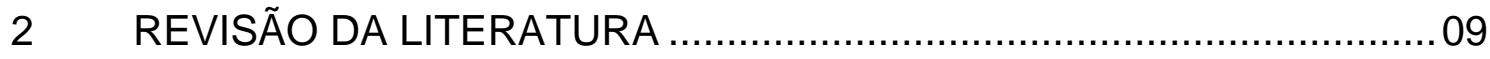

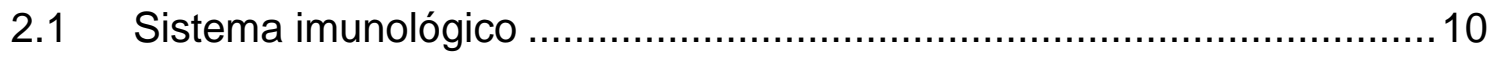

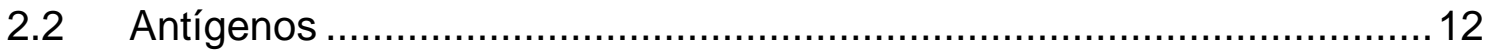

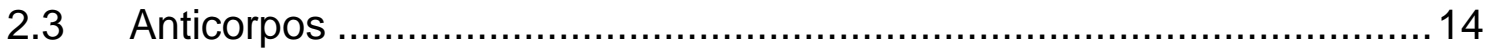

2.3.1 Estrutura básica molecular dos anticorpos...................................... 15

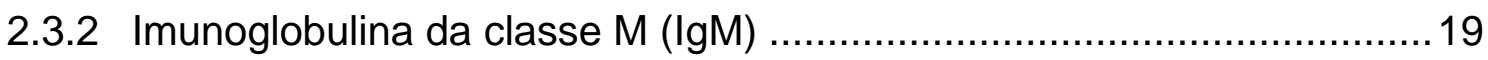

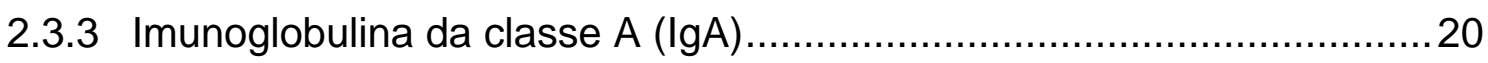

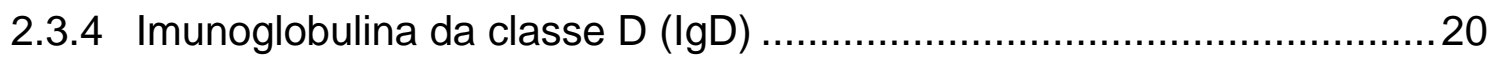

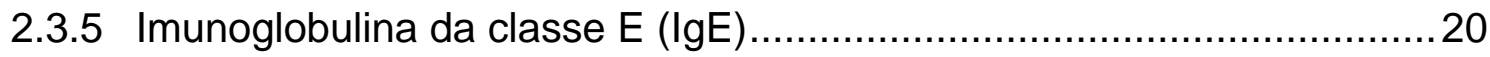

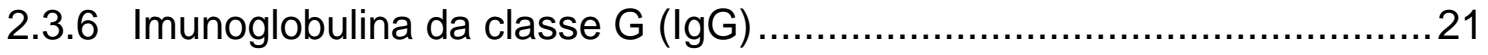

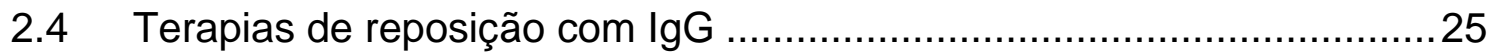

2.5 Tecnologias para obtenção e controle de qualidade de preparações

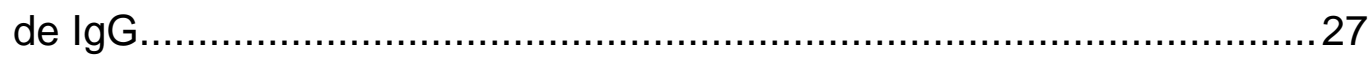

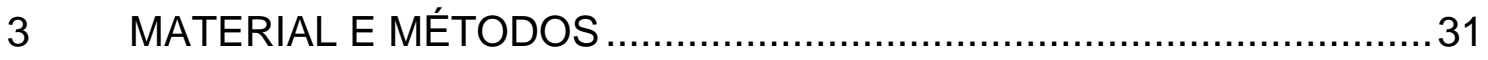

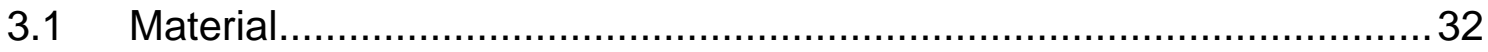

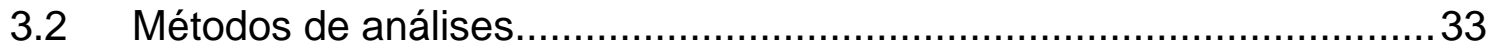

3.2.1 Determinação das subclasses IgG1, lgG2, IgG3 e IgG4 …................33

3.2.2 Testes laboratoriais de sorologia e biologia molecular...........................34 
3.2.2.1 Leucemia/linfoma de linfócitos $T$ do adulto e a paraparesia

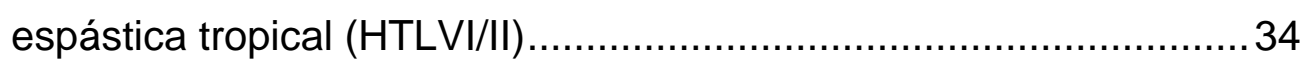

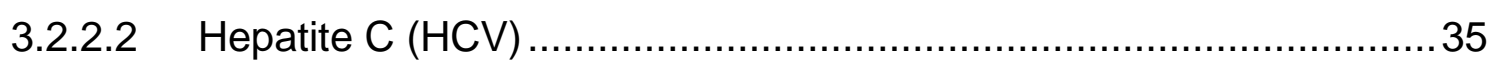

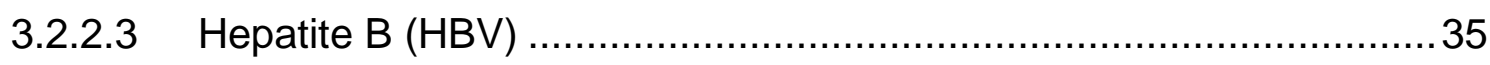

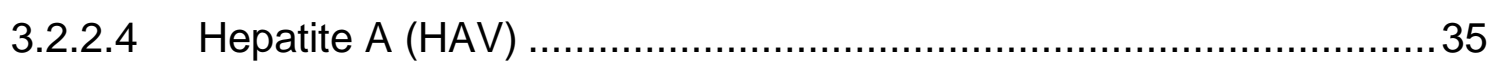

3.2.2.5 Síndrome da imunodeficiência adquirida (AIDS) (HIV 1/2) ..............35

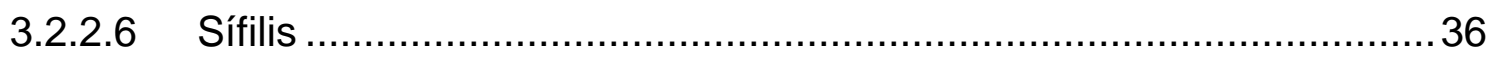

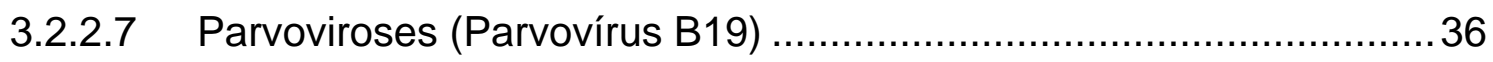

3.2.3 Testes de atividade para anticorpos específicos..................................... 37

3.2.3.1 Anticorpos anti-estreptolisina O (ASLO) ........................................ 37

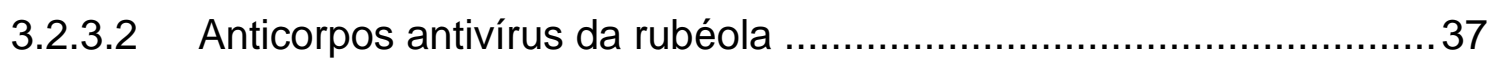

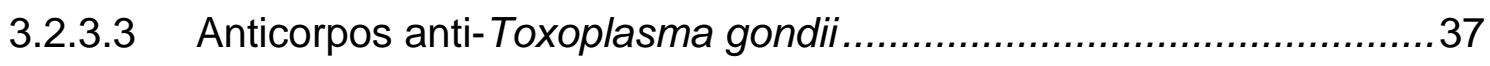

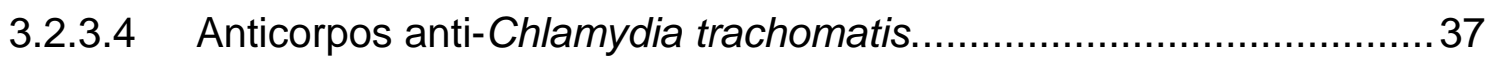

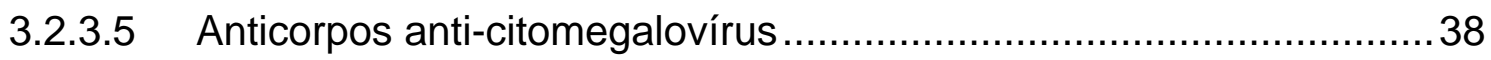

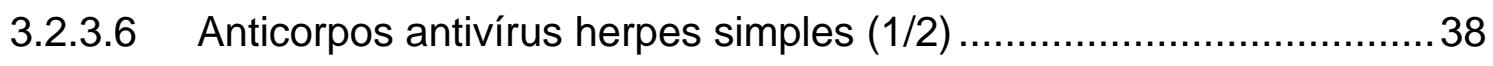

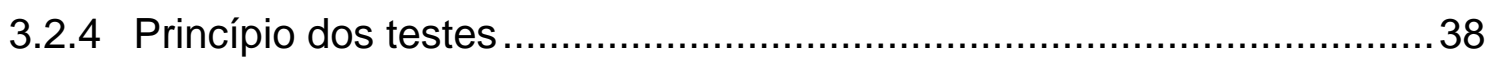

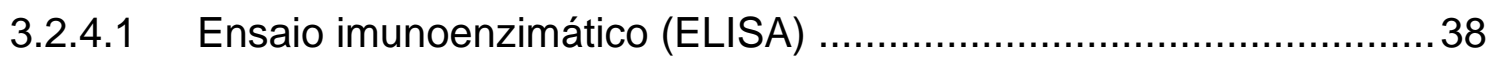

3.2.4.2 Técnica de biologia molecular (PCR) ......................................... 40

3.2.4.3 Imunofluorescência Indireta (IFI) ............................................. 42

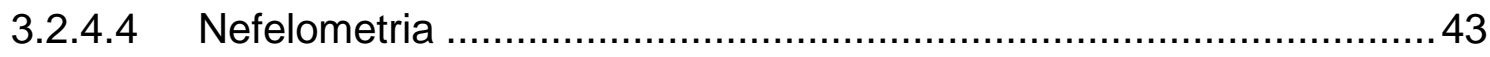

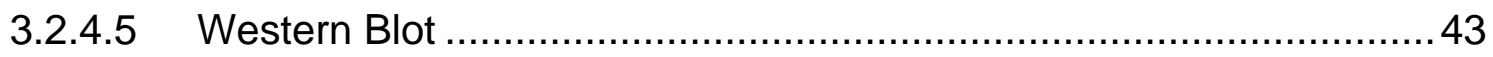

3.2.4.6 Teste de aglutinação de cristais de colesterol ................................ 45

3.2.5 Procedimentos industriais de separação e purificação de $\lg G$ obtida de plasma humano por cromatografia em coluna realizados na Fundação Pró-Sangue Hemocentro de São Paulo ................................ 45

3.2.5.1 Tratamento da matéria-prima ..................................................... 46

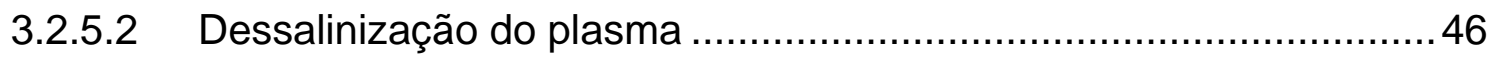

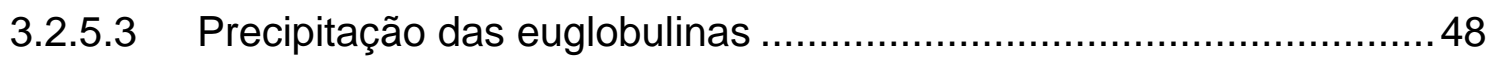

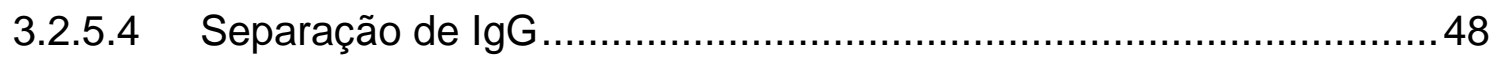

3.2.5.5 Procedimentos de inativação viral e purificação final da IgG ............ 49

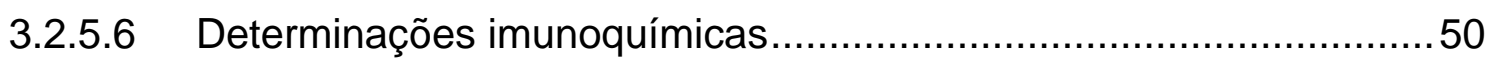

3.2.5.7 Determinação das proteínas totais ................................................ 50 


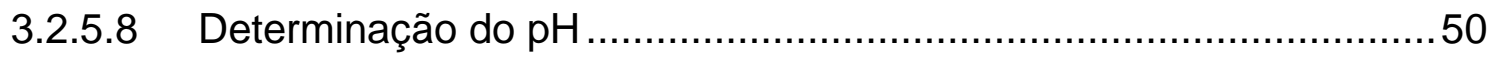

3.2.5.9 Determinação das hemaglutininas...................................... 51

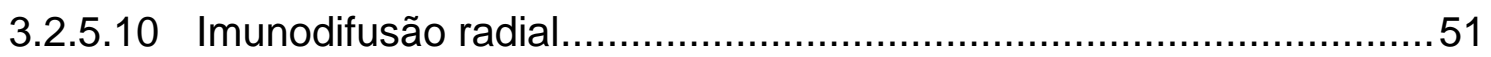

3.2.5.11 Determinação da atividade anticomplementar .............................51

3.2.5.12 Determinação do ativador da pré-cralicreína ................................51

3.2.5.13 Testes sorológicos ............................................................. 51

3.2.5.14 Teste de esterilidade ...................................................... 51

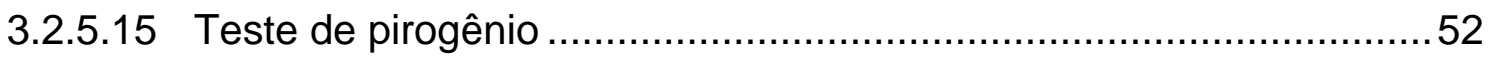

3.2.5.16 Polímeros e agregados.................................................... 52

3.2.5.17 Determinação da atividade anticórpica .................................... 52

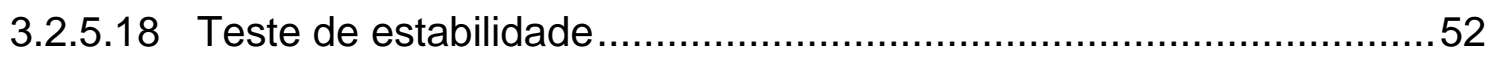

3.2.5.19 Validação dos procedimentos ............................................ 52

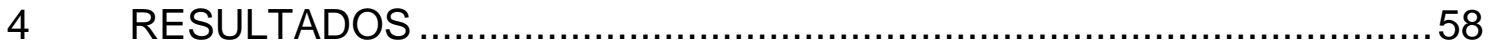

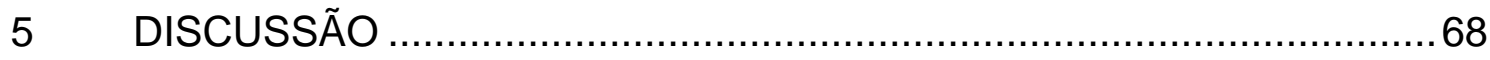

5.1 Concentrações de IgG e distribuição das subclasses lgG1, IgG2, IgG3

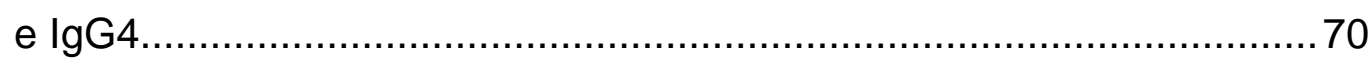

5.2 Qualidade das preparações de IgG......................................... 72

5.2 .1 Segurança da matéria-prima ....................................................... 72

5.2.2 Eficácia dos processos de fracionamento da IgG ............................79

5.2 .3 Eliminação de agentes patogênicos.......................................... 82

5.2.4 Espectro de atividades anticórpicas específicas ............................. 86

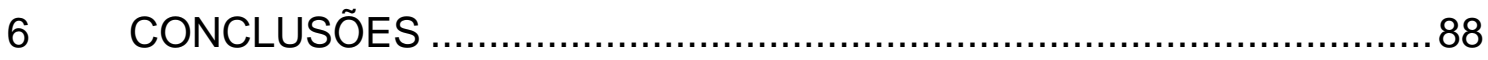

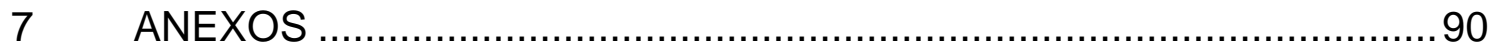

A. Descrição das Preparações de Imunoglobulina G ...........................91 91

B. Critérios Oficiais para Doação de Sangue - Portaria MS n¹376

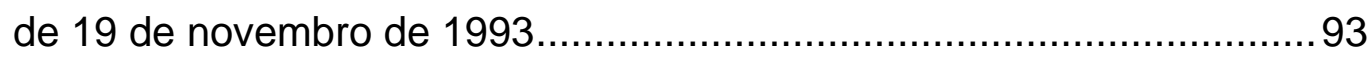




\section{LISTA DE FIGURAS}

Figura 1 Modelo da molécula de IgG 16

Figura 2 Diagrama das moléculas de IgG .21

Figura 3 Estruturas tridimensionais das subclasses da imunoglobulina $G$ $(\lg G)$ 23

Figura 4 Diagrama do processo de separação e purificação de plasma para obtenção de imunoglobulina da classe $\mathrm{G}$ por cromatografia em coluna

Figura 5 Área estéril, sistemas cromatográficos automatizados e tanques de aço inoxidáveis usados na separação e purificação de albumina e IgG humana 53

Figura 6 Sistema cromatográfico em coluna, contendo gel de troca iônica Q-Sepharose FF e CM-Sepharose FF, para purificação intermediária de IgG 
Figura 7 Sistema cromatográfico em coluna, contendo gel de filtração Sephacryl S-200 HR, para purificação final de albumina..............55

Figura 8 Sistema de filtros Peliicon Cassete 30.000 NMWL para concentração e ultrafiltração da solução de IgG 56

Figura 9 Albumina, IgG liofilizada, solução de IgG, fatores VIII e IX da coagulação fracionados por cromatografia em coluna a partir de plasma humano 57 


\section{LISTA DE TABELAS}

Tabela 1 Características básicas das subclasses da IgG humana 22

Tabela 2 Preparações de imunoglobulina da classe G (IgG) para uso humano por via intravenosa obtidas de misturas de plasma de variadas procedências e processadas por diferentes técnicas de separação

Tabela 3 Distribuição das subclasses IgG1, IgG2, IgG3 e lgG4 (\% do total de $\lg G$ ) e determinação quantitativa da concentração protéica (\%) em lotes de preparações de imunoglobulinas para uso humano por via de administração intravenosa 60

Tabela 4 Testes sorológicos realizados em preparações de IgG (uso humano) de variadas procedências para a determinação qualitativa dos anticorpos IgG contra os vírus: HIV (ELISA I e II); HTLV I/II (ELISA I e II; WB IV); HCV (ELISA I e III; WB II) e para determinação do material genético (DNA) do Parvovírus B19 (PCR) 62

Tabela 5 Determinação das frações antigênicas do vírus HTLV I/II por Western Blot que indicam soropositividade nas preparações de imunoglobulinas G para uso humano por via intravenosa 
Tabela 6 Testes sorológicos realizados em preparações de IgG (uso humano) de variadas procedências para determinação do antígeno de superfície AgHBs (ELISA II); determinação qualitativa dos anticorpos da classe IgG contra os vírus: HBV (ELISA (anti-HBs) I; (anti-HBc) II) ; HAV (ELISA anti-HAV (IgG) II; anti-HAV (IgM) II); determinação dos anticorpos anti-cardiolipina (VDRL V) e anti-T.pallidum (ELISA I e II, FTA-ABS VI)

Tabela 7 Atividade de anticorpos específicos antiestreptolisina O (ASLO); anti-rubéola; anti-toxoplasmose; anti-Chlamydia trach.; anti-citomegalovírus (CMV) e anti-herpes simples ( 1 e 2) em preparações de lgG, obtidas a partir de misturas de plasma humano de, no mínimo, 1.000 doadores 


\section{LISTA DE ABREVIATURAS}

\begin{tabular}{|c|c|}
\hline AgHBs & antígeno de superfície da hepatite B \\
\hline ALT & alanina aminotransferase \\
\hline anti-HAV & anti- vírus da hepatite $A$ \\
\hline anti-HBc & anti-antígeno do centro (core) da hepatite B \\
\hline anti-Hbs & anti-antígeno de superfície da hepatite B \\
\hline anti-HBV & anti- vírus da hepatite B \\
\hline anti-HCV & anti- vírus da hepatite C \\
\hline anti-HTLV & anti-vírus T- linfotrópico humano \\
\hline apud & citado por \\
\hline ASLO & Streptococcos pyogenes $\beta$-hemolítico do grupo A \\
\hline $\mathrm{BCIF}$ & bromocloro-indolifosfato \\
\hline C & porção ou região constante \\
\hline CDRs & regiões determinantes de complementariedade \\
\hline $\mathrm{CH}$ & cadeia pesada \\
\hline$C L$ & cadeia leve \\
\hline CLAE & cromatografia líquida de alta eficiência \\
\hline DNA & ácido desoxirribonucléico \\
\hline ed(s) & editor(es) \\
\hline EET & encefalopatia espongiforme transmissível \\
\hline ELISA & enzimaimunoensaio \\
\hline et al. & et allie (e outros) \\
\hline Fab & fragmento de ligação ao antígeno \\
\hline $\mathrm{FC}$ & fragmento cristalizável \\
\hline $\mathrm{HCV}$ & vírus da hepatite C \\
\hline HIV & vírus da imunodeficiência humana \\
\hline HTLV & $\begin{array}{l}\text { vírus da leucemia/linfoma de linfócitos } \mathrm{T} \text { do adulto e a } \\
\text { paraparesia espástica tropical ou mielopatia }\end{array}$ \\
\hline HAV & vírus da hepatite A \\
\hline HBV & vírus da hepatite B \\
\hline
\end{tabular}




$\begin{array}{ll}\text { IFI } & \text { imunofluorescência Indireta } \\ \text { Ig } & \text { imunoglobulina } \\ \text { IgA } & \text { imunoglobulina da classe A } \\ \text { IgD } & \text { imunoglobulina da classe D } \\ \text { IgE } & \text { imunoglobulina da classe } \mathrm{E} \\ \text { IgG } & \text { imunoglobulina da classe G } \\ \text { IgG* } & \text { imunoglobulina G marcada } \\ \text { IgM } & \text { imunoglobulina da classe M } \\ \text { iv } & \text { intravenosa } \\ \text { MHC } & \text { moléculas do complexo de histocompatibilidade principal } \\ \text { n० } & \text { número } \\ \text { NBT } & \text { nitrobluetetrazólio } \\ \text { nV-DCJ } & \text { nova variante da Doença de Creutzfeldt-Jakob } \\ \text { PCR } & \text { reação em cadeia da polimerase } \\ \text { RNA } & \text { ácido ribonucléico } \\ \text { SIDA/AIDS } & \text { síndrome da imunodeficiência adquirida } \\ \text { T. cruzi } & \text { Trypanosoma cruzi } \\ \text { T.pallidum } & \text { Treponema pallidum } \\ \text { TCD4+ } & \text { células T auxiliares } \\ \text { TCD8+ } & \text { células T citotóxicas ou citolíticas } \\ \text { TMB } & \text { tetrametilbenzidina } \\ \text { TTV } & \text { TTV vírus } \\ \text { USP } & \text { The United States Pharmacopoeia } \\ \text { UV } & \text { ultravioleta } \\ \text { V } & \text { porção ou região variável } \\ \text { VDRL } & \text { venereal disease research laboratory } \\ & \end{array}$




\section{LISTA DE SIGLAS}

$\begin{array}{ll}\text { CDC } & \text { Centers for Disease Control } \\ \text { MS } & \text { Ministério da Saúde } \\ \text { NIH } & \text { National Institutes of Health } \\ \text { OMS } & \text { Organização Mundial da Saúde } \\ \text { U.S.A. } & \text { United States of America } \\ \text { UK } & \text { United Kingdom } \\ \text { WHO } & \text { World Health Organization }\end{array}$




\section{LISTA DE SÍMBOLOS}

$\begin{array}{ll}{ }^{\circ} \mathrm{C} & \text { grau Celsus } \\ g & \text { unidade de centrifugação } \\ \mathrm{cm} & \text { centímetro } \\ \mathrm{mM} & \text { milimolar } \\ \mathrm{mS} / \mathrm{cm} & \text { milisiems por centímetro (unidade de condutividade) } \\ \mathrm{mg} & \text { miligrama } \\ \mathrm{g} & \text { grama } \\ \mathrm{g} / \mathrm{L} & \text { grama/Litro } \\ \mathrm{nm} & \text { nanometro } \\ \kappa & \text { cadeia leve kapa } \\ \lambda & \text { cadeia leve lambda } \\ \mathrm{KD} & \text { kilodalton } \\ \mu \mathrm{g} / \mathrm{L} & \text { micrograma/Litro } \\ \mu \mathrm{L} & \text { microLitro } \\ \mathrm{MgCl} & \text { cloreto de magnésio } \\ \mathrm{KCl} & \text { cloreto de potássio } \\ \mathrm{H} \mathrm{O}_{2} & \text { peróxido de hidrogênio } \\ \mathrm{W} / \mathrm{v} & \text { massa/volume }\end{array}$




\section{RESUMO}

BARNA, G.A.O Estudo comparativo "in vitro" entre preparações de imunoglobulina $\mathrm{G}$, para uso intravenoso, obtidas de plasma humano de variadas procedências e processadas por diferentes técnicas de separação. São Paulo, 2001. 117p. Tese (Doutorado) - Faculdade de Ciências Farmacêuticas, Universidade de São Paulo.

Os efeitos protetores da imunidade humoral são mediados por uma família de glicoproteínas chamadas anticorpos ou imunoglobulinas. As preparações de imunoglobulina $G$ ( $\lg G$ ) utilizadas em nosso país são importadas. No Brasil, a primeira preparação de IgG foi obtida na Fundação Pró-Sangue Hemocentro de São Paulo em 1993. O presente estudo avaliou preparações de IgG obtidas de misturas de plasma humano de variadas procedências, inclusive a preparação obtida no Brasil. Foram avaliados os seguintes parâmetros: concentração protéica, distribuição das subclasses da lgG, atividade de anticorpos específicos e segurança quanto a agentes patogênicos transmissíveis pelo sangue. Em algumas preparações, a concentração protéica de $\lg$ e a distribuição das suas subclasses estavam fora das especificações. As preparações apresentaram atividade de anticorpos específicos contra os vírus das hepatites $A$ e $B$, do herpes simples, da rubéola, citomegalovírus; contra a bactéria Streptococcos pyogenes $\beta$-hemolítico do grupo A e contra o parasita Toxoplasma gondii. A qualidade da matéria-prima utilizada em algumas das preparações de lgG não foi adequada em função de reações positivas para anticorpos contra alguns agentes infecciosos, tais como HTLV I/II, HAV, HBV, HCV e Treponema pallidum. Esse estudo também mostrou a necessidade de se implantar urgente um programa abrangente para avaliação das preparações de IgG a serem consumidas pela população brasileira. 


\section{SUMMARY}

BARNA, G.A.O "In vitro" comparative study between imunoglobulin G preparations, intravenous use, human plasma derived from different plasma sources and different separation techniques. São Paulo, 2001. 117p. Tese (Doutorado) - Faculdade de Ciências Farmacêuticas, Universidade de São Paulo.

A family of glycoproteins, which are called antibodies or immunoglobulins (IgG), mediates the protective effects of humoral immunity. In Brazil, the IgG for intravenous use are imported from other countries. The first Brazilian immunoglobulin $G$ for therapeutic use was obtained from human plasma at the Fundação Pró-Sangue Hemocentro de São Paulo. The present study was carried out to evaluate different preparations of IgG, human plasmaderived, include the preparation from Brazil. The protein concentration, IgG subclass distribution, specific antibody activities and safety regarding the main blood transmitted infectious diseases were analyzed. In some preparations, IgG protein concentration and subclass distribution were different from their specifications. Some preparations showed specific antibody activity against the following antigens: A and B hepatitis virus, rubella, herpes simplex virus, citomegalovirus, measles virus, Streptococcus pyogenes $\beta$-hemolytic group $\mathrm{A}$ and Toxoplasma gondii. The presence of antibodies against antigens such as HTLV I/II, HAV, HBV, HCV and Treponema pallidum has compromised the quality guaranty of the materialsource (plasma) used in some preparations. This study has also showed that a complete and effective program for the quality evaluation of IgG preparations used in Brazil is needed and should be urgently established. 
1. INTRODUÇÃO 
Os usos terapêuticos do sangue e derivados iniciaram-se no final do século passado e, desde então, importantes pesquisas promoveram significativos avanços na ciência transfusional. Uma delas foi a descoberta do sistema de grupos sangüíneos ABO feita por LANDSTEINER, em 1901, que através de experimentos, demonstrou que havia importantes diferenças antigênicas entre indivíduos da mesma espécie. Além disso, o contínuo desenvolvimento dos métodos de fracionamento do sangue tem possibilitado a obtenção de várias preparações, tais como albumina (BERGLÖF et al. 1983), imunoglobulinas (FERNANDES e LUNDBLAD, 1980) e fatores VIII (SMITH e BIDWELL, 1979) e IX (CHANDRA e BRUMMELHUIS, 1981) da coagulação sangüínea, com alto grau de pureza.

Desta forma, milhares de pacientes podem ser tratados com derivados de sangue humano processados industrialmente. Atualmente, pelo fato do Brasil não possuir nenhuma unidade industrial para obtenção das preparações, praticamente $100 \%$ desses produtos são importados. O Ministério da Saúde brasileiro gasta mais de $\mathrm{R} \$ 130$ milhões por ano com a importação de hemoderivados provenientes da Alemanha, Inglaterra, Áustria, França, Estados Unidos, além de outros países (dados oficiais do MS em 1999/2000).

A partir da década de 50 , os avanços conseguidos no campo da imunologia, associado ao desenvolvimento de imunoterapias seguras, permitiram à terapia de reposição com imunoglobulinas desempenhar grande importância na clínica médica, auxiliando na profilaxia e tratamento de várias doenças imunológicas (IUIS/WHO, 1988; JEFFERIS e KUMARARATNE, 1990).

Sabe-se que os efeitos protetores da imunidade humoral são mediados por uma família de glicoproteínas estruturalmente relacionadas, designada anticorpos ou imunoglobulinas (Ig), referindo-se à porção da fração gamaglobulínica que confere imunidade. O sangue contém grande quantidade dessas moléculas de glicoproteínas envolvidas nos processos de reconhecimento, ligação e eliminação de antígenos (ABBAS et al., 2000). Além disso, nas doenças autoimunes e aloimunes, o tratamento com 
imunoglobulina da classe $G$ (IgG) para uso humano por via intravenosa (iv) tem permitido consideráveis avanços quanto ao conhecimento dos mecanismos fisiopatológicos dessas doenças (NYDEGGER et al., 2000).

A IgG (iv), usada para fins terapêuticos, pode ser extraída e purificada a partir de misturas de plasma humano, de no mínimo 1000 doadores saudáveis, ativamente imunizados por vários aloantígenos, tais como vírus, bactérias e outros microorganismos (MORELL, 1986). Os processos de separação da IgG (iv) visam a obtenção de preparações com alto grau de pureza (conteúdo protéico acima de $90 \%$ e não superior a 110\%), com concentração protéica média de $70 \mathrm{~g} / \mathrm{L}$ (30 a 180g/L) e moléculas íntegras (formação de polímeros e agregados abaixo de 4\%), que possam garantir terapias mais eficazes (WHO, 1982).

Atualmente, dentre os processos industriais mais empregados para obtenção de preparações de imunoglobulina $G$ humana iv destacam-se: o método clássico de COHN et al. (1946), também conhecido como método de fracionamento do plasma com etanol a frio; a precipitação com polietilenoglicol (PEG) (WICKERHAUSER, 1971); a separação e purificação por técnica de cromatografia de troca iônica e gel-filtração (FRIESEN et al., 1983; SUOMELA et al., 1983), além do método misto, no qual utiliza-se etanol a frio durante a etapa inicial de separação e cromatografia em coluna na etapa final de purificação do produto (SUOMELA et al., 1983).

Contudo, em 1962, BARANDUM et al. observaram que as preparações de IgG fracionadas pelo método de COHN e administradas aos pacientes por via intravenosa causavam graves efeitos colaterais, tais como febre alta e várias reações alérgicas, devido à formação de polímeros ou à formação de agregados na solução de IgG. Os autores também concluíram que a presença dessas substâncias polimerizadas ou agregadas aumentava a atividade anticomplementar do anticorpo fracionado.

Em 1986, alguns estudos farmacológicos realizados por HÄSSIG demonstraram que, dependendo dos procedimentos de fracionamento, ocorria desnaturação ou alterações estruturais das moléculas de IgG ou de 
suas subclasses, tornando-as ineficazes para o uso terapêtico por via intravenosa.

Em indivíduos adultos saudáveis, a imunoglobulina da classe G constitui aproximadamente $75 \%$ do total das imunoglobulinas presentes no soro, sendo o restante constituído por outras classes de imunoglobulinas, tais como as imunoglobulinas das classes A, M, D e E (HAMILTON, 1987).

A IgG pode ser ainda subdividida nas subclasses IgG1, IgG2, IgG3 e IgG4 (BASSION, 1989; JEFFERIS e KUMARATNE, 1990). Cada uma das subclasses da lgG possui propriedades e funções biológicas específicas (LEFRÈRE et al., 1993). A Organização Mundial da Saúde (WHO, 1982; IUIS/WHO, 1988) faz relevantes considerações a respeito da importância da distribuição normal das subclasses da lgG nas preparações obtidas por fracionamento industrial.

Outra importante consideração ressalta que as preparações de $\lg G$ humana (iv) devem ser 100\% de seguras, pois diversos agentes patogênicos transmissíveis pelo sangue constituem grave problema de saúde pública no mundo todo (JEFFERIS et al., 1985; DODD et al., 1992; CARDOSO et al., 1996; ECHEVARRIA et al., 1996).

YAP et al. (1998) demonstraram a importância do conhecimento detalhado sobre os meios de detecção, de ação e de transmissão do príon, uma proteína mutante responsável por doenças cerebrais degenerativas, tal como a encefalopatia espongiforme transmissível (EET), também conhecida como doença da vaca louca. Em 1999, DROHAN e CERVENAKOVA inferiram a possibilidade desses príons estarem sendo transmitidos aos seres humanos através do sangue ou derivados.

A qualidade das preparações de lgG depende diretamente da rigorosa seleção dos doadores e da matéria-prima, dos processos de fracionamento e dos processos de inativação viral. No Brasil, ainda não foi realizado nenhum estudo demonstrando os riscos dessas contaminações nas preparações fracionadas do plasma e disponíveis para uso humano.

De modo complementar, não foi estabelecido o espectro de atividades de anticorpos específicos e necessários à nossa população. Assim, muitas 
das preparações de imunoglobulinas encontradas no mercado nacional podem não causar os efeitos terapêuticos desejados, simplesmente por não possuírem uma variedade ideal de atividades anticórpicas necessária aos indivíduos da população brasileira.

Atualmente, excetuando-se duas unidades pilotos instaladas, uma em São Paulo e outra em Recife, o país não possui unidades industriais capazes de processar grandes quantidades de plasma, necessárias à demanda por imunoglobulinas ou outros componentes derivados do sangue, tais como a albumina e os fatores da coagulação. Por isso, 100\% desses medicamentos são importados de várias partes do mundo: Europa, Ásia, Oceania, África e América do Norte e, em virtude do sigilo industrial, os dados completos de produção e controle de qualidade dos produtos são divulgados de forma insuficiente para uma análise qualitativa mais abrangente.

\subsection{Justificativas para o estudo}

O plasma, parte fluida do sangue, pode ser estocado por períodos que variam de um até três anos e, a partir dele, é possível separar importantes derivados sangüíneos como: a albumina, as imunoglobulinas e os fatores VIII e IX da coagulação sangüínea.

Existem diferentes técnicas de separação dessas proteínas, uma delas é o fracionamento do plasma com etanol a frio, também conhecido como método de Cohn. Outra técnica de fracionamento é uma associação entre o método de Cohn e a cromatografia em coluna. Algumas dessas proteínas também podem ser obtidas por engenharia genética. Atualmente, alguns dos principais fabricantes mundiais de hemoderivados defendem a total produção de albumina, imunoglobulinas e fatores da coagulação por bioengenharia, pois eles acreditam que, tecnicamente, os produtos obtidos não transmitem organismos patogênicos como vírus, bactérias ou os temidos príons, além de serem mais puros.

Porém, em quaisquer circunstâncias, deve sempre existir, por parte das autoridades de saúde pública e dos fabricantes, uma permanente 
preocupação em investigar-se a qualidade do sangue humano e derivados, para uso intravenoso, pois há uma extensa linha de pesquisa descrevendo casos de contaminações após a administração de imunoglobulinas e fatores da coagulação (CARDOSO et al., 1996; DODD et al., 1992; JEFFERIS et al., 1985; TANAKA et al., 1994).

WILL et al. (1996), além de outros pesquisadores, descreveram alguns casos clínicos nos quais, possivelmente, a encefalopatia espongiforme transmissível (EET), também conhecida como doença da vaca louca, teria conseguido atingir seres humanos, causando-Ihes uma nova variante da Doença de Creutzfeldt-Jakob (nv-DCJ).

Em estudos recentes, LAWLOR et al. (1999) mostraram elevados índices de transmissão do vírus da hepatite $\mathrm{C}$ em diferentes lotes de preparações de imunoglobulina anti-D. Os pesquisadores acreditam que essa elevada incidência é devida a uma etapa de inativação viral não específica ou ineficiente.

TAN et al. (1999) demonstraram, utilizando a determinação do material genético pela técnica de reação em cadeia da polimerase, a existência de um novo vírus não-envelopado denominado TT vírus (TTV), em concentrados de fator VIII e outros produtos derivados do plasma humano comercializados nos Estados Unidos.

Atualmente, há uma grande mobilização das comunidades científicas e de órgãos mundiais de saúde para que rigorosos testes sorológicos sejam realizados em todas as amostras de sangue doado e em todos os produtos beneficiados a partir dele (LAWLOR et al., 1999). No Brasil, não foi realizado nenhum trabalho demonstrando os riscos de contaminações em produtos fracionados do plasma e disponíveis para uso em humanos.

Adicionalmente, a Organização Mundial da Saúde (WHO, 1982; IUIS/WHO, 1988) faz relevantes considerações a respeito da importância da distribuição normal das subclasses da IgG. Concentrações séricas alteradas de uma ou mais subclasses podem estar associadas a certas condições clínicas como: doenças autoimunes e hipogamaglobulinemias (SODERSTROM et al., 1986). 
SHAKIB e STANWORTH (1980 a,b) e SHIELD et al. (1992) demonstraram que também a hipergamaglobulinemia não exclui deficiências das subclasses da IgG.

Segundo observações feitas por especialistas da Organização Mundial da Saúde (COMITE DE ESPECIALISTAS - OMS, 1994), sucessivas etapas de fracionamento do plasma podem reduzir as concentrações das subclasses IgG1, IgG2, IgG3 e IgG4 nas preparações finais. Os diferentes procedimentos de inativação e/ou eliminação viral também podem colaborar para a redução nos níveis das subclasses e, consequentemente, as preparações de IgG humana podem ter comprometido sua eficácia nas terapêuticas de reposição com imunoglobulinas.

Outra questão abordada pelos órgãos mundiais de saúde, diz respeito à mistura ou "pool" de plasma humano, matéria-prima essencial para a obtenção da imunoglobulina $\mathrm{G}$ usada na profilaxia e tratamento de diversas infecções (WHO, 1982; IUIS/WHO, 1988). Essa mistura deve ser proveniente de, no mínimo, 1000 doadores saudáveis a fim de se garantir um produto final de anticorpos com um amplo espectro de especificidades. Assim, de acordo com os estímulos antigênicos aos quais sua população está submetida, cada país deve estabelecer (COMITE DE ESPECIALISTASOMS, 1994; EUROPEAN PHARMACOPOEIA, 1997) o espectro de especificidades necessário nas preparações de IgG.

É importante ressaltar que, no Brasil, tais especificações não foram ainda estabelecidas e muitas das preparações disponíveis no mercado nacional podem não causar efeitos terapêuticos satisfatórios.

Além da albumina humana (TANAKA et al., 1996), a Fundação PróSangue Hemocentro de São Paulo tem fracionado, em caráter experimental, imunoglobulina $G$ humana para uso intravenoso (TANAKA et al., 1993; TANAKA et al., 1994), utilizando plasma de doadores voluntários coletado no banco de sangue da própria Instituição.

Nosso país não possui ainda nenhuma unidade industrial capaz de fracionar e controlar grandes quantidades de plasma para suprir toda demanda por componentes protéicos fracionados do sangue e, por isso, 
100\% desses produtos são importados de várias partes do mundo como: Europa, Ásia, Oceania, África e América do Norte. Além disso, hoje, o Brasil também não possui nenhum programa nacional para controle da qualidade de todos os produtos derivados de sangue, utilizados em diversos tratamentos clínicos. Por outro lado, praticamente nenhum centro de excelência científica desenvolve, no país, pesquisas avançadas em fracionamento de proteínas derivadas do sangue para uso em humanos.

Assim, acreditamos na oportunidade de realização do presente estudo comparativo entre preparações de IgG iv de variadas procedências, muito utilizadas em terapias de reposição, a fim de investigarmos a qualidade e a segurança desses produtos.

\subsection{Objetivos}

Avaliar "in vitro" a qualidade de preparações de IgG, para uso humano por via intravenosa (iv), fracionadas a partir de misturas de plasma humano de variadas procedências populacionais, disponíveis no mercado nacional.

> Determinar "in vitro" a distribuição das subclasses IgG1, IgG2, IgG3 e IgG4 nessas preparações.

> Investigar as respostas protetoras dessas preparações determinando "in vitro" a atividade de anticorpos específicos para os vírus do herpes simples (1 e 2), da rubéola, citomegalovírus; para as bactérias Streptococcos pyogenes $\beta$-hemolítico do grupo A (ASLO) e Chlamydia trachomatis; para o parasita Toxoplasma gondii.

> Investigar "in vitro" a efetiva segurança dessas preparações, determinando a presença do antígeno de superfície do vírus $B ; a$ presença de anticorpos para os agentes causadores das hepatites $A, B$ e $C$, da imunodeficiência humana (SIDA/AIDS), da leucemia/linfoma dos linfócitos $T$ do adulto e da paraparesia espástica tropical ou mielopatia, da sífilis e a presença de material genético (DNA) do Parvovírus B-19. 
2. REVISÃO DA LITERATURA 


\subsection{Sistema imunológico}

O termo imunidade é derivado da palavra em latim "immunitas", que se referia à isenção de vários deveres cívicos e de processos legais oferecida aos senadores romanos durante seus mandatos. Historicamente, imunidade significava proteção contra doenças e, mais especificamente, contra doenças infecciosas (ABBAS et al., 1994). O sistema imunológico ou imune é constituído de órgãos, tecidos, células e moléculas que interagem para proteger o organismo. Através do sistema imunológico, o organismo tem a capacidade de reconhecer substâncias estranhas a ele, tais como microorganismos patogênicos ou quaisquer outras substâncias nocivas, apresentando uma resposta de eliminação dessas substâncias estranhas, ou simplesmente, uma resposta imune (BASSION, 1989; ABBAS et al., 2000). Sabe-se que, muitos dos mecanismos de resistência às infecções estão envolvidos na resposta do indivíduo a substâncias estranhas nãoinfecciosas. Portanto, como uma definição mais abrangente e moderna, a imunidade é uma reação a substâncias estranhas, não só a micróbios, bem como a macromoléculas, tais como proteínas e polissacarídeos, sem, contudo implicar uma conseqüência fisiológica ou patológica a tal reação (ABBAS et al., 2000).

De maneira geral, indivíduos sadios são protegidos contra microrganismos por meio de variados mecanismos e, um dos mecanismos protetores é a imunidade inata (ou natural, ou nativa). Os principais componentes desse mecanismo de imunidade são: 1) as barreiras físicas e químicas, tais como os epitélios e as substâncias antimicrobianas produzidas nas superfícies epiteliais; 2) as proteínas sangüíneas, incluindo membros do sistema do complemento e outros mediadores da inflamação; e 3) as células fagocitárias (neutrófilos, macrófagos) e outros leucócitos, tais como as células "natural killers". Em contraste à imunidade inata, existem mecanismos de defesa mais evoluídos que aumentam de magnitude e de capacidade defensiva quando estimulados pela exposição repetida a agentes infecciosos. Esta forma de imunidade, que evolui como uma 
resposta a cada sucessiva infecção, é chamada de imunidade adquirida, ou imunidade específica devido à sua capacidade em distinguir diferentes microrganismos. Os componentes da imunidade específica são os linfócitos e seus produtos, os anticorpos. As substâncias estranhas, tais como microrganismos ou substâncias não infecciosas, que induzem respostas imunes específicas, ou são os alvos dessas respostas, são chamadas antígenos. Baseadas nos componentes do sistema imune que funcionam como mediadores, as respostas imunes específicas são classificadas em dois tipos: 1) Imunidade humoral, que é mediada por moléculas do sangue, tais como os anticorpos; 2) Imunidade celular, que é mediada por células chamada linfócitos T (ABBAS et al., 2000).

As células da imunidade humoral são os linfócitos $B$, que respondem aos antígenos estranhos por meio do desenvolvimento de células produtoras de anticorpos, enquanto que os mediadores da imunidade celular são os linfócitos T (ABBAS et al., 2000). O principal mecanismo de defesa contra os microrganismos extracelulares e as toxinas por eles secretadas é a imunidade humoral, porque os anticorpos podem ligar-se a esses elementos e ajudar na sua eliminação. Ao contrário, os microrganismos intracelulares, tais como vírus e bactérias, sobrevivem e proliferam-se dentro dos fagócitos e dentro de outras células do hospedeiro, onde se tornam inacessíveis aos anticorpos circulantes. A defesa contra as infecções causadas por esses agentes está a cargo da imunidade celular, cuja função é promover a destruição dos microrganismos localizados nos fagócitos ou lisar as células infectadas. Desta forma, as etapas de respostas imunes específicas podem ser divididas em: (1) fase de reconhecimento; (2) fase de ativação e (3) fase efetora (ABBAS et al., 2000).

A fase de reconhecimento consiste na ligação dos antígenos estranhos a receptores específicos dos linfócitos maduros, existentes antes da exposição ao antígeno. Os linfócitos B, células da imunidade humoral, expressam moléculas de anticorpos sobre suas superfícies, que podem se ligar às proteínas estranhas, aos polissacarídeos, aos lipídios ou a outras substâncias químicas nas formas extracelulares ou associadas às células. A 
segunda classe de linfócitos é formada pelos linfócitos T, cujos precursores originam-se na medula óssea e depois migram para o timo onde amadurecem. Os linfócitos T subdividem-se em populações funcionalmente distintas, as células $\mathrm{T}$ auxiliares (TCD4+) e as células $\mathrm{T}$ citotóxicas ou citolíticas (TCD8+). Os TCD8+ são os responsáveis, principalmente, pela imunidade mediada pela célula; expressam receptores que reconhecem os antígenos protéicos apenas no contexto das moléculas do complexo de histocompatibilidade (MHC) (AMMANN, 1994).

A fase de ativação consiste na seqüência de eventos induzida nos linfócitos em conseqüência do reconhecimento de um antígeno específico. Os linfócitos B, estimulados por antígenos, diferenciam-se em plasmócitos, que são células secretoras de anticorpos e, esses anticorpos ligam-se aos antígenos, desencadeando os mecanismos de eliminação. Alguns linfócitos TCD4+ diferenciam-se em células capazes de ativar os fagócitos, que também ajudam a eliminar microrganismos intracelulares. Os linfócitos TCD8+ lisam diretamente as células que estão produzindo antígenos estranhos, tais como as proteínas virais (ABBAS et al., 2000).

A fase efetora consiste na eliminação do antígeno pelos linfócitos especificamente ativados. Um dos mecanismos de defesa na fase efetora utiliza anticorpos que se ligam a antígenos estranhos e facilitam sua fagocitose pelos neutrófilos e fagócitos mononucleares presentes no sangue. Os anticorpos ativam também um sistema de proteínas plasmáticas designado complemento, que participa na lise e na fagocitose dos microrganismos. Outro importante mecanismo da fase efetora processa-se com os linfócitos $T$ ativados que secretam citocinas, as quais facilitam as funções dos fagócitos e estimulam os processos inflamatórios (ABBAS et al., 2000).

\subsection{Antígenos}

Os antígenos combinam-se de modo específico com os anticorpos e são definidos como substâncias imunógenas de uma resposta imune. A resposta imunológica produzida pode ser um anticorpo (resposta humoral) 
ou a produção de células sensibilizadas (resposta celular). Mais freqüentemente, ambas as respostas, humoral e celular, são estimuladas (GOODMAN, 1994a; MOLLISON et al., 1997).

Os primeiros antígenos investigados foram de bactérias e hemácias. As estruturas dos complexos macromoleculares são formadas por diferentes proteínas, carboidratos e lipídeos. Porém, sabe-se que polissacarídeos, glicolípides, ácidos nucleicos e polinucleotídeos são também substâncias capazes de induzir uma resposta imunológica. Não há um padrão absoluto requerido, mas o tamanho da molécula exerce considerável importância na determinação da imunogenicidade. Sabe-se que os mais potentes antígenos são macromoléculas com pesos moleculares acima de 100.000 daltons. As substâncias com baixo peso molecular (abaixo de 10.000daltons) são denominadas haptenos e podem induzir uma resposta imune apenas quando acoplados a outras moléculas imunogênicas com alto peso molecular, denominadas moléculas carreadoras. Muitas substâncias podem agir como haptenos, tais como monossacarídeos, lipídeos, pequenos peptídeos, hormônios, como o adrenocorticotrópico (ACTH), prostaglandinas e drogas, tais como barbitúricos e sulfonamidas. A molécula de antígeno deve exibir um certo grau de complexidade química para ser considerada imunogênica. O aumento da imunogenicidade é proporcional ao aumento da complexidade das moléculas, por exemplo, a adição de resíduos de aminoácidos aromáticos, tais como tirosina, a copolímeros de aminoácidos sintéticos aumenta a imunogenicidade da molécula (BASSION, 1989; MOLLISON et al., 1997).

Determinante antigênico é a menor porção da molécula de um antígeno que interage com o sítio de combinação de anticorpos ou com os receptores para antígenos nos linfócitos T. Um antígeno pode conter mais de um tipo de determinante antigênico e o número de determinantes por antígeno varia de acordo com o tamanho e complexidade da molécula (ABBAS et al., 2000). 


\section{$2.3 \quad$ Anticorpos}

Sabe-se que os efeitos protetores da imunidade humoral são mediados por uma família de glicoproteínas, estruturalmente relacionadas, chamados anticorpos. As glicoproteínas do plasma ou do soro podem ser separadas em albumina e globulinas devido às solubilidades características de cada classe de moléculas e, podem ser subdivididas pela sua capacidade de migração em um campo elétrico. Outra designação conhecida para anticorpo é imunoglobulina $(\mathrm{Ig})$, referência direta à porção da fração gamaglobulínica que confere imunidade (ABBAS et al., 1994; MOLLISON et al., 1997).

Os anticorpos iniciam seus efeitos protetores assim que se ligam aos antígenos. Os anticorpos, como também as moléculas do MHC principal e os receptores antigênicos dos linfócitos $T$ constituem as três classes de moléculas usadas pelo sistema imunológico específico para o reconhecimento de antígenos.

Os anticorpos são produzidos pelos linfócitos B e plasmócitos (formas diferenciadas das células B). Encontram-se ligados à membrana dos linfócitos B e funcionam como receptores para antígenos dessas células. Os anticorpos produzidos pelos plasmócitos são liberados, posteriormente, para a circulação geral (GOODMAN, 1991; PARSLOW, 1994). Os anticorpos foram, inicialmente, isolados do plasma, mas podem ser também encontrados em outros locais. Eles são encontrados ligados a membranas no interior dos compartimentos citoplasmáticos (retículo endoplasmático e aparelho de Golgi) e na superfície dos linfócitos B, as únicas células que sintetizam moléculas de anticorpo. Os anticorpos estão presentes no plasma e, em menor proporção, no líquido intersticial dos tecidos. Os anticorpos também são ligados à superfície de certas células efetoras imunes, tais como fagócitos mononucleares, células "natural killer" (NK) e mastócitos pela ligação da região (fragmento) cristalizável $(F c)$ a receptores para $F c$ presentes nas imunoglobulinas da classe G (IgG) e E (IgE). Os anticorpos 
estão presentes ainda nos fluidos de secreção, tais como saliva muco e leite (GOODMAN, 1991; ABBAS et al., 2000).

\subsubsection{Estrutura básica molecular dos anticorpos}

Todas as moléculas de anticorpos possuem estrutura global semelhante, o que explica certas características físico-químicas comuns, tais como carga elétrica e solubilidade. Todos os anticorpos têm uma estrutura central comum composta de duas cadeias leves idênticas (cadeias $L$ cada uma com cerca de 24 quilodaltons - kD) e duas cadeias pesadas idênticas (cadeias $\mathrm{H}$ com cerca de 55 a $70 \mathrm{kD}$ ) de aminoácidos unidas por ligações não-covalentes e ligações covalentes intercadeias, tais como pontes dissulfídricas (-S-S-) entre a parte carboxiterminal da cadeia leve e o domínio $\mathrm{CH} 1$ da cadeia pesada. Dependendo da enzima usada para a clivagem da molécula, a cisão ocorre à esquerda (pela ação da papaína) ou à direita (pela ação da pepsina) da ponte -S-S-, resultando fragmentos de ligação ao antígeno (Fab) (3,5 S) ou (Fab') $)_{2}$ (5 S) (Figura 1). Pequenas variações da seqüência de aminoácidos da cadeia $H$ condicionam os alótipos $\mathrm{Gm}$ e os alótipos de IgG são a conseqüência de pequenas variações da porção constante da cadeia pesada. A IgE possui um domínio a mais $(\mathrm{CH} 4)$, o mesmo ocorrendo com a cadeia pesada da IgM e da IgD (CALICH, 1988). Tanto as cadeias leves quanto as pesadas contêm uma série repetitiva de unidades homólogas, cada uma com aproximadamente 110 resíduos de aminoácidos que se enovelam independentemente em um motivo globular comum designado domínio de imunoglobulina (MOLLISON et al., 1997; ABBAS et al., 2000). 


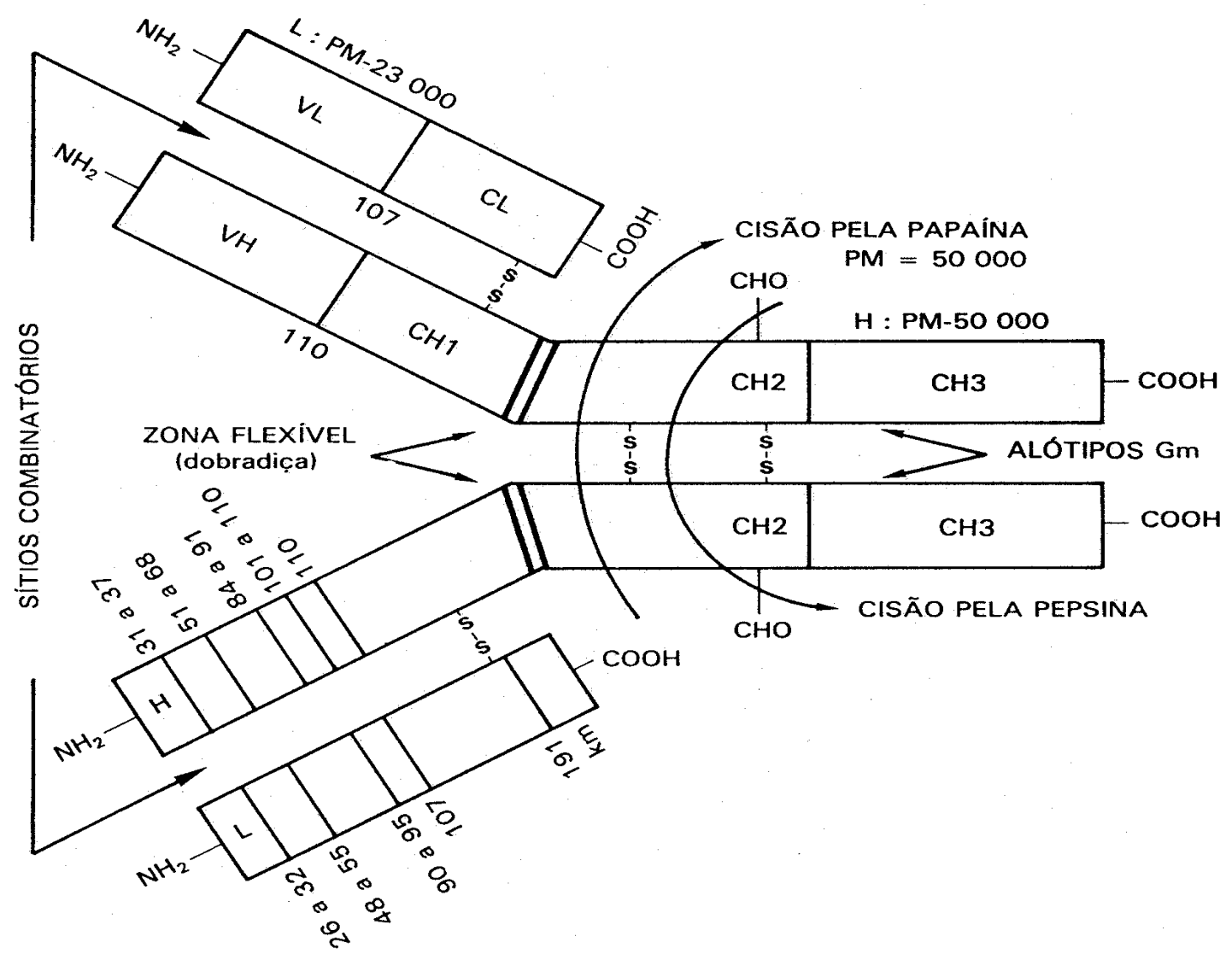

apud: CALICH, V.L.G. Imuneglobulinas. In: CALICH, V.L.G. e VAZ, C.A.C., eds. Imunologia básica. São Paulo: Artes Médicas, 1988. p.68.

Figura 1 - Modelo da molécula de IgG formada pela união de duas cadeias leves e duas pesadas. VL e CL são as porções variável e constante, respectivamente, da cadeia leve; VH é a porção variável da cadeia pesada e $\mathrm{CH} 1, \mathrm{CH} 2$ e CH3 são as porções constantes da cadeia $\mathrm{H}$.

O padrão básico da associação de cadeias em todas as moléculas de anticorpo é que cada cadeia leve prende-se a uma cadeia pesada e cada cadeia pesada prende-se a uma outra cadeia pesada. No coelho, alguns estudos de estrutura da imunoglobulina, após clivagem enzimática com papaína, revelaram que a molécula da IgG pode ser separada em três partes protéicas distintas de tamanhos aproximadamente iguais. Duas das partes 
são idênticas entre si e consistem de uma cadeia leve intacta associada a um fragmento $\mathrm{V}_{\mathrm{H}}-\mathrm{C} \gamma 1$ da cadeia pesada. Cada um desses fragmentos possui a capacidade de ligação da molécula de imunoglobulina intacta ao antígeno e são chamados fragmentos Fab (fragmento de ligação ao antígeno). O terceiro fragmento contém fragmentos idênticos da cadeia pesada $\gamma$, compostos dos domínios C $\gamma 2$ e C $\gamma 3$. Essa parte da IgG tem uma propensão à auto-associação e à cristalização e, por essa razão, é chamado de Fc (fragmento cristalizável) (GOODMAN, 1991; ABBAS et al., 2000). A tendência de cristalização das regiões $\mathrm{Fc}$ reflete a presença de seqüências comuns de aminoácidos dos domínios $C_{\gamma} 2$ e $C_{\gamma} 3$ compartilhados por todos os anticorpos do mesmo subtipo. Importantes funções efetoras das imunoglobulinas são mediadas pelo fragmento $\mathrm{Fc}$, que são específicos para os diferentes isótipos. De fato, a organização básica da molécula de lgG, deduzida sobre a IgG do coelho, é comum a todas as moléculas IgG de todos os isótipos e de todas as espécies. As funções efetoras mediadas pelo fragmento Fc incluem: ativação do complemento pela lgG e IgM; opsonização pela IgG para aceleração da fagocitose; citotoxicidade mediada por células e dependente de anticorpo IgG, IgE e IgA; hipersensibilidade imediata desencadeada por IgE; imunidade na mucosa mediada por IgA; imunidade neonatal mediada por IgG materna e inibição por retroalimentação das respostas imunes mediadas por IgG (ABBAS et al., 1994, MOLLISON et al., 1997).

Apesar de sua semelhança geral, as moléculas do anticorpo podem ser divididas em classes e subclasses distintas, que diferem quanto às características físico-químicas, tais como composição, tamanho, carga elétrica, solubilidade e nas funções imunes (GOODMAN, 1991; WORDELL, 1991). As classes de moléculas de anticorpos são também designadas isótipos e, particularmente no homem, são definidas como: $\lg A, \lg D, \lg E$, $\lg G$ e IgM. Os isótipos IgA e IgG podem ser ainda subdivididos em subclasses estreitamente relacionadas, respectivamente IgA1, IgA2 e IgG1, IgG2, IgG3 e IgG4 (GREY e KUNKEL, 1964; TERRY e FAHEY, 1964). Todas as imunoglobulinas são compostas de $82 \%$ a $96 \%$ de polipeptídeos e de $4 \%$ a 
8\% de carboidratos (BASSION, 1989; MOLLISON et al., 1997; ABBAS et al., 2000). As moléculas de imunoglobulinas possuem uma estrutura com quatro cadeias polipeptídicas. A grande variedade de estruturas moleculares responde pela extraordinária especificidade de anticorpos para os antígenos, porque cada diferença de aminoácido pode produzir uma diferença na ligação do anticorpo com o antígeno (ABBAS et al., 2000).

O domínio N-terminal é chamado de região variável (região V) para distingui-lo das regiões constantes (região $\mathrm{C}$ ), mais conservadas e que ocupam o restante da cadeia polipeptídica. As três áreas altamente divergentes dentro das regiões $\mathrm{V}$ e $\mathrm{C}$ são chamadas regiões hipervariáveis. Em uma molécula de imunoglobulina íntegra, as três regiões hipervariáveis de uma cadeia leve e as três de uma cadeia pesada podem ocupar conjuntamente um espaço tridimensional para formar uma superfície de ligação para o antígeno. Nos anticorpos da classe $\lg G$, IgA e IgD, as regiões constantes mais curtas formam três domínios lg e essas regiões hipervariáveis são também chamadas de regiões determinantes de complementaridade. Em outras palavras, as regiões $\mathrm{V}$ das cadeias pesadas e leves respondem pelo reconhecimento do antígeno e, a região $C$ das cadeias pesadas são responsáveis pelo início das funções efetoras (ABBAS et al., 2000).

As cadeias pesadas $(\mathrm{H})$ de todas as moléculas de imunoglobulina dentro de um isótipo ou de uma subclasse compartilham extensas regiões de identidade na seqüência dos aminoácidos. As cadeias pesadas são designadas pelas letras do alfabeto grego gama $(\gamma)$, alfa $(\alpha)$, mu $(\mu)$, delta $(\delta)$ e epsilon $(\varepsilon)$ e têm variações nos seus pesos moleculares. Gama, alfa e delta são compostas de três regiões constantes. As seqüências de aminoácidos da cadeia pesada, que são compartilhadas pelas imunoglobulinas dentro de uma mesma classe, são responsáveis tanto pelas propriedades físico-químicas comuns como pelas propriedades antigênicas. Além disso, as regiões compartilhadas das cadeias pesadas fornecem membros de cada isótipo com capacidades comuns para se ligar a certos receptores da superfície celular ou a outras macromoléculas, tais como as 
moléculas do complemento e, assim, ativar funções efetoras imunes específicas (ABBAS et al., 2000).

Há dois tipos de cadeias leves (L) na molécula de imunoglobulina,

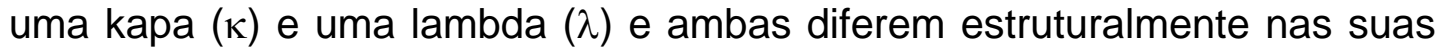
seqüências de aminoácidos das regiões constantes carboxiterminal. Uma determinada molécula de anticorpo, dentro de uma classe ou de uma subclasse, tem sempre duas cadeias leves idênticas kapa ou duas cadeias leves idênticas lambda. No homem, os anticorpos com cadeia leve $\kappa$ e $\lambda$ estão presentes numa proporção aproximada de 2:1. Não existem diferenças conhecidas de função entre os anticorpos contendo $\kappa$ e os contendo $\lambda$ (ABBAS et al., 2000).

Uma vez que toda molécula contém pelo menos duas cadeias leves e duas pesadas, toda molécula de Ig contém pelo menos dois sítios de ligação de antígenos, cada um formado por um par de domínios $\mathrm{V}_{\mathrm{H}} \mathrm{e} \mathrm{V}_{\mathrm{L}}$. Muitas moléculas de Ig podem orientar esses locais de ligação, de modo que duas moléculas de antígenos em uma superfície plana, por exemplo, uma célula, podem ser lançados de uma vez. Essa flexibilidade é conferida pela região da dobradiça (região Hinge). Observam-se diferenças significativas entre as regiões constantes das subclasses da IgG concentradas na região da dobradiça (ABBAS et al., 2000).

\subsubsection{Imunoglobulina da classe M (IgM)}

A IgM representa aproximadamente $10 \%$ de todos os anticorpos e é a única imunoglobulina com estrutura molecular pentamérica composta de cinco unidades básicas ligadas entre si pelos fragmentos Fc (WORDELL et al., 1991; GOODMAN e PARSLOW, 1994b). Os cinco monômeros de imunoglobulina estão unidos por ligações dissulfídricas entre as cadeias H das subunidades. Adicionalmente, a molécula de IgM (pentamérica) contém uma cadeia polipeptídica designada $\mathrm{J}$, que auxilia na manutenção da estabilidade da molécula. Esta cadeia J é uma glicoproteína pequena (PM 15.000 daltons), que está ligada covalentemente às cadeias $\mathrm{H}$ da molécula de imunoglobulina. A IgM é a primeira classe de anticorpo a ser produzida 
ativamente em recém-nascidos. É também a primeira Ig a ser detectada durante uma resposta imune após uma estimulação antigênica primária, característica de anticorpo de fase aguda (BASSION, 1989).

\subsubsection{Imunoglobulina da classe A $(\lg A)$}

A IgA representa aproximadamente $15 \%$ a $20 \%$ dos anticorpos e está presente em maior concentração em secreções externas, tais como saliva, lágrima, leite materno, colostro e suor. Nas moléculas de IgA secretadas existem seqüências não globulares adicionais estendidas no lado carboxiterminal do último domínio $C_{H}$. Essas extensões são chamadas peças caudais e contribuem para as interações intermoleculares que resultam na formação de moléculas de Ig multiméricas. Especificamente, a IgA pode formar dímeros contendo quatro cadeias pesadas e quatro cadeias leves. A IgA multimérica, assim como a IgM, também encerram um polipeptídeo adicional de 15kD chamado cadeia J, ligadas por pontes dissulfídricas a peças caudais, que estabiliza o multímero (GOODMAN, 1991).

\subsubsection{Imunoglobulina da classe $\mathrm{D}(\operatorname{IgD})$}

A IgD é um monômero de imunoglobulina e está presente no soro humano em quantidades ínfimas. As células $B$ imaturas expressam IgM. As células $B$ maduras, na ausência de prévia estimulação, expressam tanto IgM quanto IgD. Assim, essas imunoglobulinas, expressas nas superfícies da membrana dos linfócitos $B$, funcionam como receptores para antígenos nessas células. As células $B$ de memória podem expressar qualquer isótipo. Porém, a principal função da imunoglobulina $D$ não está ainda muito bem elucidada. Alguns estudos consideram que essa Ig pode ser uma proteína vestigial de um sistema imune mais primitivo (GOODMAN, 1991).

\subsubsection{Imunoglobulina da classe E (IgE)}

A IgE é também uma imunoglobulina monomérica. Ela está presente no soro em baixas concentrações, representando cerca de $1 \%$ dos 
anticorpos totais. A IgE, que se liga a receptores de basófilos e mastócitos através de sua porção Fc. Devido à alta afinidade de ligação, os receptores Fc são ocupados pelo monômero IgE na ausência de antígeno. A introdução de antígeno específico causa agregação de moléculas IgE ligadas aos seus receptores. Esse agrupamento, por sua vez, faz com que o mastócito libere mediadores inflamatórios e vasoativos, por exemplo, histamina, dos grânulos de armazenamento pré-formados. A conseqüência da liberação desses mediadores é uma resposta vascular e inflamatória denominada anafilaxia (GOODMAN e PARSLOW, 1994b).

\subsubsection{Imunoglobulina da classe G (IgG)}

As moléculas de IgG são monômeros da subunidade básica da imunoglobulina. Essa Ig é composta de duas cadeias leves kapa, ou duas lambda, e duas cadeias pesadas gama (Figura 2):
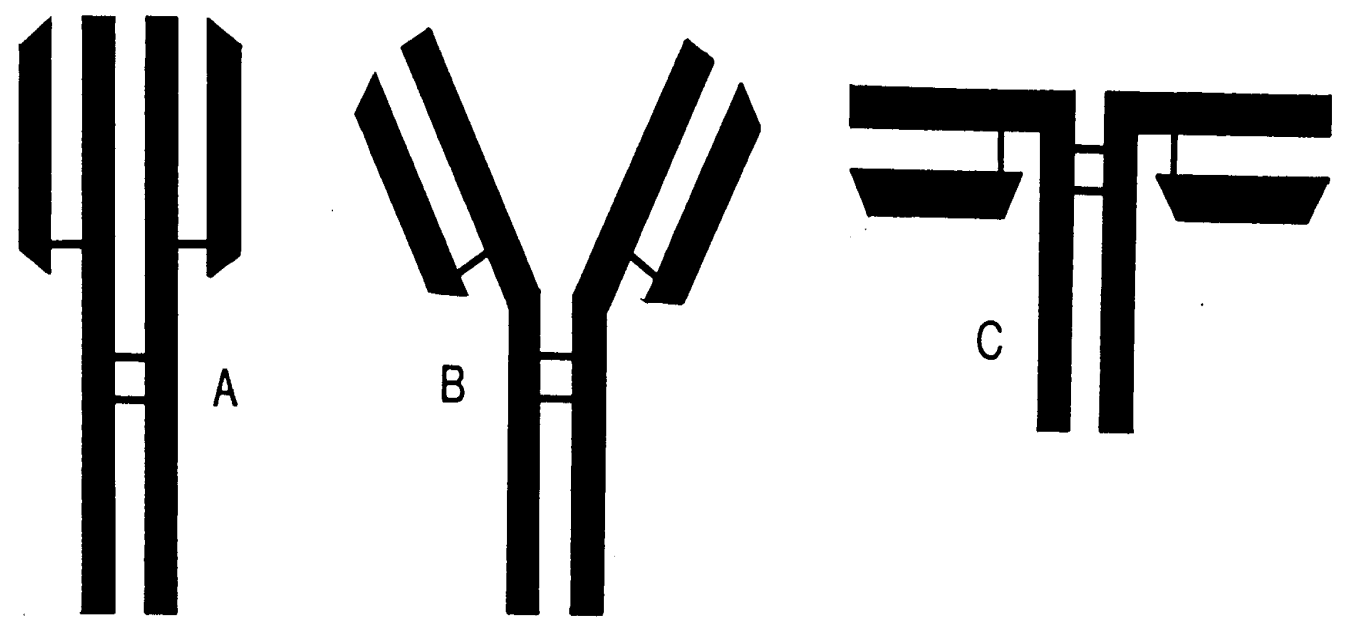

Figura 2 - Diagramas das moléculas de IgG. Os sítios combinatórios estão muito próximos na IgG livre (A) e podem afastar-se para alcançar determinantes mais afastados (B), atingindo o afastamento máximo de $180^{\circ}$ (C) (apud: CALICH, V.L.G. Imuneglobulinas. In: CALICH, V.L.G. , VAZ, C.A.C., eds. Imunologia básica. Artes Médicas, São Paulo, 1988. p. 78) 
Aproximadamente, 70 a $75 \%$ das imunoglobulinas totais no plasma correspondem à classe $\mathrm{G}$, com concentração média de 12g/L (GOODMAN e PARSLOW, 1994b; MOLLISON et al., 1997). Suas principais funções efetoras são: a capacidade de ativar o complemento através da via clássica; opsonização para aceleração da fagocitose; citotoxicidade; imunidade neonatal mediada pela IgG materna e inibição por retroalimentação das respostas imunes. No homem, a imunoglobulina $G$ pode ser subdividida em subclasses estreitamente relacionadas: IgG1, IgG2, IgG3 e IgG4 e, no soro normal de um indivíduo adulto, as distribuições médias (\%) dessas subclasses são: IgG1 60-70\%; IgG2 14-20\%; IgG3 4-8\% e IgG4 2-6\% (Tabela 1) (BASSION, 1989; JEFFERIS e KUMARATNE, 1990; MOLLISON et al., 1997).

Tabela 1 Características básicas das subclasses da IgG humana

\begin{tabular}{|c|c|c|c|c|c|c|}
\hline $\begin{array}{c}\text { Sub- } \\
\text { classes }\end{array}$ & $\begin{array}{c}\text { Peso } \\
\text { Molecular }\end{array}$ & $\begin{array}{l}\text { Concentração } \\
\text { média no soro } \\
(\mathrm{mg} / \mathrm{L})\end{array}$ & $\begin{array}{l}\text { Distribuição } \\
\text { Média (\%) }\end{array}$ & $\begin{array}{c}\text { Meia- } \\
\text { vida } \\
\text { biológica } \\
\text { (dias) }\end{array}$ & $\begin{array}{c}\text { Fixação } \\
\text { De } \\
\text { Comple- } \\
\text { Mento }\end{array}$ & $\begin{array}{l}\text { Transporte } \\
\text { placentário }\end{array}$ \\
\hline $\lg G 1$ & 146.000 & 8.400 & 65 & 25 & ++ & + \\
\hline $\lg G 2$ & 146.000 & 2.400 & 17 & 23 & + & \pm \\
\hline $\lg G 3$ & 165.000 & 800 & 6 & 9 & +++ & + \\
\hline $\lg G 4$ & 146.000 & 400 & 4 & 25 & - & + \\
\hline
\end{tabular}


O comprimento e a flexibilidade das regiões de dobradiças diferem significativamente entre as subclasses de IgG porque a maioria das diferenças de seqüências dos aminoácidos, entre as quatros subclasses, está localizada nas regiões de dobradiças. Em grande parte, essas diferenças de seqüência induzem à existência de distintas formas globulares entre as subclasses de IgG (Figura 3).

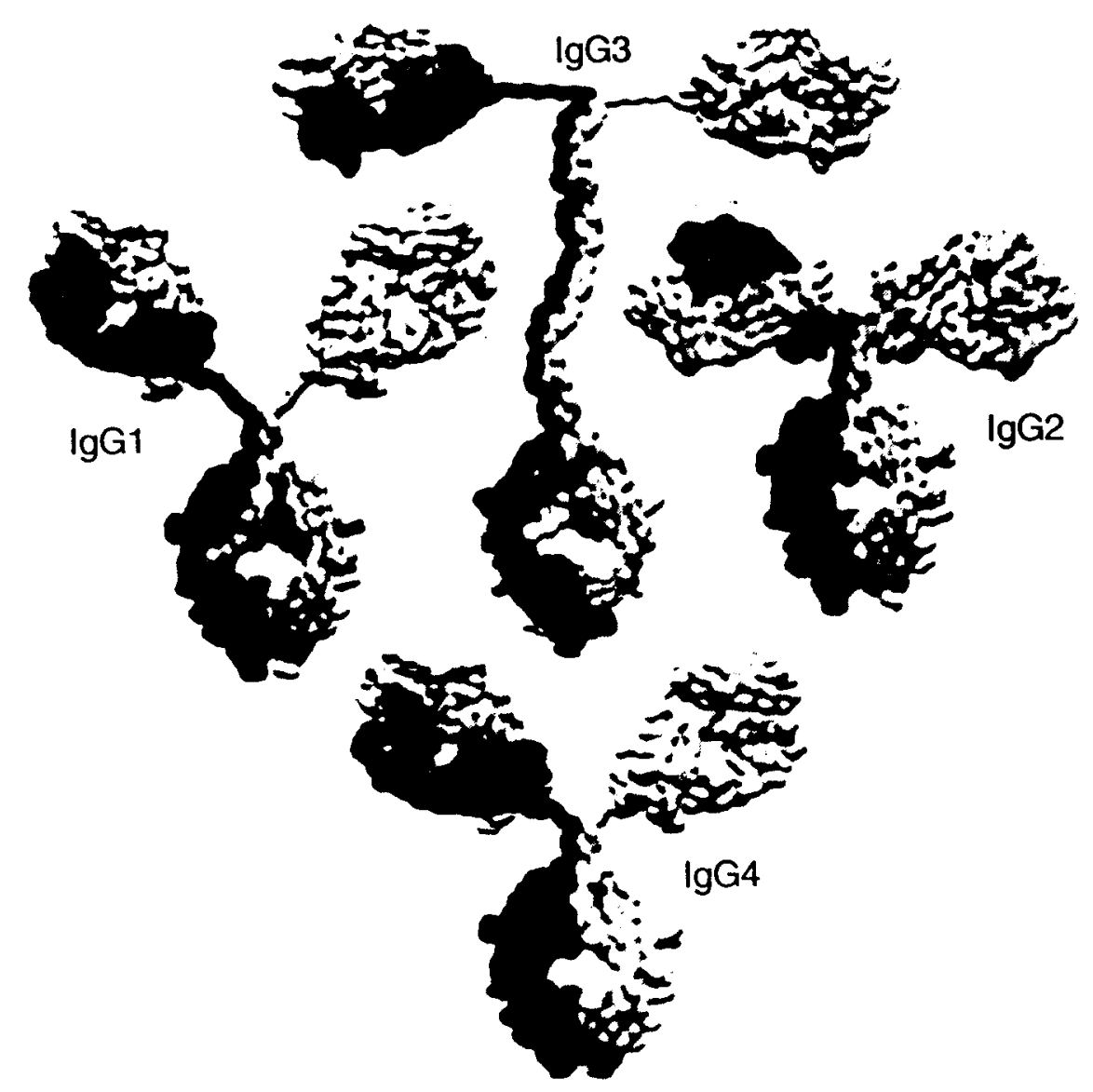

Figura 3 - Estruturas tridimensionais das subclasses da imunoglobulina $G$ (IgG). As formas das moléculas dos anticorpos são muito distintas, em grande parte, devido às diferenças de comprimentos nas regiões de dobradiças (apud: ABBAS, A.K., LICHTMAN, A.H., POBER, J.S. Imunologia celular e molecular. 3.ed. Rio de Janeiro: Revinter, 2000. p.49). 
Cada uma das subclasses da IgG possui propriedades e funções biológicas específicas, tais como a capacidade de fixar complemento, ligarse a macrófagos e atravessar a placenta (LEFRÈRE et al., 1993). Sabe-se que os anticorpos antivirais e as antinucleoproteínas são, principalmente, imunoglobulinas das subclasses IgG1 e IgG3, respectivamente. A deficiência da subclasse IgG1 é uma observação muito comum nas doenças imunológicas. A deficiência de IgG1 também ocorre em associação com a deficiência de outras subclasses da IgG, particularmente com a subclasse IgG3. A deficiência isolada de IgG2 é verificada em aproximadamente $10 \%$ das deficiências de IgG, particularmente em crianças (SHACKLEFORD e POLMAR, 1986; SODERSTROM et al., 1991). As respostas imunológicas contra polissacarídeos são encontradas na subclasse IgG2. A deficiência dessa subclasse está associada a infecções recorrentes, usualmente em doenças pulmonares (HAMMARSTROM et al., 1985; SCOTT et al., 1988).

Sabe-se que as moléculas da subclasse IgG3 têm maior atividade de fixação do complemento, seguida das subclasses: IgG1 e IgG2, respectivamente. A deficiência isolada de IgG3 é, possivelmente, a mais comum (cerca de 50 a 60\%) das deficiências das subclasses de IgG e pode ser encontrada tanto em adultos quanto em crianças com infecções respiratórias recorrentes (SODERSTROM et al., 1991). Outro tipo de deficiência da lgG3 está freqüentemente associada com a deficiência de IgG1, encontrada em cerca de 10 a 30\% dos casos e, com baixa freqüência (cerca de 4,5\%), está associada com a deficiência de IgG2 e IgA (OXELIUS et al., 1986; SKVARIL e SCHERZ, 1986).

Embora esteja presente em baixas concentrações no soro, a subclasse IgG4 tem recebido especial atenção dos pesquisadores por ser responsável pela ligação a diversos antígenos presentes no meio ambiente (WHO, 1982; IUIS/WHO, 1988). No organismo humano, a deficiência da IgG4 está freqüentemente associada às infecções recorrentes do trato respiratório (cerca de 25 vezes acima do normal) e à deficiência, particularmente, da subclasse IgG2, observada em cerca de $50 \%$ dos casos (HEINER et al., 1986; HEINER, 1988; MOSS et al., 1992). 


\subsection{Terapias de reposição com lgG}

As alterações imunológicas podem envolver qualquer componente do sistema imunológico e podem ser resultantes de predisposições genéticas, deficiências bioquímicas ou metabólicas, deficiências de vitaminas ou minerais e de outras deficiências adquiridas (BERKMAN, 1990; WORDELL, 1991). Na profilaxia e tratamento dos pacientes portadores de alterações de IgG ou de alguma de suas subclasses, o início ou mesmo a manutenção da reposição com imunoglobulina $\mathrm{G}$ depende de alguns importantes fatores. Os níveis séricos de outras classes de imunoglobulinas, tais como $\lg \mathrm{A}, \lg \mathrm{M}, \lg \mathrm{D}$ e IgE, além da avaliação dos níveis de linfócitos, neutrófilos e das funções complementares têm relevante importância nas decisões clínicas para reposição (BEARD e FERRANTE, 1988; ROBERTON et al., 1990).

SODERSTROM et al. (1991), além de BERNATOWSKAMATUSZKIEWICZ et al. (1991), argumentaram que a reposição com imunoglobulinas é realmente muito útil em crianças e adultos, nas deficiências das subclasses da lgG, associadas às deficiências de outras classes de imunoglobulinas. Na profilaxia e tratamento de pacientes com infecções bacterianas recorrentes e que apresentam deficiências de imunoglobulina $\mathrm{G}$ ou das subclasses, a administração desse anticorpo por via intravenosa tem-se mostrado uma terapia muito efetiva (COOPER e LAWTON, 1994).

Uma ampla variedade de doenças, tais como alérgicas, autoimunes, infecciosas, hematológicas, neurológicas e renais, estão associadas às deficiências das subclasses da IgG. As doenças alérgicas, tais como asma, estão associadas a níveis muitos baixos ou, de maneira oposta, a nível muito alto da subclasse IgG4 (HEINER et al., 1986). Tais doenças podem estar também relacionadas com níveis baixos das subclasses lgG2 e lgG3 (BJORKANDER et al., 1986) e nesses casos, PAGE et al. (1988) indicaram ser muito útil à administração, por via intravenosa, de imunoglobulina $G$.

A hepatite crônica ativa e outras doenças autoimunes estão associadas com as deficiências de IgG1 e lgG4 e o tratamento com 
imunoglobulinas tem sido largamente indicado (JEFFERIS e KUMARARATNE, 1990).

As deficiências de IgG e de suas subclasses podem estar presentes na diabetes mellitus dependente de insulina. Particularmente, verifica-se a deficiência da subclasse IgG1em cerca de $26 \%$ dos casos da doença, sendo administrado, com bons resultados, imunoglobulina da classe $G$ aos pacientes portadores dessas deficiências (CORTONA et al., 1992).

Segundo HAY et al. (1990), na Síndrome de Sjogren encontram-se deficientes as subclasses IgG1 e lgG4; porém, nessa doença observa-se também uma hipergamoglobulinemia na maioria dos pacientes.

Em 1988, TOKANO et al. demonstraram que os níveis das subclasses IgG3 e IgG4 estavam baixos no lupus eritematoso sistêmico.

Alguns pacientes com doenças pulmonares apresentam deficiências associadas das subclasses lgG2 e IgG4. BENTUR et al. (1991) demonstraram que também nesses casos a terapia com imunoglobulina $G$ mostrou-se muito benéfica. Em crianças, as infecções do trato respiratório causadas pelo vírus HIV do tipo 1 estão, na sua grande maioria, associadas a alterações nos níveis da subclasse IgG2 (BARTMANN et al., 1991; ROILIDES et al., 1991).

Em 1984, INSLER et al. relataram o caso de uma criança com blefaroquerato-conjuntivite, uma doença infecciosa bastante severa que está associada à deficiência da subclasse IgG4. Em 1986, HEINER et al. descreveram que o tratamento com imunoglobulina era muito eficiente nos casos de pacientes com deficiência da subclasse lgG4 associada a infecções, sendo até, uma terapia melhor do que a terapia realizada com antibióticos isoladamente e, inclusive, possibilitava a redução na freqüência das internações hospitalares. Em outros relatos clínicos, LOH et al. (1991) revelaram que a meningite estava associada com a deficiência de IgA e, particularmente, com a deficiência das subclasses lgG4 e lgG2. A pneumonia, causada pela Chlamydia trachomatis, foi notada em pacientes com deficiências de lgG1 e lgG4, porém, quando os mesmos foram tratados com imunoglobulina $\mathrm{G}$, houve total regressão da infecção (KLINGEBIEL et 
al., 1989).

Nas doenças neurológicas como a ataxia telangiectásica, os níveis da IgG2 e IgG4 e da IgA estão abaixo dos níveis normais (BERKEL, 1986; AUCOUTURIER et al., 1987). Em 1986, DUSE et al. revelaram que a epilepsia infantil estava associada à deficiência de $\lg G 2$ e $\lg G 4$. Os pesquisadores indicaram resultados satisfatórios quando as crianças portadoras dessa doença recebiam tratamento de reposição com imunoglobulina G. LOH et al. (1990), além de ANNEREN et al. (1992), observaram que a subclasse lgG4 e, em menor extensão a lgG2, encontrava-se em baixas concentrações em cerca de $50 \%$ dos pacientes portadores da Síndrome de Down e, essas deficiências estavam também associadas a infecções recorrentes.

Alguns fármacos, tais como a carbamazepina, causam acentuada redução no nível sérico da IgG2. Por outro lado, a fenantoína causa redução nos níveis de IgG3 e IgG4, associada ainda à redução de IgA (GILHUS e LEA, 1989), portanto, a terapia de reposição com imunoglobulinas está indicada.

Pacientes com infecções graves devido ao agente Haemophilus influenzae e em procedimentos de hemodiálise, apresentam baixas concentrações do anticorpo $\operatorname{lgG} 2$, sendo indicada a terapia de reposição com imunoglobulinas associada com antibióticos (BORRADORI et al., 1990).

\subsection{Tecnologias para obtenção e controle de qualidade de preparações de IgG}

A primeira preparação de imunoglobulina $G$ humana para uso humano foi obtida na década de 40 por COHN através do método de precipitação da proteína com etanol a baixas temperaturas (COHN et al., 1946; ONCLEY et al., 1949), mas o preparado ficou restrito à administração por via intramuscular (KLINE e SHEARER, 1996), devido às complicações alérgicas observadas nos pacientes que recebiam a medicação.

A partir da década de 60, com os avanços alcançados nas tecnologias de produção, surgiu a preparação de imunoglobulina $G$ de segunda geração 
obtida por um processamento industrial mais aprimorado fornecendo moléculas mais preservadas. A Cutter Biological (E.U.A.) foi a primeira indústria farmacêutica a preparar imunoglobulina $G$ intravenosa (Gamimune) com cerca de $80 \%$ a $90 \%$ de moléculas monoméricas.

Em 1982, um Comitê de Especialistas da Organização Mundial da Saúde (WHO) estabeleceu normas para produção e caracterização de IgG para uso humano por via intravenosa (iv), tais como moléculas mais puras e intactas; com baixa atividade anti-complementar; tolerância máxima de polímeros em até 5\%. Quatro anos mais tarde, foi produzida uma preparação de IgG (iv) (Gamimune-N) de pureza acima de 99\% e níveis superiores a 95\% de monômeros (produto de terceira geração) (McCUE et al., 1986).

Para que a terapia com imunoglobulinas seja clinicamente efetiva, os processos de fracionamento da matéria-prima (misturas de plasma humano) devem ser capazes de isolar e reter anticorpos puros e intactos, em outras palavras, as regiões ativas Fab e Fc devem estar totalmente preservadas. A manutenção da atividade biológica da imunoglobulina é de fundamental importância em funções imunes, tais como opsonização e eliminação bacteriana. Os processos de separação de IgG (iv) visam, principalmente, a obtenção de preparações com alto grau de pureza (conteúdo protéico superior a 90\% e inferior a 110\%) e concentração protéica média de 70g/L (30-180g/L) (Portaria MS n² 2.419 de 17/12/1996).

Os métodos usados no fracionamento de proteínas derivadas do plasma, entre outras, as imunoglobulinas, estão baseados principalmente no: 1) diferencial de solubilidade das proteínas, 2) diferencial de interação das proteínas com o meio sólido e 3) diferencial de interação das proteínas por ações físicas.

Os métodos, baseados no diferencial de solubilidade, mais empregados em escala industrial são: crioprecipitação, precipitação isoelétrica, precipitação de euglobulinas, dessalinização com sais neutros ou aminoácidos, precipitação com polímeros neutros (exclusão) (CURLING, 1983), fracionamento com etanol a frio (COHN et al., 1946), precipitação 
com clorofórmio (LIAUTAUD et al., 1974), precipitação com glicina (NEWMAN et al., 1971) e precipitação com polietilenoglicol (PEG) (WICKERHAUSER, 1971).

Os métodos, baseados no diferencial de interação com a fase sólida, usados em escala laboratorial, são: adsorção, cromatografia líquida de troca iônica (FRIESEN et al., 1983; SUOMELA et al., 1983), cromatografia de interação hidrofóbica, cromatografia de afinidade, cromatografia líquida de gel-permeação e separação em membrana (ultrafiltração) (CURLING, 1983) . Os avanços no desenvolvimento de novas tecnologias de produtos, tais como géis de sílica e géis sintéticos (tipo Mono Q, Mono P, Mono S Pharmacia Fine Chemicals), permitiram maior utilização em larga escala das técnicas de cromatografia no fracionamento de plasma.

Os métodos, baseados no diferencial de interação das proteínas por ações físicas, mais empregadas em escala laboratoriais são: centrifugação (separação sólido/líquido), técnicas de eletroforese e desnaturação por diferencial térmico; porém, esses métodos apresentam limitações técnicas para uso em escala industrial (SCHNEIDER et al., 1975).

Os processos de inativação viral, mais utilizados pelas indústrias de fracionamento, são: tratamentos químicos com solvente/ detergente ou com peróxido de hidrogênio, com pepsina em $\mathrm{pH}$ 4; técnicas de filtração; cromatografia de afinidade; tratamento físico com calor seco, tratamento físico com calor úmido (pasteurização), tratamento com vapor; além da exposição à radiação ultravioleta $(\lambda=254 \mathrm{~nm})$ associada com $\beta$-propiolactona (UEMURA et al., 1994).

As diferentes metodologias de separação e purificação, associadas com os processos de inativação viral existentes, possuem vantagens e desvantagens, por isso mesmo, não há ainda um consenso científico definitivo de quais metodologias seriam ideais.

O plasma pode ser obtido por duas diferentes vias: na primeira, o plasma pode ser separado do sangue total por processo de centrifugação; na segunda possibilidade, o plasma pode ser obtido diretamente por plasmaferese. Nos processos de separação e purificação da imunoglobulina 
da classe G, pode ser usado plasma fresco ou plasma congelado, isento de crioprecipitado e hemolisados. O tipo de anticoagulante utilizado na coleta do sangue total não interfere no fracionamento da IgG. Porém, se o processo de separação utilizado for por cromatografia em coluna, é essencial que o plasma apresente aspecto claro e isento de materiais em suspensão.

De acordo com as Diretrizes 91/507/EEC propostas pela Comunidade Européia, as preparações de IgG devem: estar livres de pirogênios causados por contaminações bacterianas; estar isentas de contaminantes microbianos que podem ser introduzidos por outros reagentes usados no processo de produção; estar isentas de contaminantes químicos que podem ser introduzidos por reagentes usados nos processos de produção, tais como enzimas, solventes, detergentes, anticorpos ou outros ligantes oriundos das etapas de purificação por cromatografia; manter sua atividade biológica; manter a distribuição das subclasses semelhante à distribuição normal no soro ou plasma humano.

A preparação de imunoglobulina da classe $G$, para uso humano por via intravenosa, pode estar sob a forma líquida ou liofilizada. A forma liofilizada deve ser reconstituída, no momento de uso, com um solvente apropriado recomendado pelo fabricante. 
3. MATERIAL E MÉTODOS 


\subsection{Material}

Todos os testes analíticos foram realizados em dez preparações de imunoglobulina da classe $\mathrm{G}$ ( $\mathrm{IgG}$ ), para uso humano por via intravenosa (iv), de diferentes marcas e procedências: Europa, Ásia, América do Norte, África e América do Sul. ${ }^{1}$

As preparações de IgG foram numeradas de 1 a 10 e as informações sobre os números de lotes e procedências dos produtos encontram-se descritas na Tabela 2.

Tabela 2- Preparações de imunoglobulina da classe G (IgG) para uso humano por via intravenosa obtidas de misturas de plasma de variadas procedências e processadas por diferentes técnicas de separação.

\begin{tabular}{c|c|c}
\hline PREPARAÇÕES & PROCEDÊNCIAS & LOTES \\
\hline 1 & Marburg (Lahn), Alemanha & 66021 \\
\hline 2 & Kankakee(Illinois), Estados Unidos & R-501111 \\
\hline 3 & Viena, Áustria & 7070028481 \\
\hline 4 & Berna, Suíça & 32826 \\
\hline 5 & Viena, Áustria & 24564961 \\
\hline 6 & Goldbrink, Alemanha & 84883 \\
\hline 7 & Pinetown, África do Sul & GIVH- 45 \\
\hline 8 & Bombaim, Índia & GLV 0196 \\
\hline 9 & Elkhart, Estados Unidos & 640 R068 \\
\hline 10 & São Paulo, Brasil & $4849-1$ \\
\hline
\end{tabular}

\footnotetext{
${ }^{1}$ Um frasco, de um único lote de cada uma das preparações, foi utilizado para os testes laboratoriais. Cada lote representa misturas de plasma de 1.000 a 10.000 doadores.
} 
As especificações das preparações de IgG, declaradas por cada fabricante, constam no Anexo A.

Conforme recomendações feitas nas monografias internacionais para separação e purificação de imunoglobulina da classe $G$ para uso humano (iv), as preparações comercializadas devem conter todas as subclasses da IgG: IgG1, IgG2, IgG3 e IgG4, numa proporção similar àquela encontrada no plasma humano normal (WHO, 1982; OMS Comitê de Especialistas, 1994; European Pharmacopoeia, 1997). Para determinarmos a distribuição das subclasses da IgG, misturas de plasma humano normal de, no mínimo, 1000 doadores foram usadas como referência (Anexo A).

\subsection{Métodos de análises}

\subsubsection{Determinação das subclasses IgG1, IgG2, IgG3 e IgG4}

Para determinação da distribuição das subclasses IgG1, IgG2, IgG3 e IgG4, nas preparações de imunoglobulina $G$ (iv), utilizamos ensaios imunoenzimáticos (ELISA) "Bindazyme ${ }^{\mathrm{TM}}$ Human Immunoglobulin G (IgG) Subclass - Kit"; The Binding Site, Birminghan, Inglaterra. Os ensaios foram feitos em triplicatas, seguindo todas as instruções recomendadas pelo fabricante, que validou o método de análise de acordo com os padrões de referência CRM470 (CARR-SMITH et al., 1997). Misturas de plasma humano de, no mínimo, 1000 doadores, apresentando os seguintes valores de referência na distribuição das subclasses: IgG1 (60-70\%); IgG2 (14-20\%); IgG3 (4-8\%); IgG4 (2-6\%) (BASSION, 1989; JEFFERIS e KUMARATNE, 1990), foram usadas para comparação com resultados das subclasses obtidos nas preparações de IgG. As leituras de absorbância dos padrões, dos calibradores e das amostras foram feitas, dentro do limite de trinta minutos após o bloqueio das reações, em um sistema de leitora de microplacas Bio-Tek Instrument, modelo Elx 800, com filtro de comprimento de onda $(\lambda) 450 \mathrm{~nm}$. Conforme declarado pelo fabricante do kit, os limites mínimos de sensibilidade do método analítico são: $\operatorname{lgG} 1=0,42 \mu \mathrm{g} / \mathrm{L} ; \operatorname{lgG} 2=$ $7,35 \mu \mathrm{g} / \mathrm{L} ; \operatorname{lgG} 3=0,29 \mu \mathrm{g} / \mathrm{L} ; \operatorname{lgG} 4=0,44 \mu \mathrm{g} / \mathrm{L}$. 


\subsubsection{Testes laboratoriais de sorologia e biologia molecular}

Para investigarmos a segurança das preparações de imunoglobulina G (iv) quanto à eficácia dos processos para inativação de microorganismos patogênicos transmissíveis pelo sangue, tais como vírus da hepatite $B$ (HBV), da C (HCV), da A (HAV), da imunodeficiência humana (HIV), da leucemia/linfoma de linfócitos $T$ do adulto e a paraparesia espástica tropical (HTLV I/II) e do Parvovírus B19, foram realizados testes de triagem sorológica por ensaios imunoenzimáticos (ELISA), Western Blot, nefelometria, imunofluorescência indireta (IFI), VDRL e determinação do material genético (DNA ou RNA) através da reação em cadeia da polimerase (PCR), seguindo-se todas as recomendações feitas pelos fabricantes dos conjuntos diagnósticos.

\subsubsection{Leucemia/linfoma de linfócitos $T$ do adulto e a paraparesia espástica tropical ou mielopatia (HTLV I/II)}

O teste para a detecção dos anticorpos IgG contra o vírus HTLV I/II foi realizado por ELISA utilizando-se duas marcas diferentes de conjuntos diagnósticos: 1) "Vironostika HTLV I/II - Microelisa System", Organon Teknica, Boxtel, Holanda; 2) "Murex* HTLV I + II", Murex, Dartford, Inglaterra (UK). As medidas de absorbância dos padrões, dos calibradores e das amostras foram feitas em um sistema automatizado de leitora de microplacas Microwell System, modelo 3000, Organon, com filtro de comprimento de onda $(\lambda) 450 \mathrm{~nm}$, dentro do limite de trinta minutos após bloqueio das reações.

Para o teste de Western Blot utilizou-se conjunto diagnóstico "HTLV BLOT 2.4", Genelabs Diagnostics (GLD), Singapura, teste imunoenzimático qualitativo "in vitro". De acordo com o fabricante do conjunto diagnóstico utilizado, a presença das frações antigênicas, que indicam soropositividade para HTLV I são (gag) p19 com ou sem p24 e as bandas (env) GD21 e rgp46-I; reagente para HTLV II são (gag ) p24 com ou sem p19 e as bandas (env) GD21 e rgp46-II. 


\subsubsection{Hepatite C (HCV)}

O teste para detecção dos anticorpos IgG contra o vírus da hepatite $C$ $(\mathrm{HCV})$ foi realizado por: ELISA, Western-Blot e PCR. No teste por ELISA utilizaram-se os conjuntos diagnósticos: 1) "HBK 425- Hemobio - HCV", Embrabio, São Paulo, Brasil; 2) "Murex Anti-HCV (Version III)", Murex. No teste por Imuno-dot utilizou-se conjunto diagnóstico "LiaTek ${ }^{\circledR} \mathrm{HCV}$ III", Organon. Para detecção do material genético (RNA) do vírus por PCR foram utilizados os conjuntos diagnósticos: 1) "Amplicor ${ }^{\circledR}$ HCV - HCV Detection ", Roche, New Jersey, U.S.A.

\subsubsection{Hepatite B (HBV)}

Os marcadores imunológicos do vírus $\mathrm{B}$ da hepatite: o antígeno de superfície (AgHBs), os anticorpos IgG contra o antígeno de superfície (antiHBs) e contra o antígeno do centro (core) (anti-HBc) foram detectados por ELISA. Para o teste de detecção do antígeno de superfície da hepatite B (AgHBs) utilizou-se o conjunto diagnóstico "Hepanostika ${ }^{\circledR} \mathrm{HBsAg}$ Uni-Form II", Organon. Para o teste de detecção dos anticorpos IgG contra o HBs foi utilizado conjunto diagnóstico "Murex anti-HBs", Murex. Para detecção de anticorpos IgG contra o antígeno do core (anti-HBc), utilizou-se conjunto diagnóstico "Hepanostika ${ }^{\circledR}$ anti-HBc", Organon.

\subsubsection{Hepatite A (HAV)}

O teste para detecção dos anticorpos IgG e IgM contra o vírus da hepatite $A$ foi realizado por ELISA com conjuntos diagnósticos: 1) "Hepanostika ${ }^{\circledR}$ HAV Antibody (IgG)", Organon; 2) "Hepanostika ${ }^{\circledR}$ HAV IgM", Organon.

\subsubsection{Síndrome da Imunodeficiência adquirida (AIDS) (HIV 1/2)}

O teste para a detecção dos anticorpos IgG contra os vírus da imunodeficiência adquirida, tipos $1 / 2$ (HIV 1/2), foi realizado por ELISA com duas marcas diferentes de conjuntos diagnósticos: 1) "ICE* HIV-1.0.2, marca Murex; 2) "Vironostika ${ }^{\circledR}$ ", Organon. 


\subsubsection{Sífilis}

O teste para a detecção de anticorpos lgG contra o espiroqueta Treponema pallidum (T. pallidum) foi realizado pelas técnicas: ELISA e imunofluorescência indireta (FTA-ABS). As reaginas ou anticorpos não treponêmicos foram determinadas por reação de VDRL. Nos testes por ELISA, utilizaram-se dois conjuntos diagnósticos diferentes: 1)"Trepanostika ${ }^{\circledR}$ ", Organon; 2) "ICE* Sífilis + ICE* Base", Murex. No teste por VDRL, utilizou-se conjunto diagnóstico: "Antígeno RPR- BRÁS", Laborclin, Pinhais, Brasil. O teste realizado por imunofluorescência indireta (FTA-ABS) utilizou conjunto diagnósticos: 1) Conjugados fluorescentes líquidos "Fluolines H"; 2) "Sorbent (extrato liofilizado de Treponema de Reiter); 3) "Imuno ${ }^{\text {pallidum }}$, Biolab, Jacarepaguá, Brasil.

\subsubsection{Parvoviroses (Parvovírus B19)}

O material genético (DNA) do parvovírus B19 foi determinado através da reação em cadeia da polimerase (PCR), de acordo com os procedimentos descritos por DURIGON et al. (1993) e LISBOA (1997). Na primeira etapa do método, foi feita a amplificação de um fragmento de 284 pares de bases referente a uma região não estrutural do genoma do B19, empregando-se "primers" P1 e P6.

Em seguida, foi feita uma segunda amplificação de uma região interna do produto já amplificado (106 pares de bases), utilizando-se os "primers" P2 e P5. Os "primers" foram preparados segundo o método descrito por SINHA et al. (1984). Foram utilizados os seguintes reagentes: tampão Tris 10mM (pH 8,3); $\mathrm{MgCl}_{2} 2 \mathrm{mM}$; gelatina 0,01\%; $\mathrm{KCl} 50 \mathrm{mM}$; deoxinucelotídeo trifosfato

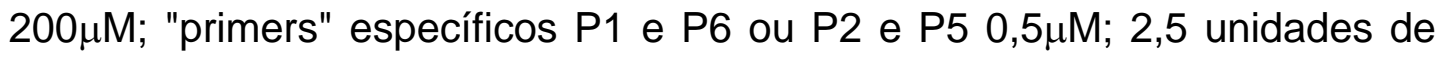
Taq-DNA polimerase (Perkin-Elmer Cetus, Norwalk) e $10 \mu \mathrm{L}$ de cada produto de extração, perfazendo um volume final de $100 \mu \mathrm{L}$. Para controle da reação, utilizou-se o plasmídio pYT103, que contém um clone padrão do fragmento do DNA do parvovírus B19 (COTMORE, 1984). A amplificação foi feita em termociclador automático (Perkin-Elmer Cetus), através da realização de 35 ciclos em três temperaturas diferentes: 1) $95^{\circ} \mathrm{C}$ por 60 segundos na fase de 
desnaturação das fitas de DNA; 2) $55^{\circ} \mathrm{C}$ por 45 segundos para anelamento dos "primers" e 3) $72^{\circ} \mathrm{C}$ por 90 segundos para extensão das fitas.

A detecção dos produtos amplificados foi observada por eletroforese em gel de agarose $2 \%$, sob voltagem de 100 volts. A coloração dos produtos amplificados foi feita utilizando-se brometo de etídio $0,5 \mu \mathrm{g} / \mathrm{mL}$ e a visualização foi feita em sistema de luz ultravioleta (UV).

\subsubsection{Testes de atividade de anticorpos específicos para investigação da eficácia das preparações de IgG}

\subsubsection{Anticorpos anti-estreptolisina O (ASLO)}

O teste para detecção dos anticorpos IgG anti-estreptolisina O (ASLO) foi realizado por nefelometria com reagentes "Immunochemistry Systems Antistreptolysin O - ASO ${ }_{M P E} "$, Beckman, Califórnia, U.S.A. Para leitura das medidas de dispersão da luz, foi utilizado um equipamento denominado nefelômetro Array Protein System Software 2.1, Beckman. Segundo os fabricantes do equipamento, o teste apresenta sensibilidade de $100 \%$ e especificidade de $93 \%$.

\subsubsection{Anticorpos antivírus da rubéola}

O teste para detecção de anticorpos IgG contra o vírus da rubéola foi realizado por ELISA através do conjunto diagnóstico: "Cobas ${ }^{\circledR}$ Core Rubella IgG recomb", Roche, São Paulo, Brasil.

\subsubsection{Anticorpos anti-Toxoplasma gondii}

O teste para detecção dos anticorpos IgG contra o parasita Toxoplasma gondii foi realizado por ELISA através do conjunto diagnóstico: "Cobas. Core Toxo IgG" ", Roche.

\subsubsection{Anticorpos anti-Chlamydia trachomatis}

O teste para detecção de anticorpos IgG contra a bactéria Chlamydia trachomatis foi realizado por imunofluorescência indireta através do conjunto 
diagnóstico: "Chlamydia trachomatis IgG" ", Hemagen.

\subsubsection{Anticorpos anti-citomegalovírus}

O teste para detecção de anticorpos IgG contra o citomegalovírus foi realizado por ELISA através do conjunto diagnóstico: "Cobas ${ }^{\circledR}$ Core $\mathrm{CMV}$ IgG", Roche.

\subsubsection{Anticorpos antivírus herpes simples (1/2)}

O teste para detecção de anticorpos IgG contra os vírus herpes simples (1/2) foi realizado por imunofluorescência indireta através do conjunto diagnóstico: "Herpes simples tipos 1 e 2 (HSV-1/2) lgG", Hemagen.

\subsubsection{Princípio dos testes}

\subsubsection{Ensaio imunoenzimático (ELISA)}

O emprego de conjugados enzimáticos em imunoensaios foi relatado por ENGVALL e PERLMANN (1972). Os ensaios imunoenzimáticos são baseados na utilização de antígenos ou anticorpos marcados com enzimas e permitem a detecção, titulação e quantificação de substâncias de interesse biológico. Vários métodos foram desenvolvidos para a localização de constituintes celulares; para a medida de pequenas quantidades de antígenos, haptenos e anticorpos e para a detecção de imunoprecipitados.

Nas técnicas imunoenzimáticas, um dos fatores mais importantes é a eficiência do conjugado empregado, que se refletirá na escolha de três componentes: o anticorpo ou o antígeno, a enzima e o processo de conjugação, cujas características, por sua vez, variam de acordo com a técnica empregada. A fase sólida, usada para imobilização de um dos reagentes, pode ser constituída por partículas de agarose, poliacrilamida, dextran, poliestireno, entre outras (SANCHEZ, 1996).

Os conjugados devem ser preparados com anticorpos de alta afinidade e maximamente purificados. Os substratos cromogênicos empregados na degradação enzimática dão origem a produtos solúveis coloridos, cuja determinação é feita medindo-se a densidade óptica da solução em espectrofotômetro. As reações imunoenzimáticas são 
bloqueadas com a adição de ácido sulfúrico (solução de parada). Nas reações com a enzima peroxidase, o substrato utilizado é o peróxido de hidrogênio $\left(\mathrm{H}_{2} \mathrm{O}_{2}\right)$ e os cromógenos ou doadores de hidrogênio mais empregados são a ortofenilenodiamina (OPD), o ácido 5-aminosalicílico, a ortotoluidina, o 2,2'-diazino do ácido etilbenzotiazolino sulfônico (ABTS) e a tetrametilbenzidina (TMB).

Os métodos mais empregados por ELISA são: o método indireto para pesquisa de anticorpos; o método de captura para anticorpos IgM; o método de captura para antígenos; o método de competição com antígeno marcado; o método de competição com anticorpo marcado.

No método indireto para a pesquisa de anticorpos, os orifícios das placas plásticas são sensibilizados com o antígeno que, após a reação de bloqueio, reage com os anticorpos da amostra. $O$ conjugado antiimunoglobulina humana reage com o anticorpo capturado pelo antígeno e a reação é revelada com a solução cromogênica. A reação é bloqueada e a intensidade de cor é estimada fotometricamente. O grau de degradação do substrato, indicado pela intensidade de cor da solução, é proporcional à concentração de anticorpo presente (SANCHEZ, 1996).

No método de captura (indireto) para detecção de anticorpos IgM, a fase sólida é sensibilizada com anti-IgM específico para a região Fc.da imunoglobulina. A amostra é incubada e se houver anticorpos IgM, os mesmos serão capturados. A seguir, incuba-se a amostra com antígeno marcado ou antígeno não-marcado, seguido de anticorpo específico marcado. A técnica não exige antígeno purificado. A reação é revelada pela adição de solução cromogênica e substrato (SANCHEZ, 1996; SÁEZALQUÉZAR et al., 1996).

O método de captura, com excesso de anticorpo marcado, é o mais utilizado para antígenos polivalentes. A fase sólida é sensibilizada com anticorpo específico. A amostra em teste é incubada com a fase sólida e em seguida incubada com excesso de anticorpo marcado e enzima. A reação é revelada pela adição de solução cromogênica e substrato. A taxa de degradação é proporcional à concentração do antígeno (SANCHEZ, 1996). 
No método de competição com antígeno marcado, as placas são sensibilizadas com anticorpo específico, incubadas com o conjugado antígeno-enzima, na presença da amostra em que se quer pesquisar o antígeno, ou de um padrão de antígeno. Após a obtenção do equilíbrio da reação antígeno-anticorpo, incuba-se o preparado com uma solução do substrato da enzima. A reação enzimática é interrompida pela adição de solução bloqueadora e as leituras são feitas por espectrofotometria. Há uma relação inversamente proporcional entre a concentração de antígeno na amostra ou no padrão e as densidades ópticas.

No método de competição com anticorpo marcado, o antígeno é ligado à placa e a ligação do anticorpo marcado é inibida por competição pela adição de antígeno padrão ou da amostra. As demais etapas são semelhantes às do método com antígeno marcado. As densidades ópticas obtidas são inversamente proporcionais à concentração do antígeno na amostra ou no padrão (SANCHEZ, 1996). O ensaio de competição com anticorpo marcado é indicado na detecção do anti-HBc-lgG, no qual a fase sólida é recoberta com 0 antígeno de core da hepatite $\mathrm{B}$ (AgHBc). Juntamente com as amostras, coloca-se uma quantidade padronizada de antiHBc-IgG*. As amostras que não contêm antiHBc-lgG, todo anti-HBc IgG* liga-se ao antígeno da fase sólida. Após a revelação, o aparecimento de coloração intensa indica um resultado negativo (SÁEZ-ALQUÉZAR et al., 1996).

\subsubsection{Técnica de biologia molecular - PCR}

A amplificação pela reação em cadeia da polimerase (PCR), feita em ciclos repetitivos de aquecimento e resfriamento (30 a 40 ciclos), é baseada na multiplicação exponencial, "in vitro", de um fragmento de DNA alvo por uma enzima DNA polimerase termoestável, chamada Taq polimerase. Esta enzima, resistente ao calor, é extraída do bacilo Thermus aquaticus (MULLIS e FALOONA, 1987; MOLLISON et al., 1997) e sua descoberta permitiu a automação do processo. O caráter exponencial da amplificação por PCR se deve ao fato de que o DNA sintetizado em um ciclo serve como molde para 
o próximo. Na prática, pode ocorrer uma redução na eficiência de amplificação devido à inativação da enzima e à presença de quantidades limitadas de componentes no final do processo de amplificação (SANCHEZ, 1996).

Os "primers", usados na hibridização dos fragmentos específicos do gene, são moléculas de DNA de fita simples com 30 a 40 polinucleotídeos que servem como modelos para a polimerização do novo DNA. Tanto o DNA como o RNA pode ser utilizado como moldes na amplificação.

De modo geral, na primeira etapa da reação, as duplas fitas do DNA alvo são desnaturadas sob temperaturas que variam de 94 a $96^{\circ} \mathrm{C}$. Na etapa seguinte, sob temperatura de $55^{\circ} \mathrm{C}$, ocorre o anelamento dos "primers" que flanqueiam a região da fita simples de DNA alvo a ser amplificada. Na última etapa de reação, a extensão das fitas é feita pela ação enzimática da Taq polimerase na presença dos deoxiribonucleotídeos trifosfatos (dNTPs) e íons magnésio $\left(\mathrm{Mg}^{2+}\right)$ a $72^{\circ} \mathrm{C}$ (MULLIS e FALOONA, 1987). Os produtos da PCR podem ser analisados por hibridização reversa "dot blot" ou por eletroforese em gel de agarose seguida pela coloração com brometo de etídio e visualização em sistema de luz ultravioleta. O teste de "dot blot", desenvolvido por HAWKES et al., em 1982, utiliza membrana de nitrocelulose, na qual pequenas quantidades de amostra são aplicadas na forma de gotas.

O método de PCR permite a obtenção de grande quantidade de DNA específico a partir de preparações de DNA complexo. A amplificação de seqüências específicas de DNA não só permite um aumento muito grande no número de cópias a serem detectadas. A produção em quantidade suficiente da seqüência específica de DNA aumenta a sensibilidade de detecção e torna mais fácil a identificação de bactérias, fungos, vírus e protozoários.

Trata-se de um método muito sensível, mas a sensibilidade depende de uma adequada preparação da amostra. O risco de contaminação com DNA estranho (não alvo) pode ser controlado separando-se as áreas de preparação das amostras das áreas de análise do produto. 


\subsubsection{Imunofluorescência Indireta (IFI)}

Em 1954, o teste com anticorpos fluorescentes (método indireto de impregnação) foi descrito por WELLER e COONS. O método é considerado muito sensível, específico, reprodutível, de fácil padronização e execução.

$O$ teste de imunofluorescência baseia-se na capacidade das moléculas de anticorpo se ligarem covalentemente a fluorocromos sem perder sua reatividade específica com o antígeno. Fluorocromos são substâncias que absorvem luz de um comprimento de onda menor e, quando excitados com luz ultravioleta, emitem luz de comprimento de onda maior, fenômeno físico denominado fluorescência. Os fluorocromos mais utilizados são o isotiocianato de fluoresceína e a tetrametil-rodamina $B$, que possuem espectros de emissão e de absorção diferentes, porém absorvem e emitem luz na faixa do visível.

A intensidade de luz emitida pelo isotiocianato de fluoresceína depende do $\mathrm{pH}$ do meio, sendo máxima em pH 8,5. Por isso, as preparações são montadas com glicerina alcalina. $\mathrm{O}$ uso de corantes, como o azul de Evans, diminui a coloração de fundo. O microscópio de fluorescência é composto por uma fonte de luz de alta intensidade (lâmpada de mercúrio ou de quartzo-halogênio), filtros de excitação, que relacionam comprimento de onda capaz de ativar a fluorescência e filtros que atuam como barreiras, removendo interferentes da luz e permitindo alta transmissão da fluorescência emitida.

Quando se deseja detectar anticorpos específicos de uma determinada classe ou subclasse de imunoglobulinas, é necessário o emprego de anti-soros específicos para as cadeias pesadas das classes que se quer pesquisar e sem reatividade para as cadeias leves ou para outras cadeias pesadas. Assim, por exemplo, conjugados anti-IgG cujos anti-soros possuem reatividade contra as cadeias leves, $\kappa$ e $\lambda$, detectam anticorpos contra todas as classes de imunoglobulinas reagentes (SANCHEZ, 1996).

Na pesquisa de anticorpos, os procedimentos são realizados em duas etapas de reações. Na primeira etapa, as amostras são incubadas com o 
substrato antigênico específico para permitir a formação do complexo antígeno-anticorpo. Após lavagens, na segunda etapa da reação, os imunocomplexos formados são incubados com um conjugado contendo antiIgG humano de cabra marcada com fluoresceína. Nas reações positivas, ocorre a formação de um complexo antígeno-anticorpo específico de cor verde-maçã fluorescente intensamente brilhante, que pode ser visualizado em microscópio de fluorescência utilizando-se comprimentos de onda de excitação máxima em 490nm e de emissão média em 520nm. A maior intensidade de fluorescência que se observa nas técnicas indiretas se deve ao maior número de moléculas fluorescentes que irão corresponder a cada determinante antigênico (SANCHEZ, 1996).

\subsubsection{Nefelometria}

O princípio do método consiste em recobrir partículas de poliestireno com uma hemolisina, a estreptolisina O (SLO) recombinante, altamente purificada. Quando as partículas recobertas com SLO entram em contato com a amostra contendo anticorpos anti-SLO, são formados imunocomplexos que aumentam a dispersão de um feixe de luz. Este aumento na dispersão de luz é convertido num pico proporcional à concentração de anti-estreptolisina O (ASLO) presente na amostra. Após feitas as calibrações necessárias, um equipamento denominado nefelômetro, converte automaticamente o sinal cinético máximo em unidades de concentração (MARRRACK e RICHARDS, 1971; STEMBERG, 1977; ELEFANT, 1996).

\subsubsection{Western Blot}

Um dos métodos mais utilizados para identificar proteínas específicas reconhecidas por anticorpos tem sido o "immunoblotting" ou Western Blot, para diferenciar do Southern e Northern Blot, que se referem à identificação de ácidos nucléicos.

Trata-se de um método no qual as proteínas são separadas, de acordo com seu peso molecular, por eletroforese em gel de poliacrilamida contendo 
um detergente aniônico chamado dodecilsulfato de sódio (SDS-PAGE), que se liga às regiões hidrofóbicas das proteínas em quantidade proporcional ao seu peso molecular, conferindo-lhes carga negativa, de modo que elas migram para o polo positivo. Após a separação, as proteínas são transferidas eletroforeticamente para uma membrana (tira) de nitrocelulose, onde ficam imobilizadas, conforme descrito por TOWBIN et al. (1976).

Depois de realizada a transferência, a membrana é processada por ensaio imunoenzimático semelhante ao método da imunoperoxidase. Antes da reação, é importante que as membranas sejam incubadas com uma solução de proteína inerte (leite desnatado, solução de albumina bovina ou gelatina) para evitar a adsorção inespecífica.

Após reação de bloqueio, as membranas são incubadas com a amostra em que se quer pesquisar os anticorpos, ou com anticorpos monoclonais ou policlonais específicos para os antígenos em estudo. Em seguida, são feitas sucessivas lavagens das tiras com solução tampão como Tris-Tween 20.

Posteriormente, as tiras são incubadas com o conjugado enzima e antiimunoglobulina específica (anti-lgG humano de cabra marcado). Após novas etapas de lavagem, adiciona-se o substrato cromogênico específico para a enzima utilizada no teste. As enzimas mais utilizadas são a peroxidase, a fosfatase alcalina e a glicose-oxidase. Para a enzima peroxidase, os substratos mais empregados são a diaminobenzidina e o 4cloro-1-naftol que, sob a ação da enzima, originam os imunoprecipitados. Para a fosfatase alcalina, os substratos mais usados são o substrato 5bromo-4-cloro-3-indolilfosfato (BCIP) e o nitrobluetetrazolium (NBT) (SANCHEZ, 1996). Procede-se às leituras das bandas formadas nas tiras, comparando-as com os controles. 


\subsubsection{Teste de aglutinação de cristais de colesterol}

Em 1946, o teste de VDRL (Venereal Disease Research Laboratory), desenvolvido por HARRIS et al., emprega suspensões de cristais de colesterol como suporte da cardiolipina em meio aquoso contendo lecitina para a pesquisa de anticorpos antilipídicos na sífilis.

O teste detecta anticorpos antilipídicos que se formam no hospedeiro como resposta ao material de natureza lipídica liberado pelas células lesadas no início da infeção e ao material lipídico do próprio treponema. A leitura do teste pode ser feita macroscopicamente, contra um fundo escuro, após alguns minutos de agitação, ou por microscopia óptica. O teste positivo apresenta a formação de flóculos, enquanto o negativo apresenta aspecto homogêneo e sem agregados (SANCHEZ, 1996).

\subsubsection{Procedimentos industriais de separação e purificação de IgG} obtida de plasma humano por cromatografia em coluna realizados na Fundação Pró-Sangue Hemocentro de São Paulo

Em 1993, pela primeira vez na América Latina, TANAKA et al. iniciaram, na Fundação Pró-Sangue Hemocentro de São Paulo, o processamento industrial para obtenção de preparações de IgG, uso em humanos por via intravenosa, seguindo a metodologia de separação e purificação por cromatografia em coluna descrita por CURLING (1983). Posteriormente, TANAKA et al. (1998) implementaram modificações no processamento industrial. Todas as especificações de produção e controle de qualidade estão concordantes com as recomendadas pela Farmacopéia Européia e Americana, pela Comunidade Européia para Produção de Hemoderivados e pela Portaria MS n 2.419 de 17/12/1996 do Ministério da Saúde do Brasil. 


\subsubsection{Tratamento da matéria-prima}

A planta experimental, com capacidade de produção mensal em torno de 200 frascos (capacidade $50 \mathrm{~mL}$ cada) de IgG, utiliza $100 \mathrm{~L}$ de plasma humano congelado $\left(-20^{\circ} \mathrm{C}\right)$. Todo plasma usado é submetido a rigorosos testes sorológicos e somente é utilizada a matéria-prima com resultados negativos para as determinações da Doença de Chagas, Sífilis, anti-HIV, anti-HTLV I/II, anti-HCV, anti-HBc e AgHBs.

Todas as bolsas de plasma, que apresentam irregularidades, tais como bolsas com rupturas, conteúdo lipêmico ou conteúdo hemolisado, são desprezadas.

O processo de fracionamento do plasma inicia-se pela lavagem, com água destilada e etanol $70 \% \mathrm{v} / \mathrm{v}$, das bolsas plásticas contendo o plasma congelado. Todo plasma recolhido é deixado em repouso na câmara fria ( $2 \mathrm{a}$ $4{ }^{\circ} \mathrm{C}$ ) por uma noite para completo degelo. A seguir, o plasma totalmente degelado é submetido à clarificação em duas etapas: por centrifugação de vazão contínua a $5.000 \mathrm{~g}$ e posterior filtração em filtro de profundidade especificação 30-S (Zeta Plus, Cuno) para retirada de materiais insolúveis, tais como fibrinas.

\subsubsection{Desalinização do plasma}

O plasma clarificado é aplicado na coluna cromatográfica, modelo BPSS $400 / 600$, de diâmetro $40 \mathrm{~cm}$ e comprimento $60 \mathrm{~cm}$, contendo resina Sephadex G-25 (ligações cruzadas de dextran) (Figura 4). 


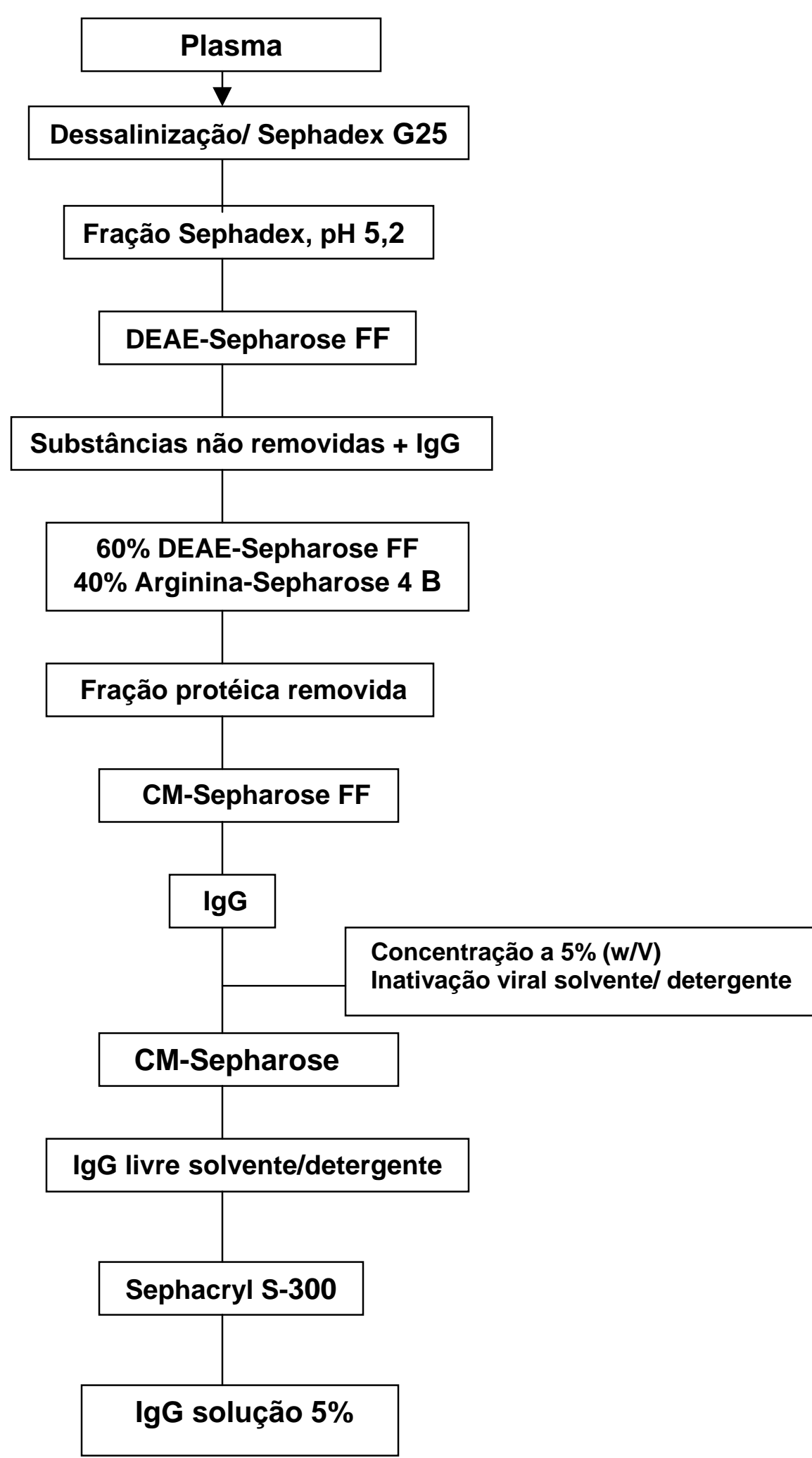

Figura 4 - Diagrama do processo de separação e purificação de plasma para obtenção de imunoglobulina da classe $\mathrm{G}$ por cromatografia em coluna. 
Essa resina tem como principal função, retirar sais inorgânicos do plasma em processamento. É largamente usada no processo de fracionamento industrial, pois possui alta eficiência na separação das frações de interesse, em ordem decrescente de peso molecular. Utiliza-se solução de acetato de sódio $5 \mathrm{mM}$ e condutividade $0,37 \mathrm{mS} / \mathrm{cm}$ para eluir o plasma da coluna.

\subsubsection{Precipitação das euglobulinas}

As euglobulinas são separadas por precipitação acertando o $\mathrm{pH}$ do meio para 5,2 pela adição de ácido acético $1 \mathrm{M}$. O plasma é deixado novamente em repouso a $4{ }^{\circ} \mathrm{C}$, por mais uma noite para total precipitação das euglobulinas.

O precipitado formado é removido por centrifugação e em seguida descartado. A parte solúvel ou sobrenadante é clarificada por filtração.

\subsubsection{Separação de IgG}

$\mathrm{O}$ pH do plasma clarificado é novamente ajustado para 5,2 com ácido acético $1 \mathrm{M}$ e, a condutividade da solução ajustada para 1,4mS/cm com cloreto de sódio 0,15M. Em ciclos automatizados, o plasma é aplicado numa outra coluna cromatográfica, modelo PS-370/15, contendo resina de troca aniônica DEAE-Sepharose FF (ligações cruzadas de agarose), previamente equilibrada com tampão acetato de sódio $20 \mathrm{mM}, \mathrm{pH} \mathrm{5,2} \mathrm{e} \mathrm{condutividade}$ 1,4mS. O princípio básico da cromatografia de troca iônica está fundamentado na separação das moléculas de acordo com as cargas elétricas das mesmas. Particularmente, a resina usada nessa etapa possui alta eficiência de separação mesmo quando a diferença de cargas das moléculas presentes é muito pequena, como por exemplo, na presença de moléculas de proteínas que diferem entre si por um único aminoácido. Após três ciclos de eluição do plasma com tampão acetato em diferentes concentrações, obtém-se a separação entre imunoglobulina e albumina. A seguir, após o ajuste do pH da solução para 6,0 com hidróxido de sódio 1M e ajuste da condutividade para $1,4 \mathrm{mS} / \mathrm{cm}$, a fração contendo as imunoglobulinas é aplicada em duas outras colunas cromatográficas 
acopladas em série. A primeira coluna, modelo PS-370/15, contém uma mistura de 40\% de arginina- Sepharose 4B / 60\% de DEAE-Sepharose FF. A segunda coluna, modelo Index 200/500, contém 8 litros de CM-Sepharose FF. As proteínas que não são de interesse, tais como albumina, imunoglobulinas das classes $M$ e $A$, além da transferrina, são retidas na primeira coluna. A imunoglobulina da classe $G$ é retida na segunda coluna contendo CM-Sepharose FF.

\subsubsection{Procedimentos de inativação viral e purificação final da IgG}

A solução de IgG é eluída da coluna CM-Sepharose FF com solução de cloreto de sódio 1M. Em seguida, a solução muito diluída de imunoglobulina da classe $\mathrm{G}$ é concentrada a $5 \%$ (peso por volume - w/v) com o auxílio de um sistema de filtros, modelo Pellicon Cassete 30.000 NMWL. O pH da solução de IgG é ajustado para 5,5 e em seguida, a preparação é submetida à inativação viral, segundo o método solvente/detergente proposto por HOROWITZ et al. (1985). No método de inativação utiliza-se tri(n-butil)fosfato $1 \%$ e Triton $X-100$, sob temperatura de $35^{\circ} \mathrm{C}$ por 10 horas. Posteriormente, esses reagentes químicos são removidos por cromatografia de troca iônica, processo no qual é usada uma coluna cromatográfica, modelo Index 200/500, contendo resina CMSepharose FF.

Após essa etapa de remoção do solvente/detergente, a solução de IgG é concentrada a 7\% (w/v), o pH ajustado para 4,0 e é adicionada pepsina $0,1 \mathrm{mg} / \mathrm{g}$ de proteína. A solução é, então, aquecida a $37^{\circ} \mathrm{C}$ por um período de 10 a 12 horas. Após essa etapa de aquecimento, a preparação com moléculas de IgG é resfriada a $20^{\circ} \mathrm{C}$ e, em seguida, aplicada a uma coluna cromatográfica, modelo BPG 200/950, contendo Sephacryl S-300 HR para remoção da pepsina e das moléculas de IgG agregadas ou polimerizadas que, eventualmente, sejam formadas no fracionamento. $O$ Sephacryl HR foi desenvolvido a partir de Sephacryl superfino já bem estabelecido. Portanto, a escolha da coluna contendo Sephacryl HR é um procedimento padrão na cromatografia de gel filtração. 
Após a eluição com uma mistura de acetato de sódio $0,1 \mathrm{M}$ e cloreto de sódio 50mM ( $\mathrm{pH} \mathrm{6,0),} \mathrm{a} \mathrm{solução} \mathrm{final} \mathrm{de} \mathrm{lgG,} \mathrm{composta} \mathrm{essencialmente}$ de moléculas monoméricas e com baixa atividade anticomplementar, é concentrada a 6,5\% (w/v) e o pH ajustado para 5,0 com ácido clorídrico 1M.

Em seguida, a solução é formulada pela adição de cloreto de sódio sólido, maltose $7,5 \%$ (w/v) e glicina $0,1 \mathrm{M}$. Esses reagentes são usados como estabilizadores das moléculas de IgG (FERNANDES e LUNDBLAD, 1980; McCUE, 1986). A preparação de IgG é esterilizada por filtração utilizando-se membranas sintéticas com especificação de porosidade $0,22 \mu \mathrm{m}$. O produto final é envasado em frascos de vidro inerte, capacidade $50 \mathrm{~mL}$.

\subsubsection{Determinações imunoquímicas}

Os testes imunoquímicos são realizados por: eletroforese usando-se como suporte o acetato de celulose (composição protéica), segundo a técnica descrita por VAZ et al. (1975); reações antígeno-anticorpo usando-se o micrométodo de Ouchterlony (1949) e imunoeletroforese utilizando-se soro antiproteína humana total e soro antiproteína animal de cavalo, vaca ou ovelha (prova de identidade) (GRABAR e WILLIAMS, 1953).

\subsubsection{Determinação das proteínas totais}

A concentração das proteínas totais é determinada pelo método do biureto (GORNALL et al., 1949), utilizando-se um aparelho de espectrofotometria, digital, com recursos para leituras de densidade óptica (absorbância) na região ultravioleta e na região visível (UV-VIS).

\subsubsection{Determinação do pH}

Para leituras de $\mathrm{pH}$ determinadas em potenciômetro $\left(20-25^{\circ} \mathrm{C}\right)$, as soluções de IgG são diluídas a 1\% com cloreto de sódio $0,9 \%$. 


\subsubsection{Determinação das hemaglutininas}

As hemaglutininas anti-A e anti-B são determinadas pelo teste de Coombs et al. (1945).

\subsubsection{Imunodifusão radial}

As presenças de imunoglobulinas da classe $A$ e da classe $M$ são realizadas por imunodifusão radial (The Binding Site Inc., San Diego, CA, USA).

\subsubsection{Determinação da atividade anticomplementar}

A atividade anticomplementar é determinada utilizando-se complemento de cobaia e hemácias de ovelha, segundo o método descrito na Farmacopéia Européia (1997) (MIELKA e GOZZE (1975).

\subsubsection{Determinação do ativador da pré-cralicreína}

O ativador da pré-calicreína (PKA) é determinado utilizando-se substrato cromogênico S2302 (Chromogenix, Mölndal, Suécia).

\subsubsection{Testes sorológicos}

A segurança contra microorganismos patogênicos, tanto no plasma coletado, como também na preparação final de lgG é avaliada através de testes sorológicos, tais como: anti-HIV, anti-HTLV 1 e 2, anti-HCV e AgHBs, utilizando-se as técnicas de ELISA, Western-Blot e PCR.

\subsubsection{Teste de esterilidade}

O teste de esterilidade é realizado pelo método de membranas filtrantes tipo Steritest (Sistema para Teste de Esterilidade, Millipore). 


\subsubsection{Teste de pirogênio}

Os testes para determinação de pirogênio e de toxicidade são feitos "in vivo", conforme recomendações feitas na Farmacopéia Americana (1995).

\subsubsection{Polímeros e agregados}

As porcentagens de distribuição dos monômeros, dímeros e polímeros são determinadas por cromatografia líquida de alta eficiência (CLAE), de acordo com a Farmacopéia Européia (1997).

\subsubsection{Determinação da atividade anticórpica}

Os títulos de anticorpos IgG anti-sarampo, anti-rubéola e anticaxumba são determinados por de imunofluorescência, reagentes Hemagen, segundo o método descrito por WELLER e COONS (1954).

\subsubsection{Teste de estabilidade}

O teste de estabilidade é realizado incubando-se a preparação de lgG a $57{ }^{\circ} \mathrm{C}$ por 4 horas e, após esse período, quando inspecionada visualmente, a mesma não deve apresentar alterações, tais como gelificação ou floculação na solução.

\subsubsection{Validação dos procedimentos}

Os estudos de validação dos procedimentos de produção e controle de qualidade são da responsabilidade de cada fabricante e devem ser específicos para cada estágio dos processos (WHO, 1982).

Os estudos de validação devem ser designados para justificar as condições de operações selecionadas e as faixas de aceitação toleradas, bem como para documentar suas adequações para concluir com êxito as performances esperadas nos processos (WHO, 1992). Particularmente, os processos que utilizam técnica de separação e purificação de proteínas por cromatografia em coluna devem promover investigações mais cuidadosas na 
busca da validação do método, com especial atenção nos procedimentos de limpeza e regeneração das colunas, para não ocorrer contaminações por resíduos, provenientes de separações anteriores ou de reagentes usados, tais como solvente/detergente (WHO, 1994).

Todos os processos de produção, controle de qualidade e especificações do produto final devem ser muito bem documentados e toda documentação deve ser mantida no mínimo por 2 anos.

Nas Figuras 5, 6, 7 e 8 apresentamos os equipamentos utilizados na unidade experimental da Fundação Pró-Sangue para obtenção de albumina, IgG e fatores VIII e IX da coagulação. Na Figura 9 apresentamos os produtos derivados de plasma humano, fracionados por cromatografia em coluna.

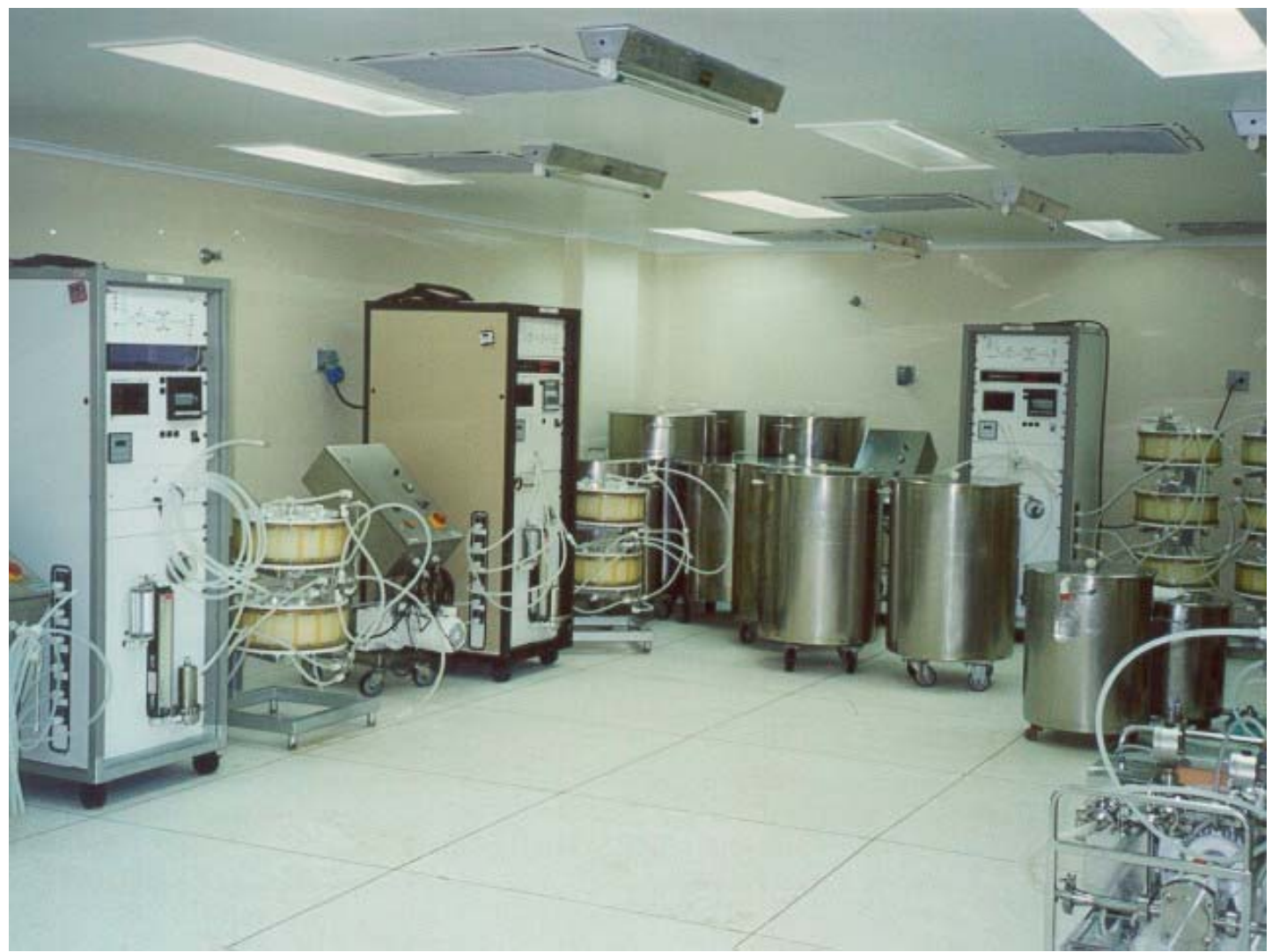

Figura 5 - Área estéril, sistemas cromatográficos automatizados e tanques de aço inoxidáveis usados na separação e purificação de albumina e IgG humana. 


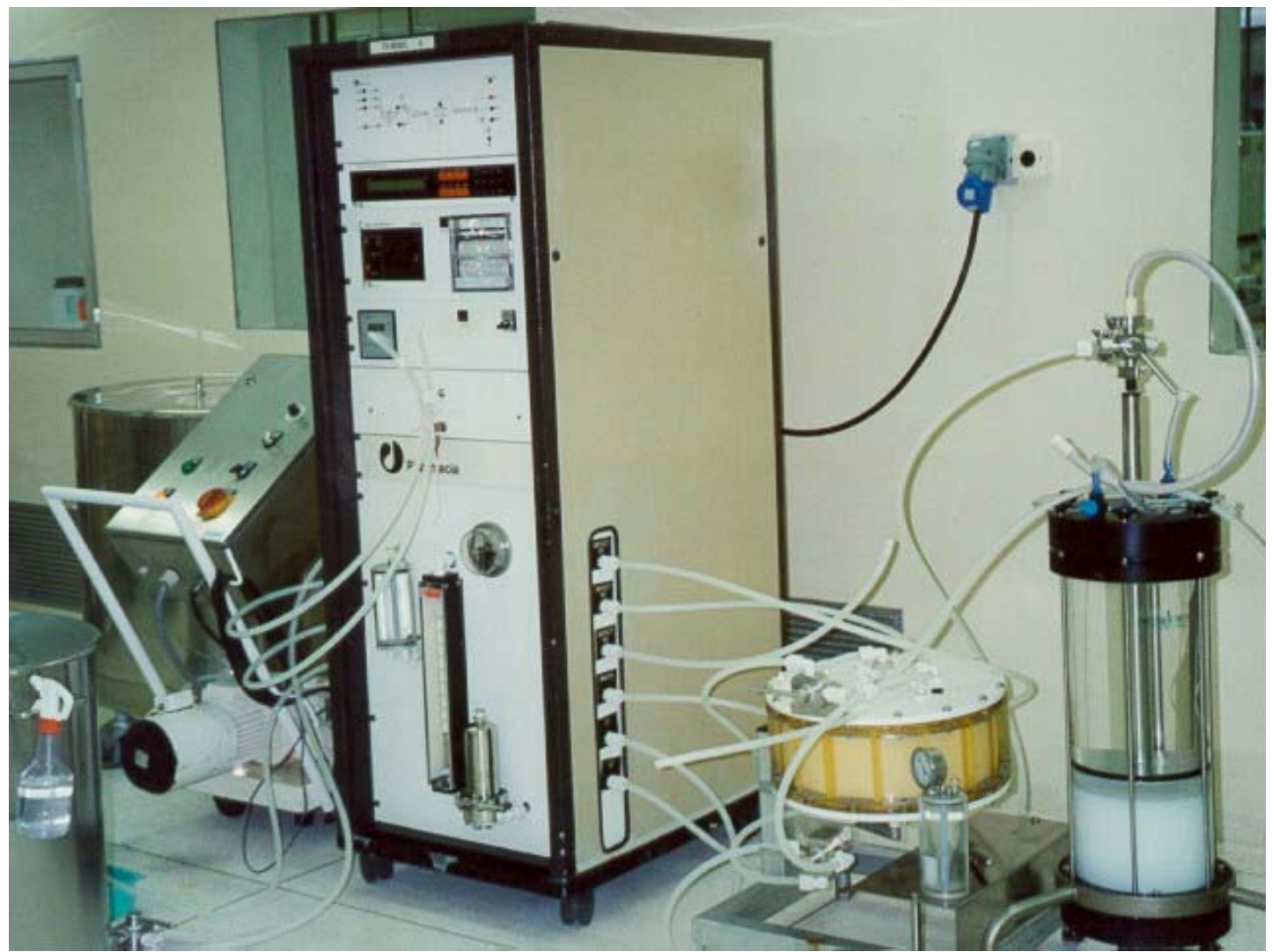

Figura 6 - Sistema cromatográfico em coluna, contendo gel de troca iônica Q-Sepharose FF e CM-Sepharose FF, para purificação intermediária de IgG. 


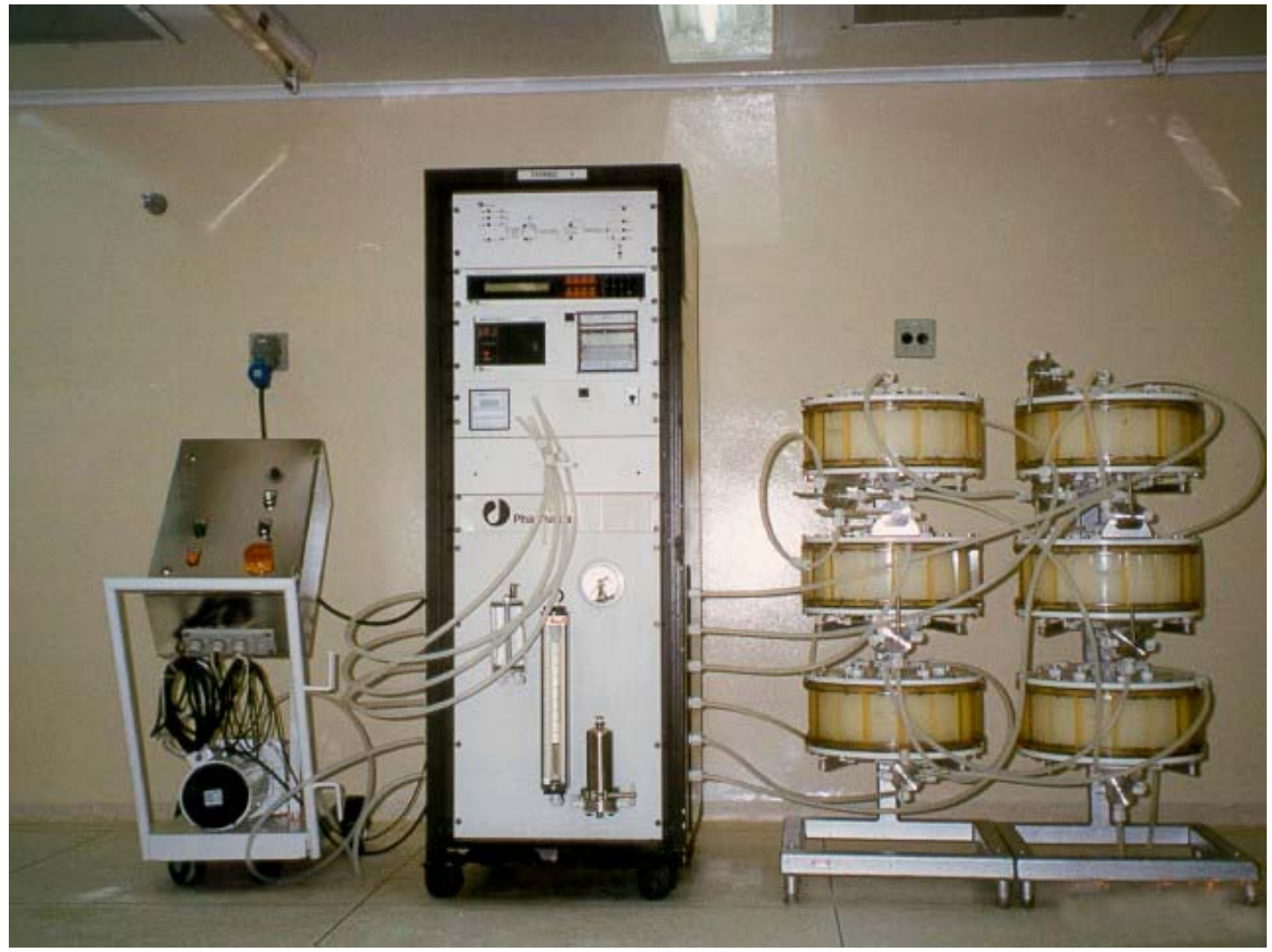

Figura 7 - Sistema cromatográfico em coluna, contendo gel de filtração Sephacryl S-200 HR, para purificação final de albumina. 


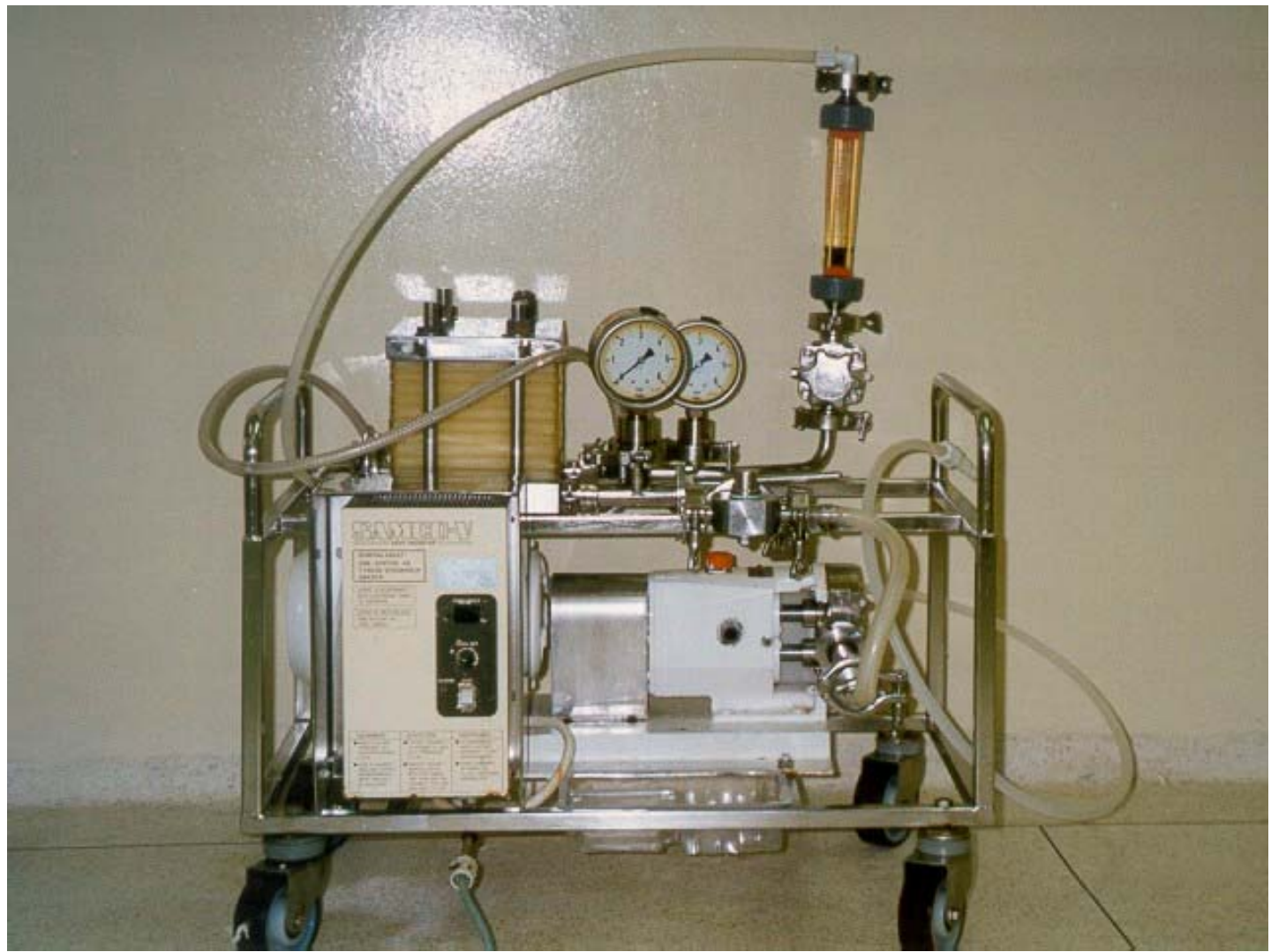

Figura 8 - Sistema de filtros Peliicon Cassete 30.000 NMWL para concentração e ultrafiltração da solução de IgG. 


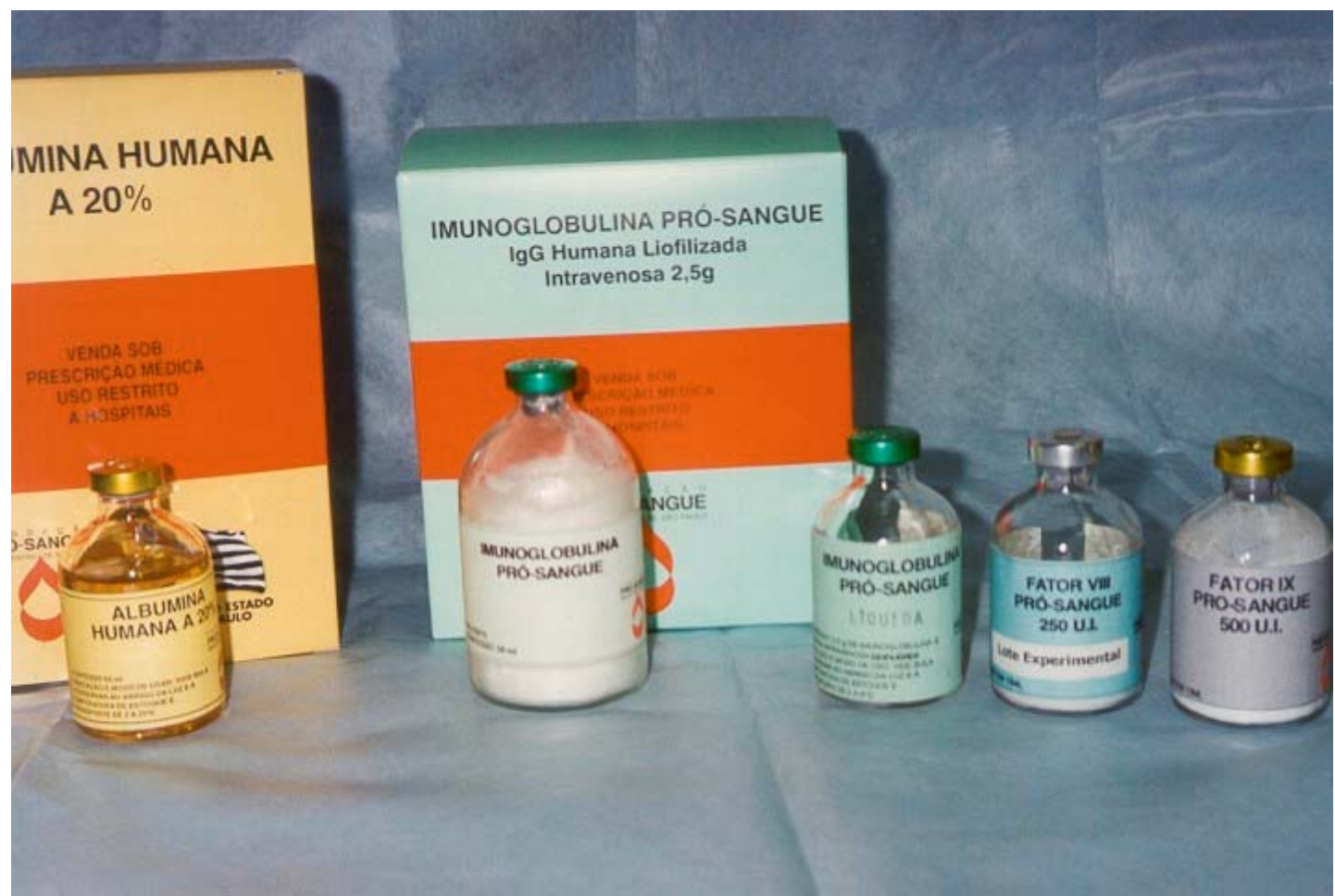

Figura 9 - Albumina, IgG liofilizada, solução de IgG, fatores VIII e IX da coagulação fracionados por cromatografia em coluna a partir de plasma humano. 
4. RESULTADOS 
No presente estudo comparativo realizado com preparações de imunoglobulina da classe $G$ para uso humano, por via de administração intravenosa, as concentrações de $\lg$ e as distribuições das subclasses IgG1, IgG2, IgG3 e IgG4 estão apontadas na Tabela 3.

$\mathrm{Na}$ preparação 1, observamos que a concentração total da lgG foi menor do que $1 \%$ (mais precisamente $0,82 \%$ ), muito abaixo do valor mínimo de $3 \%$ estabelecido pelas normas internacionais para obtenção de IgG. Em conseqüência, as concentrações das subclasses lgG1, IgG2, IgG3 e IgG4 também ficaram abaixo dos valores mínimos detectáveis pelo método analítico (ELISA), cujos limites mínimos de sensibilidade são: $\operatorname{lgG} 1=$ $0,42 \mu \mathrm{g} / \mathrm{L} ; \operatorname{lgG} 2=7,35 \mu \mathrm{g} / \mathrm{L} ; \operatorname{lgG} 3=0,29 \mu \mathrm{g} / \mathrm{L} ; \lg G 4=0,44 \mu \mathrm{g} / \mathrm{L}$. Por outro lado, apesar da preparação 5 ter apresentado concentração de IgG igual a $7,02 \%$, a maior concentração verificada entre todas as imunoglobulinas analisadas, a concentração da subclasse lgG3 apresentou-se abaixo do valor mínimo detectável pelo método (IgG3 abaixo de $0,29 \mu \mathrm{g} / \mathrm{L}$ ) nesta amostra.

A concentração total de IgG na preparação 8 ficou abaixo do valor mínimo esperado, mas a distribuição das suas subclasses apresentou-se compatível com os valores de referência encontrados no plasma humano normal. As demais preparações de imunoglobulinas (2, 3, 4, 6, 7, 9 e 10) apresentaram concentrações de IgG dentro da faixa esperada de 3-18\%, e a distribuição das subclasses $\lg G 1$, IgG2, IgG3 e $\lg G 4$ apresentou-se compatível com os valores de referência no plasma normal: IgG1: 60-70 \%; IgG2: 14-20\%; IgG3: 4-8\% e IgG4: 2-6\%. 
Tabela 3 Distribuição das subclasses $\lg G 1, \lg G 2$, $\lg G 3$ e $\lg G 4$ (\% do total de $\lg G$ ) e determinação quantitativa da concentração protéica (\%) em lotes de preparações de imunoglobulinas para uso humano por via de administração intravenosa.

\begin{tabular}{c|cccc|c}
\hline & $\lg G 1(\%)$ & $\operatorname{lgG}(\%)$ & $\operatorname{lgG}(\%)$ & $\lg G 4(\%)$ & $\lg (\%)$ \\
\hline 1 & $*$ & $*$ & $*$ & $*$ & 0,82 \\
2 & 60 & 23 & 7 & 3 & 5,50 \\
3 & 52 & 23 & 6 & 3 & 6,92 \\
4 & 53 & 20 & 5 & 3 & 3,62 \\
5 & 60 & 22 & $*$ & 2 & 7,02 \\
6 & 60 & 23 & 5 & 2 & 5,97 \\
7 & 62 & 23 & 5 & 2 & 5,55 \\
8 & 64 & 20 & 4 & 5 & 2,42 \\
9 & 62 & 20 & 6 & 3 & 6,00 \\
10 & 60 & 20 & 4 & 6 & 5,14 \\
\hline Misturas & 70 & 20 & 7 & 4 & 1,20 \\
de plasma humano & & & & & \\
\hline 2* & & & &
\end{tabular}

2 * Abaixo dos limites de sensibilidade do método Faixas de referência: IgG1 (60-70\%); IgG2 (14-20\%); IgG3 (4-8\%); IgG4 (2-6\%) (BASSION, 1989; JEFFERIS e KUMARATNE, 1990). 
Nas preparações de IgG, a determinação qualitativa dos anticorpos contra os vírus HIV, HTLV I/II, HCV, HBV, HAV, a determinação do antígeno de superfície do vírus $B$, a determinação do ácido nucléico (DNA) do Parvovírus B19, a determinação dos anticorpos IgG anti-T.pallidum e a determinação de anticorpos anti-lipídicos (reaginas ou anticorpos não treponêmicos) estão apresentadas na Tabela 4, 5 e 6 . Em todas as preparações estudadas não foram detectados anticorpos para o vírus HIV.

Na totalidade das preparações examinadas por PCR, também não foi registrada a presença de DNA genômico do Parvovírus B19.

Pela técnica de ELISA, as preparações 1, 2, 3, 7, 8 e 9 (60\% das preparações) apresentaram resultados positivos na detecção de anticorpos IgG para o vírus HTLV I/II. Entretanto, por Western Blot, pudemos observar que a amostra 1 estava de fato negativa. Nas preparações 4, 5, 6 e 10 (40\%) não foi detectada por ELISA a presença de anticorpos contra o HTLV. Nas preparações 2, 7, 8 e 9, os resultados dos anticorpos contra o HTLV foram indeterminados (Tabela 4) e, somente a preparação 3 apresentou as frações antigênicas características de soropositividade (Tabela 5). De acordo com o fabricante do conjunto diagnóstico utilizado, as frações antigênicas do HTLV I/II que indicam soropositividade são: reagente para gag (p19 com ou sem p24) e duas bandas env (GD21 e rgp46-I); reagente para gag (p24 com ou sem p19) e duas bandas env (GD21 e rgp46-II); reagente para gag (p19 e p24) e env (GD21) (Tabela 5). Nas preparações de IgG que apresentaram resultados indeterminados não foram realizados testes por biologia molecular, pois atualmente, os mesmos não estão disponíveis para os laboratórios de sorologia dos bancos de sangue brasileiros.

Utilizando-se dois diferentes conjuntos diagnósticos por ELISA e um outro conjunto por Western Blot foram detectados anticorpos IgG contra o vírus da hepatite $\mathrm{C}(\mathrm{HCV})$ na preparação 8. Porém, não foi encontrado o material genético do vírus (HCV-RNA) por PCR nessa preparação. 
Tabela 4 Testes sorológicos realizados em preparações de lgG (uso humano) de variadas procedências para a determinação qualitativa dos anticorpos IgG contra os vírus: HIV (ELISA I e II); HTLV I/II (ELISA I e II; WB IV); HCV (ELISA I e III; IB II) e para determinação do material genético (DNA) do Parvovírus B19 (PCR).

\begin{tabular}{|c|c|c|c|c|c|c|c|c|}
\hline & anti- & anti- & anti- & anti- & anti- & anti- & anti- & Parvo \\
\hline & HIV & HTLV & HTLV & HTLV & $\mathrm{HCV}$ & $\mathrm{HCV}$ & $\mathrm{HCV}$ & Vírus \\
\hline & ( $|\mathrm{e}| \mathrm{ll})$ & (I) & (II) & (IV) & (I) & (III) & (II) & B19 \\
\hline 1 & $(-)$ & + & $(-)$ & $(-)$ & $(-)$ & $(-)$ & $(-)$ & $(-)$ \\
\hline 2 & $(-)$ & + & + & Ind & $(-)$ & $(-)$ & $(-)$ & $(-)$ \\
\hline 3 & $(-)$ & + & + & + & $(-)$ & $(-)$ & $(-)$ & $(-)$ \\
\hline 4 & $(-)$ & $(-)$ & $(-)$ & $(-)$ & $(-)$ & $(-)$ & $(-)$ & $(-)$ \\
\hline 5 & $(-)$ & $(-)$ & $(-)$ & $(-)$ & $(-)$ & $(-)$ & $(-)$ & $(-)$ \\
\hline 6 & $(-)$ & $(-)$ & $(-)$ & $(-)$ & $(-)$ & $(-)$ & $(-)$ & $(-)$ \\
\hline 7 & $(-)$ & + & + & Ind & $(-)$ & $(-)$ & $(-)$ & $(-)$ \\
\hline 8 & $(-)$ & + & + & Ind & + & + & + & $(-)$ \\
\hline 9 & $(-)$ & + & + & Ind & $(-)$ & $(-)$ & $(-)$ & $(-)$ \\
\hline 10 & $(-)$ & $(-)$ & $(-)$ & $(-)$ & $(-)$ & $(-)$ & $(-)$ & $(-)$ \\
\hline
\end{tabular}

\footnotetext{
${ }^{3}$ Resultados: (-) negativo + positivo ind: indeterminado Técnicas: IB: Imunoblot ELISA: Enzimaimunoensaio PCR: Reação em cadeia da polimerase

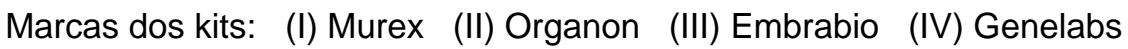


Tabela 5 Determinação das frações antigênicas do vírus HTLV I/II por Western Blot que indicam soropositividade nas preparações de imunoglobulinas $\mathrm{G}$ para uso humano por via intravenosa ${ }^{4}$.

\begin{tabular}{c|ccc}
\hline Preparações & p19 & p24 & GD21 \\
\hline 1 & $(-)$ & $(-)$ & $(-)$ \\
2 & $(-)$ & + & $(-)$ \\
3 & + & + & + \\
4 & $(-)$ & $(-)$ & $(-)$ \\
5 & $(-)$ & $(-)$ & $(-)$ \\
6 & $(-)$ & $(-)$ & + \\
7 & $(-)$ & $(-)$ & + \\
8 & $(-)$ & $(-)$ & + \\
9 & $(-)$ & $(-)$ & $(-)$ \\
\hline
\end{tabular}

\footnotetext{
${ }^{4}$ De acordo com as especificações do fabricante do conjunto diagnóstico utilizado
} 
Em todas as preparações de IgG estudadas (100\%) não foi encontrado o primeiro marcador sorológico da infecção pelo HBV, o antígeno de superfície da hepatite B (AgHBs) (Tabela 6). Por outro lado, os testes realizados por ELISA para a detecção de anticorpos contra o antígeno de superfície (anti-HBs) e contra o antígeno do core (anti-HBc) apresentaram resultados positivos em todas as preparações, exceto a preparação 10 que apresentou resultado negativo na detecção de anticorpos anti-HBc.

Nas análises das preparações, encontramos resultados positivos na detecção de anticorpos lgG , característicos da fase de imunização, contra o vírus da hepatite A (HAV). Por outro lado, as preparações 3 e 7 apresentaram resultados positivos nos testes na detecção de anticorpos da classe IgM, característicos da fase aguda da doença, contra o HAV. A preparação 10 apresentou resultado indeterminado para o anticorpo $\lg \mathrm{M}$ anti-HAV (Tabela 6).

A preparação 9, por ELISA e FTA-ABS para a detecção dos anticorpos IgG contra o agente causador da sífilis ( $T$. pallidum) e por VDRL para detecção de reaginas, apresentou resultados positivos em todos os testes realizados (Tabela 6). Nas preparações 1 e 8, encontramos resultados positivos nos testes realizados por ELISA, porém, nos testes realizados por VDRL e FTA-ABS, os resultados foram negativos. Por outro lado, as preparações 2, 3 e 7 apresentaram resultados positivos por ELISA e FTAABS para anticorpos IgG contra o agente da sífilis, mas resultados negativos por VDRL para anticorpos anti-cardiolipina (ou reaginas ou anticorpos nãotreponêmicos). Somente em 40\% das preparações estudadas (4, 5, 6 e 10) não foram detectados anticorpos IgG contra o T. pallidum e anticorpos anticardiolipina. 
Tabela 6 Testes sorológicos realizados em preparações de lgG (uso humano) de variadas procedências para determinação do antígeno de superfície AgHBs (ELISA II); determinação qualitativa dos anticorpos da classe IgG contra os vírus: HBV (ELISA (anti-HBs) I; (anti-HBc) II) ; HAV (ELISA anti-HAV (IgG) II; anti-HAV (IgM) II); determinação dos anticorpos anticardiolipina (VDRL V) e anti-T.pallidum (ELISA I e II, FTA-ABS $\mathrm{VI})$.

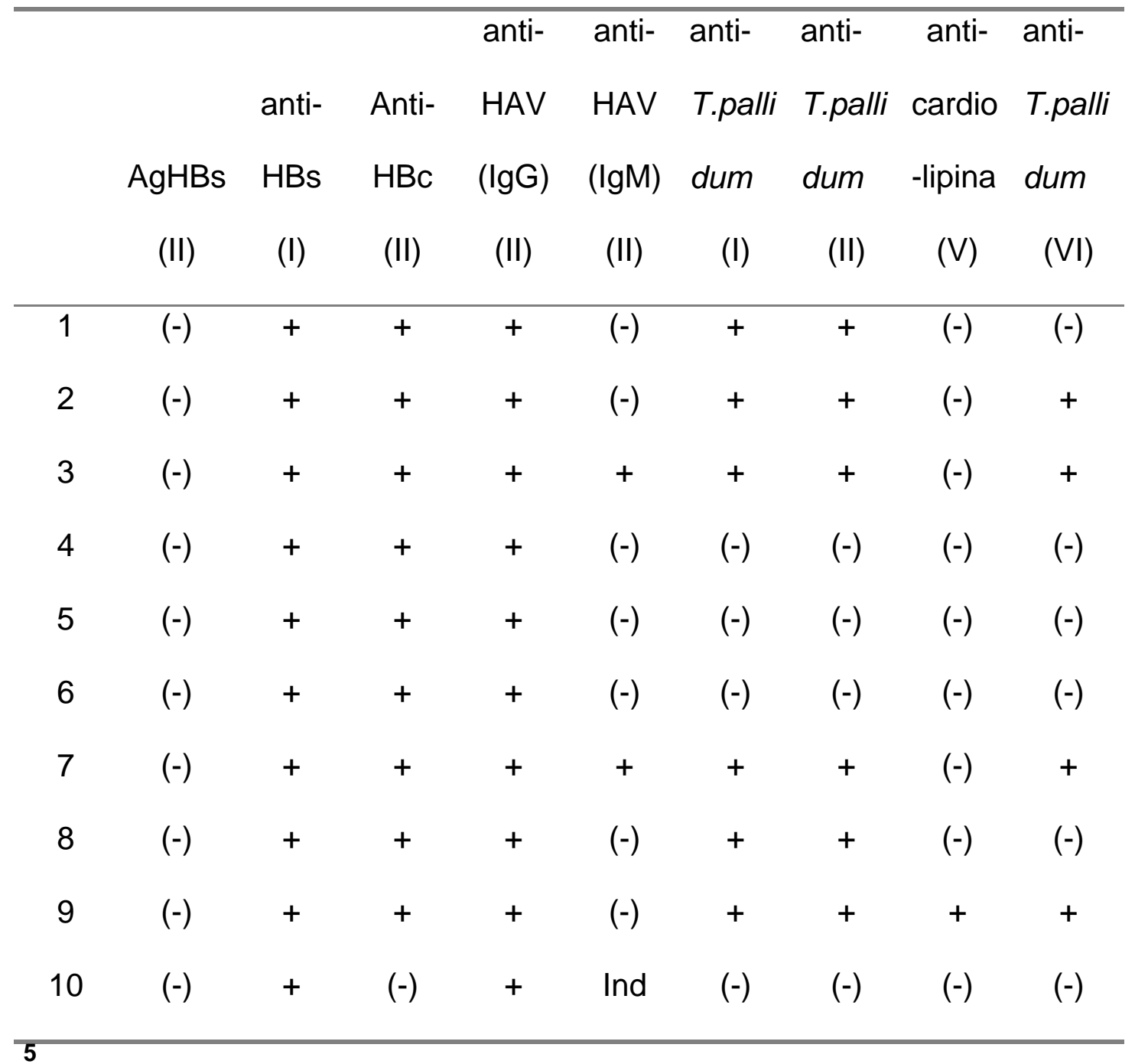

\footnotetext{
${ }^{5}$ Resultados: (-) negativo + positivo ind: indeterminado Técnicas: WB: Western Blot ELISA: Enzimaimunoensaio VDRL: Teste de floculação FTA - ABS: Imunofluorescência Marcas dos kits: (I) Murex (II) Organon (V) Laborclin (VI) Biolab
} 
As determinações qualitativas dos anticorpos IgG contra os vírus: da rubéola, citomegalovírus, herpes simples, anticorpos IgG contra a bactéria Chlamydia trachomatis, anticorpos IgG contra o parasita Toxoplasma gondii e anticorpos lgG anti-estreptolisina O (ASLO) em preparações de IgG estão apresentadas na Tabela 7. Em todas as preparações analisadas (100\%) por imunofluorescência, não foi detectada atividade dos anticorpos IgG antiChlamydia trachomatis.

Por outro lado, foi detectada atividade dos anticorpos IgG anti-SLO (ASLO) nas preparações 1, 2, 3, 5, 6, 7, 8, 9 e 10 (cerca de 90\%) e anticitomegalovírus em todas as preparações, exceto na preparação 1. Foi detectada atividade anti-herpes simples nas preparações 1, 2, 3, 4, 7, 8 e 9, porém, não foram detectados esses anticorpos nas preparações 5, 6 e 10.

Verificamos, ainda, a presença de atividade dos anticorpos IgG para o vírus da rubéola e para o parasita Toxoplasma gondii, causador da toxoplasmose, em todas as preparações analisadas por ELISA, conforme os dados mostrados na Tabela 7. 
Tabela 7 Atividade de anticorpos específicos anti-estreptolisina $\mathrm{O}$ (ASLO); anti-rubéola; antitoxoplasmose; anti-Chlamydia trach.; anti-citomegalovírus (CMV) e anti-herpes simples (1 e 2) em preparações de $\lg G$, obtidas a partir de misturas de plasma humano de, no mínimo, 1.000 doadores.

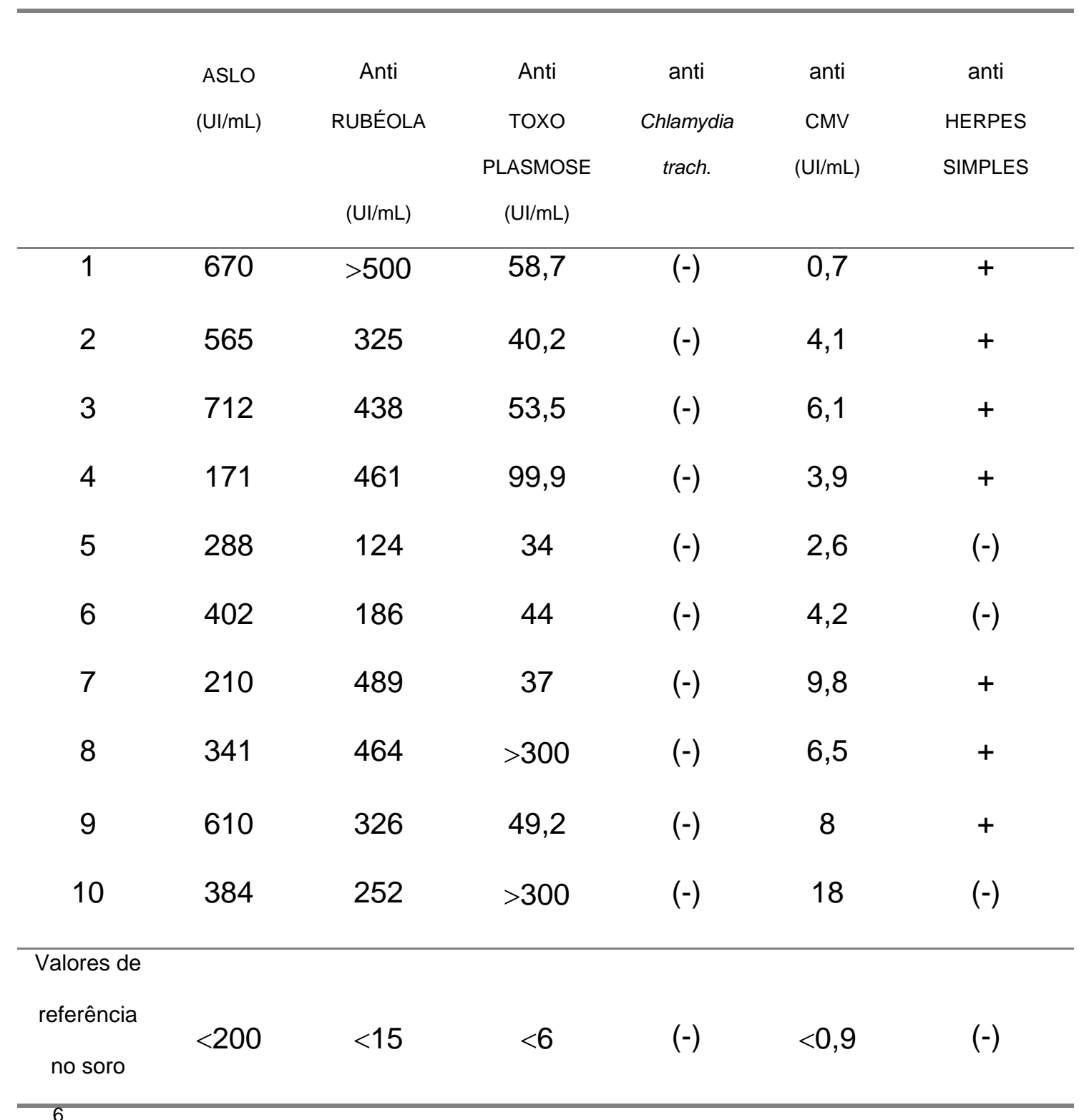

${ }^{6}$ Resultados: (-) negativo + positivo Ul/mL: Unidades Internacionais por mililitro Os valores de referência no soro foram obtidos da literatura. 
5. DISCUSSÃO 
A qualidade e a segurança das preparações de $\lg G$ depende diretamente da rigorosa seleção dos doadores, rigorosa seleção da matériaprima (plasma), dos processos de fracionamento e dos processos de eliminação viral. No Brasil, ainda não foi realizado nenhum estudo demonstrando a qualidade e a segurança das preparações de IgG importadas e disponíveis para uso humano.

Em nosso país, as preparações de IgG, bem como albumina humana e fatores VIII e IX da coagulação são processadas em caráter experimental para pesquisa, desenvolvimento e formação de pessoal altamente qualificado, somente pela Fundação Pró-Sangue Hemocentro de São Paulo. Em Recife, há uma outra planta experimental em operação, mas, atualmente, somente para obtenção de albumina humana.

No Brasil, não existe nenhuma unidade industrial capaz de processar quantidades suficientes para suprir todas as necessidades da nossa população por esses hemoderivados. Segundo os responsáveis pela da Agência Nacional de Vigilância Sanitária (NETO, 2001), órgão responsável pelo controle e fiscalização na área de sangue e hemoderivados: "somente em médio prazo, será estudada a construção de fábrica(s) nacional(is) para obtenção de hemoderivados".

Recentemente, fomos informados que a preparação 1, usada no presente estudo comparativo, não é mais fracionada pelo fabricante, em outras palavras, o processo de obtenção desse produto foi descontinuado. Segundo relatos do fabricante, os lotes de $\operatorname{lgG}$ obtidos não apresentavam especificações adequadas de qualidade. Porém, cabe ressaltar que durante muito tempo, pela ausência de um programa nacional de qualidade, padronizado e eficiente, para hemoderivados obtidos por fracionamento industrial, essas preparações foram largamente empregadas na clínica médica, possivelmente sem causar os efeitos terapêuticos desejados.

Assim também, muitas preparações de imunoglobulinas encontradas no mercado nacional podem não ser muito eficazes clinicamente, simplesmente por não possuírem um largo espectro de atividades anticórpicas específicas a nossa população ou concentrações não 
adequadas das subclasses $\lg G 1$, IgG2, IgG3 e IgG4.

Desse modo, a partir dos resultados obtidos em nosso estudo comparativo, pudemos avaliar alguns importantes parâmetros de qualidade de produtos fracionados do sangue por processos industriais. Para realização de todos os nossos experimentos laboratoriais, utilizamos um frasco de um único lote de cada uma das preparações de IgG estudadas. Cada lote representa misturas de plasmas de 1.000 a 10.000 doadores. Em tese, a mistura desses milhares de unidades de plasmas deve ser proveniente de doadores normais (saudáveis). Assim, levando-se em consideração ser muito grave a transmissão de agentes patogênicos pelo sangue ou produtos derivados, bastaria um único frasco com indicações de matéria-prima contaminada para comprometer todo lote.

\subsection{Concentrações de IgG e distribuição das subclasses IgG1, IgG2, $\lg G 3$ e IgG4}

Nossos resultados mostraram importantes diferenças nas concentrações de IgG e na distribuição das subclasses lgG1, IgG2, IgG3 e IgG4 em algumas das preparações estudadas.

A redução na concentração de IgG total ou de suas subclasses, abaixo dos níveis normais estabelecidos pelas normas internacionais, pode ocorrer devido às etapas de separação, purificação ou de inativação viral que, se não forem controladas de modo adequado, certamente afetam o produto final. Nos processos de fracionamento escolhidos por cada fabricante, vários fatores, tais como composição da solução, temperatura, pH do meio, centrifugação, ultrafiltração e contaminações por reagentes químicos, se não forem muito bem conhecidos e controlados, podem degradar as porções Fab e Fc das moléculas de imunoglobulinas, formar polímeros e agregados, ativar pró-enzimas, inativar inibidores e promover significativas mudanças conformacionais (estabilidade globular das moléculas de IgG) (CURLING, 1983). Todas essas alterações nas moléculas tornam as preparações de IgG ineficazes para o uso terapêutico ou podem ainda causar várias reações adversas nos pacientes, entre as quais, febre, 
choques anafiláticos, reações alérgicas e alguns efeitos inflamatórios graves, inclusive nas meninges (BUSSEL e HILGARTNER, 1984; REWALD e MORELL, 1993).

Como observado por CHAMONE. (comunicação pessoal) e BUSSEL (2000), muitos pacientes portadores de Púrpura Trombocitopênica Idiopática mostraram resultados clínicos insatisfatórios durante o tratamento com imunoglobulinas fragmentadas. Objetivamente, os autores verificaram a ineficácia terapêutica desses produtos através da contagem de plaquetas dos pacientes em tratamento, que não apresentaram aumento significativo no número dessas células.

Além da desnaturação das moléculas protéicas, pode também ocorrer redução nos níveis de anticorpos presentes devido a perdas nas várias etapas de processamento. O nosso estudo mostrou que, apesar da preparação 5 ter apresentado a maior concentração de IgG em comparação às outras preparações, possivelmente, ocorreu alguma etapa no fracionamento da imunoglobulina $G$ que foi realizada de modo inadequado, justificando-se, assim, o fato da concentração de lgG3 ter ficado abaixo do nível normal, em comparação aos níveis normais encontrados no soro humano

De modo semelhante, a preparação 1 ilustra claramente que 0 método de fracionamento utilizado não foi ideal, pois as concentrações de IgG e das subclasses ficaram abaixo do valor mínimo normal. Apesar de ter sido usada por mais de duas décadas, temos conhecimento que, muito recentemente, o processo de fracionamento da preparação em questão foi interrompido.

Por outro lado, na preparação 8 proveniente da Índia, as baixas concentrações de $\lg G$ e das subclasses encontradas demonstram que algumas etapas de fracionamento podem ter sido realizadas de modo inadequado, contudo, é muito factível afirmar-se também que, a matériaprima utilizada foi de baixa qualidade protéica, ou seja, os doadores selecionados para a coleta de plasma apresentavam níveis de proteínas totais abaixo dos limites padrões aceitáveis para doação de sangue. 


\subsection{Qualidade das preparações de IgG}

\subsubsection{Segurança da matéria-prima}

Embora nas últimas décadas, consideráveis avanços tecnológicos tenham sido feitos nos processos de separação, purificação e inativação viral de proteínas derivadas do plasma, os mesmos estão em permanente aprimoramento, por isso, as opiniões sobre quais os processos ideais de fracionamento ainda são muito divergentes. Entretanto, é incontestável que as preparações de lgG para uso clínico devem ser obtidas por tecnologias capazes de garantir produtos que, entre outras qualidades, sejam seguros contra a transmissão de vários agentes patogênicos. Essa garantia de qualidade inicia-se pela matéria-prima que deve ser rigorosamente controlada desde a seleção do doador.

A qualidade do plasma fresco ou do plasma congelado pode ser influenciada por alguns fatores, tais como composição e pH do anticoagulante usado, mudanças de $\mathrm{pH}$ durante a coleta e armazenamento e velocidade de congelamento. Tais fatores podem reduzir a atividade biológica de alguns componentes do plasma ou, de modo inverso, ativar outros capazes de causar reações adversas nos pacientes tratados com esses produtos. Assim, para obtenção de uma lgG de excelente qualidade, esses parâmetros técnicos iniciais devem ser muito bem estabelecidos e controlados (MORELL, 1986).

Outro fator importante que deve ser controlado desde o princípio, é a contaminação do sangue ou componentes por bactérias. Para evitar os riscos de contaminações bacterianas, procedimentos rigorosos de assepsia devem ser aplicados tanto ao pessoal quanto aos materiais de coleta do sangue. Em seguida, as bolsas coletadas devem ser armazenadas adequadamente em temperatura controlada que pode variar entre 1 a $6{ }^{\circ} \mathrm{C}$.

O controle para os riscos de contaminação por agentes virais também requer muito rigor por parte das autoridades de saúde pública e dos centros fracionadores, pois, apesar dos grandes avanços tecnológicos conseguidos na área de fracionamento, uma grande quantidade de estudos publicados na 
literatura tem revelado que as preparações de IgG ainda apresentam graves riscos de transmissão, não só por bactérias, mas também por outros agentes, tais como vírus da hepatite B (HBV) e C (HCV) (NAKAMURA e SATO, 1976; YAP, 1991; YU et al., 1994; SUOMELA, 1995). Além disso, outros vírus pouco conhecidos também podem ser fontes de contaminação ainda não bem elucidas (TAN et al., 1999).

BRESEE et al. (1996), através de um estudo retrospectivo, fizeram alguns relatos sobre uma determinada preparação de IgG responsável pela contaminação de vinte e três pacientes com o vírus da hepatite $\mathrm{C}(\mathrm{HCV})$, após o tratamento com a medicação por via intravenosa. Em 1996, DODD também publicou um estudo mostrando a relação entre os riscos de infecção viral via plasma doado e a segurança das preparações de imunoglobulinas.

Todo o plasma utilizado no fracionamento de proteínas tem sua segurança básica na doação de sangue, desta forma, além das normas técnicas estabelecidas para seleção de doadores de sangue (triagem clínica e epidemiológica - Anexo B), a triagem sorológica tem um papel fundamental na prevenção das doenças transmissíveis pelo sangue e componentes. Além da rigorosa seleção dos doadores e da matéria-prima, também os processos de inativação viral são de fundamental importância e, por isso, devem ser muito eficientes, a fim de garantir produtos livres de contaminações microbianas (HOROWITZ et al., 1985).

Nos Estados Unidos, os riscos de transmissão viral pelo sangue e produtos derivados foram avaliados em: HIV (1:300.000) (KANKI e DE COCK, 1994); HTLV I/II (1:70.000) (CANAVAGGIO et al., 1990); HBV (1:200.000) (USHIDA et al., 1994) e HCV (1:60.000) (DODD, 1996; CHAMBERLAND, 1999).

Os índices de soroprevalência de infecção por HTLV I/II encontrados entre os doadores de sangue assintomáticos brasileiros têm oscilado em cerca de 0,3\% em São Paulo (ALQUEZAR et al., 1992) e de 1,1\% em Salvador (MOREIRA et al., 1993). Em 1993, os índices de soroprevalência para o HBV variaram de 0,65 a 1,31\%, sendo que o índice maior foi observado na região sul do país (SÁEZ-ALQUÉZAR et al., 1994). Nesse 
mesmo ano, os índices para o HCV variaram de 1,2 a 2,3\%, este último verificado na região norte (SÁEZ-ALQUÉZAR et al., 1994).

No Brasil, graças à Portaria MS n 1.376 de 19 de novembro de 1993 para a coleta de sangue, foram estabelecidos rigorosos testes sorológicos obrigatórios para a pesquisa da Doença de Chagas, sífilis, hepatites B e C, síndrome da imunodeficiência adquirida (SIDA/AIDS), HTLV I/II. Além da determinação dos níveis séricos de atividade enzimática da alanina aminotransferase (ALT), os testes utilizados para detectar AgHBs, anticorpos anti-HBc, anti-HCV, anti-HTLV I/II, HIV 1 e 2, anti-T. pallidum e anti-T. cruzi devem apresentar alta sensibilidade de modo a evitar-se, ao máximo, o aparecimento de falsos resultados negativos, visando assim, em primeira instância, a segurança do receptor. Como nem sempre a especificidade acompanha os índices da sensibilidade, verifica-se a ocorrência de grande número de falsos resultados positivos.

Devido a essas características, torna-se necessário que os resultados dos testes sorológicos para deteç̧ão de anticorpos lgG inicialmente positivos e que, em princípio, levam à não utilização das bolsas correspondentes, sejam confirmados para se ter certeza de quais doadores de sangue realmente estão infectados. Assim, é possível informá-los corretamente e encaminhá-los a serviços especializados que possam prestar aconselhamento e seguimentos adequados (SÁEZ-ALQUÉZAR et al., 1996).

Atualmente, os testes que pesquisam anticorpos IgG contra determinados agentes patogênicos, quando utilizados como critérios de seleção, estão sendo muito discutidos e o enfoque dessa discussão é de muita relevância, pois, muitas vezes, a presença desses anticorpos refere-se a infecções passadas e já tratadas. Contudo, na impossibilidade de outros critérios de seleção mais específicos e enquanto o método de reação em cadeia da polimerase (PCR) não estiver totalmente padronizado e disponível para uso rotineiro em laboratórios de triagem sorológica, os testes sorológicos que detectam anticorpos IgG permanecem desempenhando sua função de selecionar doadores de sangue, mesmo que os agentes patogênicos não estejam mais presentes no organismo do doador. 
Assim, seguindo todos os critérios estabelecidos pela Portaria 1.367, na Fundação Pró-Sangue, a qualidade do plasma utilizado no fracionamento de proteínas foi garantida e a rigorosidade na coleta da matéria-prima apontou reflexos diretos na obtenção das preparações finais de IgG, que apresentaram resultados negativos em todas as provas sorológicas obrigatórias.

Por outro lado, com base nos resultados dos testes sorológicos realizados em todas as preparações de IgG nesse estudo comparativo, podemos considerar que a qualidade da matéria-prima utilizada na obtenção da preparação 8 (proveniente da Índia) não é aceitável, pois, apesar da mesma ter apresentado resultados positivos para anticorpos anti-HCV através das técnicas de ELISA e Western Blot, mas negativo quanto à determinação do ácido nucléico (RNA) do vírus por PCR, desconhecemos se nesse produto estariam presentes outros tipos de vírus da família Flaviviridae, isto é, outros vírus da mesma família na qual o HCV está classificado (McFARLANE et al., 1990; WONG et al., 1990).

SIMONS et al. (1995) relataram a presença de outros vírus como da hepatite $\mathrm{G}$ em amostras de soro de pacientes pós-transfundidos. Em 1997, NISHIZAWA et al. isolaram, no soro de um paciente pós-transfundido, a presença de DNA genômico do TTV vírus e, as implicações clínicas dessas contaminações ainda são pouco conhecidas. Como os mecanismos de detecção dos anticorpos contra esses vírus são ainda pouco conhecidos, é possível que eles possam interferir nas reações de detecção de anticorpos anti-HCV por ELISA, sugerindo resultados falso-positivos.

Embora não haja nenhuma evidência científica comprovando a transmissão do agente causador da Doença de Creutzfeldt-Jakob (CJD), o príon, por transfusões sangüíneas ou pelo uso de produtos fracionados do sangue como as imunoglobulinas, a albumina e os fatores de coagulação, é imprescindível obter-se mais informações sobre os riscos de transmissão e sobre os meios de detecção desse agente. Segundo um estudo feito por DODD (1996), sabe-se que o príon é muito resistente a alguns dos processos de inativação rotineiros. 
Por outro lado, a ausência de anticorpos determinados no plasma por ELISA, pode deixar passar a presença do próprio vírus, pois existe um período de tempo, denominado janela imunológica em que, na soroconversão, os vírus circulam no organismo dos indivíduos sem a produção imediata de anticorpos específicos. Esse período de tempo na soroconversão varia de acordo com o agente presente e com a metodologia de detecção empregada (SÁEZ-ALQUÉZAR et al., 1996).

As preparações de IgG (2,3,7,8 e 9), nas quais foram encontrados resultados positivos para os anticorpos anti-HTLV I/II por ELISA, acrescentam muitas dúvidas quanto à qualidade da matéria-prima utilizada pelos seus respectivos centros fracionadores, uma vez que, a detecção de anticorpos anti-HTLV é recomendado, mas não é obrigatório. Sabe-se que muitos países não realizam os testes para a detecção de anticorpos nem na triagem sorológica (doadores de sangue), nem no controle da matéria-prima utilizada no fracionamento (CDC, 1989). Dado que os métodos de triagem sorológica para anticorpos HTLV I/II, tais como reações de aglutinação de partículas de látex sensibilizadas ou ainda os testes imunoenzimáticos, apresentam freqüentes resultados falso-positivos, o diagnóstico dessas retroviroses depende da confirmação de sororeatividade através das técnicas por Western Blot ou radioimunoprecipitação (SEGURADO, 1996).

Por outro lado, o teste para determinação do HTLV I/II por PCR, técnica muito mais sensível do que os métodos de ELISA e Western Blot, atualmente, está disponível para uso em laboratórios de pesquisa, mas não nos laboratórios de triagem sorológica, por causa das dificuldades metodológicas inerentes ao método. Ao contrário do que se observa na infecção pelo HIV, não se detectam partículas virais livres de HTLV I/II no plasma de indivíduos infectados, acreditando-se assim que as partículas virais sejam exclusivamente associadas aos linfócitos infectados (SEGURADO, 2000). O diagnóstico molecular de infecção por HTLV I/II baseia-se na pesquisa de seqüências genômicas provirais em células mononucleares periféricas lisadas enzimaticamente. Para tal empregam-se as técnicas de amplificação de segmentos genômicos por PCR. 
Os índices mundiais de prevalência do vírus HTLV I/II são baixos e o método por Western Blot revelou alguns resultados indeterminados (preparações 2, 7, 8 e 9) e, por essa técnica, somente a preparação 3 apresentou resultado positivo para anticorpos IgG anti-HTLV I/II

De acordo com o fabricante do conjunto diagnóstico utilizado, as frações antigênicas que indicam soropositividade para o HTLV I são: reagente para (gag) p19 com ou sem p24 e duas bandas (env) GD21 e rgp46-I; e reagente para o HTLV II (gag) p24 com ou sem p19 e duas bandas (env) GD21 e rgp46-II. Como os indivíduos infectados por qualquer dos tipos de vírus HTLV apresentam anticorpos circulantes que exibem reatividade cruzada ao tipo heterólogo, a identificação de soropositividade, após a realização dos testes confirmatórios, deve ser interpretada como evidência de infecção por HTLV I ou HTLV II (SEGURADO, 1996). Entretanto, diversos estudos revelam que a maioria dos indivíduos soroindeterminados não se mostra infectada pelo HTLV I ou II após a investigação diagnóstica molecular (LIPKA et al., 1991; LAL et al., 1992; CDC, 1993).

Comparando o padrão de anticorpos anti-HTLV encontrado pela técnica de Western Blot, com os resultados das provas diagnósticas moleculares, observa-se que os indivíduos que exibem simultaneamente anticorpos contra os antígenos codificados pelos genes (env) e (gag), quase invariavelmente, se mostram infectados pelo vírus (SEGURADO, 1996).

Dando continuidade à discussão dos nossos resultados, embora todas as preparações de lgG estudadas não tenham revelado a presença do antígeno, o anticorpo anti-HBc é um importante marcador sorológico indireto do vírus B da hepatite. Os testes positivos para o anti-HBc não significam que o indivíduo seja portador do vírus, entretanto, existem alguns relatos na literatura indicando a presença do genoma do HBV em indivíduos, doadores de sangue ou não, que apresentam resultados positivos de anticorpos anti$\mathrm{HBc}$ e AgHBs negativo. A porcentagem desses indivíduos com anti-HBc positivo e portadores do vírus é maior do que os indivíduos com resultado negativo (SÁEZ-ALQUÉZAR et al., 1994; ALTER, 1995). De maneira geral, 
como a detecção de anticorpos anti-HBc não é obrigatória em muitos países, a grande maioria dos centros fracionadores não realizam esse teste nem no controle da matéria-prima nem no produto final.

De modo previsível, encontramos em todas as preparações de lgG resultados positivos para detecção do anticorpo IgG anti-HAV, pois tanto na nossa população como em outras, acima de $90 \%$ dos indivíduos apresentam esse anticorpo circulante.

Classicamente, os anticorpos IgG anti-HAV são detectados logo após o aparecimento do anticorpo IgM anti-HAV, o primeiro marcador da hepatite A. Os títulos aumentam gradualmente durante a evolução da doença, persistindo durante toda a vida e conferindo imunidade contra a infecção pelo HAV. A presença do anticorpo da classe IgM anti-HAV nas preparações 3 e 7 configuram casos de infecções recentes causadas pelo HAV. Em outras palavras, os indivíduos doadores de sangue estiveram em contato recente com o vírus da hepatite $A$ e isto significa, em tese, que as referidas preparações correm o risco de apresentar frações antigênicas infectantes (LEMON, 1994).

Recentemente, seis casos de infecção causada pelo vírus da hepatite A foram diagnosticados nos Estados Unidos, incluindo quatro pacientes que receberam concentrados de fator VIII e dois que receberam infusão de concentrado de fator IX (CHAMBERLAND, 1999).

A detecção de anticorpos IgG anti-T.pallidum e anticorpos anticardiolipina (ou anticorpos não-treponêmicos) nas preparações 1, 2, 3, 7 e 8 pode ser explicada pela qualidade duvidosa da matéria-prima empregada no fracionamento. A presença desses anticorpos, suscitados pelas infecções observadas na sífilis, denota contaminação dos indivíduos com o antígeno que é transmitido não só sexualmente, mas também pela disseminação do uso de drogas (CAMARGO, 1996). Na prática, através da preparação 9, pudemos verificar que, todos os testes realizados para a detecção dos anticorpos contra o T.pallidum e para determinação de anticorpos anticardiolipina com resultados positivos, a origem da matéria-prima coletada não foi confiável. 


\subsubsection{Eficácia dos processos de fracionamento da IgG}

Os vários métodos empregados no fracionamento de proteínas derivadas do plasma, tais como albumina, imunoglobulinas, fatores VIII e IX da coagulação sangüínea, entre outras, estão baseados nos seguintes princípios: 1) diferencial de solubilidade das proteínas, 2) diferencial de interação das proteínas com o meio sólido e 3) diferencial de interação das proteínas por ações físicas.

Os métodos baseados no diferencial de solubilidade mais empregados em escala industrial são: crioprecipitação, precipitação isoelétrica, precipitação de euglobulinas, desalinização com sais neutros ou aminoácidos, precipitação com polímeros neutros (exclusão) (DEUTSH et al., 1946), fracionamento com etanol a frio (COHN, et al. 1946), precipitação com clorofórmio (LIAUTAUD et al., 1974), precipitação com glicina (NEWMAN et al., 1971) e precipitação com polietilenoglicol (PEG) (WICKERHAUSER , 1971).

Porém, nesses métodos de precipitação, a fase de separação sólido do líquido representa uma grande dificuldade operacional, uma vez que, podem ocorrer significativas perdas na concentração final das proteínas. Segundo estudos feitos por ROTHSTEIN et al. (1977), especificamente, na obtenção de albumina pelo método de COHN, registraram-se perdas de até 10\% da proteína na fração IV de precipitação. Também a etapa de centrifugação é considerada um fator limitante, já que o processo de fracionamento precisa ser interrompido para remoção dos precipitados formados (COHN et al., 1950).

Alguns fabricantes não declaram totalmente seus procedimentos, mas pudemos observar, por exemplo, que a preparação proveniente da Índia apresentou baixa concentração de lgG total devido a etapas inadequadas durante o processo de separação do anticorpo.

O método clássico de COHN et al. (1946) permite, simplesmente variando-se as concentrações de etanol, o pH da solução e a temperatura, a obtenção das seguintes frações protéicas: fração I (fator VIII, fibrinogênio, 
fibronectina e componentes do complemento); fração II (IgG, IgA, IgM, fator II, VII, IX, X e globulinas); fração IV-1 ( $\alpha$ - e $\beta$-globulinas, anti-trombina-III, $\alpha 1$ antitripsina, IgM e componentes do complemento); fração IV-4 ( $\alpha$ - e $\beta$ globulinas, transferrina, ceruloplasmina e haptoglobina) e fração $\vee$ (albumina e $\alpha$ - e $\beta$-globulinas). Em 1957, HINK et al. introduziram modificações no método de COHN que permitiram reduzir uma etapa de fracionamento melhorando, assim, o rendimento final. Entretanto, foram as modificações feitas por KISTLER e NITSCHMANN (1962) e SCHNEIDER et al. (1975) que propiciaram etapas de fracionamento mais rápidas e eficientes.

A partir dessas modificações, o método de COHN tem sido largamente utilizado em escala industrial, apresentando algumas importantes vantagens, como: o etanol usado tem baixo custo e pode ser facilmente encontrado no mercado; os processos e os produtos obtidos estão bem especificados; os produtos apresentam grau de pureza acima de 95\%; as tecnologias de produção e de controle de qualidade são amplamente conhecidas (SCHNEIDER et al., 1975).

Porém, o método modificado de COHN também apresenta algumas desvantagens, como: a utilização de reagentes de pureza maximizada; o etanol utilizado precisa ser 100\% removido e essas etapas de remoção encarecem o processo, além de possibilitarem a desnaturação e a contaminação dos produtos finais; a produção precisa ser realizada em áreas físicas sob baixas temperaturas, o que representa um grande inconveniente para a saúde dos operadores; as grandes áreas requeridas na produção e os tanques de processamento precisam ficar sob permanente refrigeração e para finalizar, os processos são descontínuos e manuais, o que propicia a desnaturação das proteínas, por isso mesmo, não é indicado para o fracionamento de IgG para administração intravenosa.

Os métodos de fracionamento baseados no diferencial de interação com o meio sólido, tais como adsorção, cromatografia líquida de troca iônica (FRIESEN et al., 1983; SUOMELA et al., 1983), cromatografia de interação hidrofóbica e de afinidade (HARVEY, 1980), cromatografia líquida de gelpermeação (FRIEDLI e KISTLER, 1972) e separação em membrana neutra 
(ultrafiltração) (FRIEDLI et al., 1976) permitem a obtenção de IgG (iv) e outras proteínas em escala laboratorial, com alto grau de pureza (acima de 96\%) e moléculas com as porções Fab e Fc mais íntegras (JOHNSON et al., 1983). O desenvolvimento de novos produtos, tipo os géis de sílica e os géis sintéticos (Mono Q, Mono P, Mono S - Pharmacia Fine Chemicals), possibilitaram, ainda, a utilização das técnicas cromatográficas em escala intermediária de produção (500 litros de plasma por semana) (HEIDE et al., 1977).

De acordo com a nossa experiência na Fundação Pró-Sangue Hemocentro de São Paulo, utilizando a metodologia desenvolvida por TANAKA e colaboradores (1998) para obtenção de IgG (iv), pudemos verificar que os métodos cromatográficos de troca iônica e de gel-filtração, além de não necessitarem baixas temperaturas de operações, fornecem preparações puras e concentradas (5-7g\%), nas quais as moléculas encontram-se mais íntegras (97-99\% de pureza) (fragmentos Fab e Fc preservados). Outra grande vantagem apontada é que os métodos cromatográficos podem ser automatizados, o que permite um controle mais eficiente sobre as etapas de fracionamento do plasma, evitando-se, assim, perdas excessivas de proteínas.

Entretanto, os métodos por cromatografia apresentam algumas limitações, tais como: as colunas cromatográficas ainda possuem baixas capacidades de processamento (abaixo de 1000 litros de plasma por semana); os géis cromatográficos estão disponíveis somente para poucos centros fracionadores; além disso, os processamentos por cromatografia consomem grande quantidade de água (acima de 2000 litros) com especificação livre de pirogênio, considerada um solvente de alto custo de obtenção.

Nas duas últimas décadas, a utilização do método de $\mathrm{COHN}$ modificado na etapa inicial de separação, associado aos métodos cromatográficos nas etapas de purificação, tem permitido a obtenção imunoglobulinas em larga escala, para uso humano por via intravenosa, 
contornando-se as desvantagens inerentes de cada método em separado (SUOMELA, 1983).

Particularmente, nossa experiência no fracionamento de IgG nos permitiu verificar também que a última etapa de produção, a liofilização, além de ter um alto custo, pode ser uma fonte desnecessária de contaminação. A preparação final de IgG pode ser armazenada na forma de solução líquida sem prejuízo de sua qualidade. Os testes de estabilidade e prazo de validade, recomendados pela Portaria MS n².419 (17/12/1996) e realizados segundo a Farmacopéia Européia (1997), mostraram que as preparações de IgG, na forma de solução líquida, podem ser armazenadas por 24 meses sob temperatura de geladeira $\left(2\right.$ a $\left.8{ }^{\circ} \mathrm{C}\right)$.

\subsubsection{Eliminação de agentes patogênicos}

Nosso estudo comparativo mostrou significativos resultados positivos ou indeterminados na detecção de anticorpos para vários agentes patogênicos, tais como HTLV I/II, HAV, HBV, HCV e T.pallidum, em algumas das preparações de IgG estudadas. Acreditamos que a presença desses anticorpos, ou até mesmo a possível presença dos próprios antígenos, pode ser causada pela utilização de misturas de plasma humano não devidamente testado para esses agentes.

Em 1994, nos Estados Unidos, uma grande quantidade de casos de hepatite $\mathrm{C}$ foi verificada e tudo indicava estar associada ao uso de preparações de imunoglobulinas para uso intravenoso. O fabricante foi acionado e, depois de vários estudos conjuntos, verificou-se que o processo de fracionamento pelo método clássico de Cohn, com uma etapa final de purificação por cromatografia, não incluía etapas de inativação viral, foi o responsável pela contaminação de mais de duzentos pacientes nos Estados Unidos, Japão e Europa (CDC, 1994). Assim, os riscos de contaminações serão bastante minimizados, ou seja, o uso do sangue e produtos derivados (albumina, IgG e fatores de coagulação) será altamente seguro quando: os procedimentos de seleção dos doadores forem ainda mais rigorosos; surgirem testes laboratoriais mais sensíveis e específicos para avaliação do 
sangue e produtos derivados; e quando aprimorarem-se ainda mais os processos de purificação e inativação viral.

Na Fundação Pró-Sangue Hemocentro de São Paulo, a albumina fracionada por métodos cromatográficos é rotineiramente inativada por processo de pasteurização $\left(60^{\circ} \mathrm{C}\right.$ por 10horas). Por outro lado, as preparações de IgG são submetidas à inativação segundo o método descrito por HOROWITZ et al. (1985), no qual se utiliza, inicialmente, o método do solvente/detergente com tri(n-butil)fosfato $1 \%$ / Triton X-100 1\%, a $35^{\circ} \mathrm{C}$ por 10 horas. A mistura solvente/detergente é removida da solução de lgG por cromatografia de troca iônica. Numa segunda etapa, à solução de lgG é adicionada pepsina $0,1 \mathrm{mg} / \mathrm{g}$ de proteína em $\mathrm{pH}$ 4. A associação do dois processos tem-se mostrado eficaz para inativar os chamados vírus envelopados (envelope lipoprotéico), tais como HIV, HBV e HCV e os chamados vírus não-envelopados (envelope glicoprotéico), tais como HAV e Parvovírus B19.

A inativação e/ou remoção de vários agentes patogênicos (vírus, bactérias e outros microorganismos) do sangue e produtos derivados, fundamentalmente, se faz necessária por causa: da existência da janela imunológica, dos possíveis erros laboratoriais e também por causa da presença de muitos vírus ainda desconhecidos ou não reconhecidos durante os testes de avaliação sorológica. A inativação e/ou remoção viral requer condições para desnaturar somente a estrutura molecular desses agentes, preservando todas as porções das moléculas de anticorpos responsáveis pelas atividades biológicas e propriedades imunogênicas (Fc).

Os processos de eliminação viral estão divididos em duas classes: 1) os métodos de inativação, tais como físicos (calor, irradiação e desnaturação), químicos (solvente/detergente, fotoquímico) e imunológicos e 2) os métodos para remoção, tais como filtração, adsorção (específica e não específica) e partição (cromatografia de afinidade) (UEMURA et al., 1994).

A despeito de todos os critérios de triagem clínica e sorológica e, dos grandes avanços conseguidos nas tecnologias de eliminação viral, todos esses métodos de eliminação de microorganismos patogênicos apresentam 
vantagens e desvantagens que merecem uma avaliação individual, pois, muito freqüentemente, encontramos descritos na literatura casos de transmissão de vírus pelo sangue e produtos derivados utilizados em transfusões ou em terapias de reposição.

Assim, entre os métodos físicos mais empregados encontramos a inativação viral por calor seco $\left(80-82^{\circ} \mathrm{C}\right.$ por 72 horas), que apresenta algumas vantagens, tais como inativação de uma ampla variedade de vírus, é de simples execução e quando realizado no produto final, eliminam-se as recontaminações. Porém, esse processo apresenta algumas desvantagens: para proteger as proteínas mais sensíveis ao calor (termolábeis), cada produto fracionado requer uma formulação específica (BRESSE et al., 1996); do mesmo modo, alguns vírus críticos como o HIV e o HCV, em razão dos estabilizadores adicionados, não são inativados.

Ainda dentro dos métodos físicos, podemos citar a pasteurização na qual, geralmente, a solução é aquecida a $60^{\circ} \mathrm{C}$ por 10 horas. Esse processo contribui para inativar uma larga variedade de microorganismos, é de fácil execução e validação, porém, também requer a adição de substâncias estabilizadoras durante o processo de aquecimento para que não haja desnaturação dos produtos, exemplo típico das imunoglobulinas. Além disso, pelo processo de pasteurização, os chamados vírus críticos (HIV, HBV, HCV e HTLV) não são totalmente inativados e são grandes as chances de recontaminação do produto final (CURLING, 1983).

O processo de aquecimento do produto liofilizado, no qual as preparações de IgG ou de fatores da coagulação são submetidas ao vácuo e eliminação gradual da umidade pelo uso de diferentes níveis de temperatura, auxilia principalmente na estabilidade do produto. Porém, uma grande desvantagem do método reside no fato de que muitos detalhes técnicos do processo não são, ainda, totalmente conhecidos e controlados (DEJANOV et al., 1983).

Outro processo de inativação viral empregado utiliza uma associação entre a $\beta$-propiolactona e luz ultravioleta (UV) em comprimento de onda de 254nm. Esse processo promove a inativação tanto pela ação do reagente 
químico como pela incidência da energia luminosa UV (DICHTELMÜLLER e STEPHAN, 1983). Porém, o método é bastante discutível e apresenta algumas desvantagens que devem ser consideradas, pois: o reagente utilizado ( $\beta$-propiolactona) é potencialmente tóxico e precisa ser rigorosamente removido ao final do processo.

Outro processo de inativação viral, bastante utilizado durante o fracionamento de imunoglobulinas, emprega o tratamento das soluções de IgG com pepsina em $\mathrm{pH} 4$ a $37^{\circ} \mathrm{C}$ por 10 a 12 horas. O método mostra resultados eficientes na inativação dos vírus envelopados, mas não para os vírus não-envelopados. Ao final das etapas de inativação, a pepsina deve ser totalmente retirada da solução (KEMPF et al., 1991).

O método de nanofiltração está baseado na remoção dos vírus através de membranas com porosidade de 15nm ou DV20 (15 a 30nm ). O processo de nanofiltração evita o uso de produtos químicos tóxicos e é de fácil execução, contudo, o processo não inativa os vírus, somente os remove. Além disso, a cada nova etapa de remoção, todos os filtros utilizados no processo precisam ser validados independentemente.

O método de inativação por cromatografia de afinidade baseia-se na adsorção específica tanto dos vírus quanto do produto fracionado. Esse método possui alta seletividade e, simultaneamente, purifica as proteínas e remove os vírus. Entretanto, algumas desvantagens podem ser apontadas, pois o método purifica somente algumas proteínas, tais como imunoglobulinas e fatores de coagulação. Esse método também não inativa os vírus, somente os remove. O processo não é reprodutível em larga escala de produção e existem chances de recontaminação dos produtos, fato também relatado por YAP (1996).

Atualmente, o tratamento das soluções de proteínas pelo método do solvente/detergente tem sido largamente utilizado e sua principal característica é a inativação dos chamados vírus lípide-envelopados. 0 método utiliza uma combinação de tri(n-butil)fosfato e Tween 80 ou Triton X100. Esse processo tem alta margem de segurança, está totalmente validado, é de fácil implantação e execução, principalmente em larga escala 
de produção, nenhum caso de transmissão dos vírus HIV, HBV ou HCV foi confirmado e, finalmente, relatam-se altos índices de recuperação dos produtos após a etapa de remoção da mistura solvente/detergente (HOROWITZ et al., 1993). Contudo, o método não se aplica com a mesma eficiência à inativação de vírus não-envelopados (HAV e Parvovírus B19), além disso, também pode favorecer as recontaminações dos produtos finais (HOROWITZ et al., 1998).

\subsubsection{Espectro de atividades anticórpicas específicas}

Um dos objetivos desse estudo foi a realização de algumas determinações para detecção de anticorpos específicos. Altos títulos de anticorpos presentes na matéria-prima são muito úteis para o fracionamento de imunoglobulinas com atividades anticórpicas específicas. Verificamos isso através das preparações de IgG que mostraram resultados positivos na detecção de anticorpos anti-HBs. As preparações de IgG com altos títulos de atividade anticórpica anti-HBs podem ser usadas, entre outras aplicações clínicas, em pacientes submetidos a transplantes de fígado, ou ainda no tratamento das infecções graves causadas pelo vírus da hepatite $B$, proporcionando grandes benefícios terapêuticos.

Nossos resultados mostraram a eficácia das preparações de IgG quanto às atividades anticórpicas contra alguns agentes como anti-rubéola, anti-citomegalovírus, anti-estreptolisina $\mathrm{O}$, anti-herpes simples e antiToxoplasma gondii.

Em uma imunoglobulina íntegra, as três regiões hipervariáveis, também chamadas de regiões determinantes de complementariedade (CDRs), de uma cadeia leve e as três regiões hipervariáveis de uma cadeia pesada podem ocupar conjuntamente um espaço tridimensional para formar uma superfície de ligação para o antígeno. Nas moléculas de lgG, a região mais suscetível à desnaturação é a dobradiça localizada entre C $\gamma 1$ e C $\gamma 2$ da cadeia pesada. Em resumo, as regiões $\mathrm{V}$ das cadeias pesadas e leves (fragmentos $\mathrm{Fab}$ ) respondem pelo reconhecimento do antígeno e a região das cadeias pesadas (fragmento Fc) é responsável pelo início das funções 
efetoras (ABBAS et al., 2000).

As funções efetoras dos anticorpos são desencadeadas a partir da ligação ao antígeno e são mediadas por seus fragmentos Fc. Uma vez ligados, os anticorpos podem impedir estereoquimicamente a interação do antígeno com receptores específicos da superfície celular, neutralizando, assim, processos tóxicos ou infecciosos desde que não sofram quaisquer alterações ou danos nas suas conformações moleculares (WORDELL, 1991). 
6. CONCLUSÕES 
Nas preparações 1, 5 e 8 a concentração protéica de lgG e a distribuição das subclasses IgG1, IgG2, IgG3 e IgG4 estão fora das faixas de referência encontradas na literatura.

- Todas as preparações de IgG apresentam atividade de anticorpos específicos para alguns microorganismos que muito freqüentemente acometem a população, tais como os vírus da hepatite $\mathrm{A}$ e $\mathrm{B}$, do herpes simples (1 e 2), da rubéola, citomegalovírus; para a bactéria Streptococcos pyogenes $\beta$-hemolítico do grupo A (ASLO) e para o parasita Toxoplasma gondii.

> Nas preparações 3, 7, 8 e 9 de IgG, a qualidade do plasma utilizado no fracionamento é inadequada em função das reações positivas para anticorpos contra alguns agentes infecciosos, tais como HTLV I/II, HCV e Treponema pallidum. As preparações 3 e 7 apresentam positividade para anticorpos IgM contra o vírus da hepatite $\mathrm{A}$ e, além desses marcadores diretos, a maioria das preparações apresentam positividade para o anti$\mathrm{HBc}$, marcador indireto da hepatite $\mathrm{B}$.

Sobretudo, de acordo com os resultados obtidos em nosso estudo, concluímos que é de fundamental importância a elaboração e implantação de um programa nacional para se avaliar adequadamente a garantia da qualidade, não só de todas as preparações de imunoglobulinas importadas que entram no país, bem como de todos os outros produtos derivados do sangue humano. 
7. ANEXOS 


\section{ANEXO A. Descrição das Preparações de Imunoglobulina G}

1. Imunoglobulina G humana, liófilo injetável, produto pasteurizado apresentado em embalagem contendo: um frasco com 2500 mg de IgG para infusão (iv) + diluente de $50 \mathrm{~mL}$ + equipos de transferência e de infusão intravenosa. O produto passa por um processo de termoinativação viral em fase líquida (pasteurização), que consiste do aquecimento em solução aquosa a $60^{\circ} \mathrm{C}$ por 10 horas.

2. Produto pasteurizado e liofilizado apresentado em embalagem contendo: um frasco com 5,0 g de IgG humana iv + um frasco com $100 \mathrm{~mL}$ de água estéril para reconstituição e dispositivos de transferência e infusão.

3. Produto líquido, vírus inativado, apresentado em embalagem contendo: um frasco com 2,5 g de IgG humana em $50 \mathrm{~mL}$ de solução. O produto passa por um processo de inativação viral utilizando a técnica de solvente/ detergente.

4. Imunoglobulina $\mathrm{G}$ humana liofilizada iv, produto apresentado em embalagem contendo: $3 \mathrm{~g}$ de proteína + $100 \mathrm{~mL}$ de diluente + equipamentos de transferência e sistema de infusão. O produto é obtido, por fracionamento do plasma, de acordo com o processo de KistlerNitshmann (1962). A segurança do método de fabricação foi estabelecida por um estudo de inativação de vírus, que mostrou ser a etapa da pepsina / pH 4 capaz de inativar os vírus que possam estar presentes no produto.

5. Imunoglobulina $G$ humana iv purificada e intacta, liofilizada, apresentada em embalagem contendo: um frasco-ampola com 2500 mg + um frascoampola com $50 \mathrm{~mL}$ de água injetável + equipo para infusão iv.

6. Imunoglobulina $G$ humana liofilizada, solução injetável intravenosa, apresentada em embalagem contendo: um frasco com 2,5 g de proteína + um frasco com $50 \mathrm{~mL}$ de água destilada. Sua fabricação combina separação da proteína por etanol a frio com uma fase de purificação especial. 
7. Imunoglobulina $\mathrm{G}$ humana, solução injetável intravenosa, apresentada em embalagem contendo : um frasco de $10 \mathrm{~mL}$ com 0,5 g de proteína. $\mathrm{O}$ produto é purificado por cromatografia. O produto final é inativado pela técnica do solvente/detergente, patente requerida pelo New York Blood Center (NYBC), U.S.A.

8. Imunoglobulina $G$ humana liofilizada, para administração iv, produto apresentado em embalagem contendo: um frasco de $6 \mathrm{~g}$ de proteína para reconstituição com $200 \mathrm{~mL}$ de cloreto de sódio injetável B.P. 0,9\% $\mathrm{m} / \mathrm{v}$.

9. Imunoglobulina $G$ humana, solução injetável intravenosa, apresentada em embalagem contendo: um frasco com 2,5 g de proteína em $50 \mathrm{~mL}$ de solução estéril. O produto é fabricado por fracionamento de uma mistura plasmática com etanol a frio , filtrada e ultracentrifugada.

10. Imunoglobulina $G$ humana liofilizada, intravenosa, produto apresentado em embalagem contendo: um frasco com 2,5 g + um frasco de $50 \mathrm{~mL}$ de água estéril (injetável) USP + sistema de transferência para reconstituição doliofilizado. 


\section{ANEXO B. Critérios Oficiais para Doação de Sangue - Portaria MS n`1376 de 19 de novembro de 1993}

- Estar em boas condições de saúde;

- Ter entre 18 e 60 anos;

- Ter peso igual ou superior a 50 quilos;

- Estar alimentado;

- Evitar alimentação pesada antes da doação ; aguardar três horas após o almoço e uma hora após o lanche;

- Estar afebril;

- Não deve ser portador de doenças infecto-contagiosas transmitidas pelo sangue;

- Intervalo entre as doações: 60 dias para os homens e 90 dias para as mulheres, sendo permitida no máximo quatro doações por ano;

- Níveis de hemoglobina: mulheres igual ou maior a $12 \mathrm{~g} / \mathrm{dL}$ e homens igual ou maior a $13 \mathrm{~g} / \mathrm{dL}$;

- Pressão arterial: diastólica até $100 \mathrm{~mm} \mathrm{Hg}$ e sistólica até $180 \mathrm{~mm} \mathrm{Hg}$;

- Freqüência cardíaca entre 60 a 110 batimentos por minuto;

- Não estar utilizando os seguintes medicamentos: antibióticos, quimioterápicos, corticosteróides, anticoagualntes orais, agentes hipoglicemiantes, antipsicóticos;

- Não ter recebido hormônio de crescimento de origem humana em qualquer fase da vida;

- Não estar grávida ou em estado puerperal, até três meses após o parto;

- Exclusão de abortamento até 12 semanas;

- 10 anos de exclusão para candidatos com história de transfusão de sangue, componentes ou derivados do plasma humano;

- Não ter recebido vacina de vírus vivo atenuado até duas semanas antes da doação;

- Exclusão por 10 anos de candidatos que receberam vacina para hepatite B derivada do plasma humano; 
- Exclusão por quatro semanas de candidatos que receberam vacina de sarampo e BCG;

- Exclusão por um ano de candidatos que receberam vacina anti-rábica;

- Exclusão por 10 anos de candidatos que receberam imunização passiva;

- Excluir ,definitivamente, candidatos que apresentem ou apresentaram em alguma fase da vida as seguintes doenças: Chagas, AIDS, KreutzfeldJacob, HTLV-I/II, Malária;

- Excluir, definitivamente, parceiros de portadores do vírus da AIDS;

- Excluir por seis meses parceiros de portadores de hepatite B;

- Excluir, definitivamente, candidatos com história de hepatite viral após 10 anos de idade;

- Excluir, definitivamente, candidatos que apresentarem testes positivos para HBsAg e/ou positivo para HCV e/ou níveis de ALT maior que duas vezes o valor normal em mais de uma ocasião e/ou positivo para antiHBc em mais de uma ocasião;

- Excluir candidatos provenientes de regiões endêmicas de Malária por seis meses;

- Só serão aceitos candidatos com história de sífilis, comprovadamente curados, com exames sorológicos negativos;

- Exclusão de alcoolismo agudo ou crônico;

- Exclusão definitiva de usuários de drogas intravenosas que possam causar dependência;

- Não são aceitos candidatos com história de perda de peso superior a $10 \%$ do peso corporal em três meses sem causa aparente;

- Não são aceitos os indivíduos que tiveram doenças graves nos últimos 30 dias;

- Recusa temporária de candidatos que estiverem apresentando estado gripal;

- Exclusão temporária por 72 horas de candidatos que se submeteram à extração ou manipulação dentária, por três meses a cirurgias de pequeno porte, por seis meses a cirurgias de grande porte;

- Exclusão temporária de candidatos com urticária, asma e febre do feno; 
- Recusa temporária de candidatos por tatuagem e acupuntura por doze meses;

- Recusa temporária de candidatos por lesão de pele no local da punção. 
8. REFERÊNCIAS BIBLIOGRÁFICAS 
ABBAS, A.K., LICHTMAN, A.H., POBER, J.S. Celular and molecular immunology. 2.ed. Philadelphia: W.B. Saunders, 1994. 457p.

ABBAS, A.K., LICHTMAN, A.H., POBER, J.S. Imunologia celular e molecular. 3.ed. Rio de Janeiro: Revinter, 2000. 486p.

ALTER, M.J. Residual risk of transfusion-associated hepatitis. NIH consensus development conference, infectious disease testing for blood transfusions, 1995, p.23-27. (Abstract). Apud: DODD, R.Y. Infectious risk of plasma donations: relationship to safety of intravenous immune globulins. Clin. Exp. Immunol., Oxford, v.104, suppl. 1, p.31-34, 1996.

AMMANN, A.J. Antibody (B cell) immunodeficiency disorders. In: STITES, D.P., TERR, A.I., eds. Basic and clinical immunology. 8.ed. Norwalk: Appleton \& Lange, 1994. p.266-278.

ANNEREN, G., MAGNUSSON, C.G., LILJA, G., NORDVALL, S.L. Abnormal serum IgG subclass pattern in children with Down's syndrome. Arch. Dis. Child., London, v.67, n.5, p.628-631, 1992.

AUCOUTURIER, P., BREMARD-OURY, C., GRISCELlI, C., BERTHIER, M., PREUD'HOMME, J.L. Serum IgG subclass deficiency in ataxia telangiectasia. Clin. Exp. Immunol., Oxford, v.68, n.2, p.392-396, 1987.

BARANDUN, S., KISTLER, P., JEUNET, F., ISLIKER, H. Intravenous administration of human $\gamma$-globulin. Vox Sang., Basel, v.7, p.157-174, 1962.

De acordo com a Norma NBR6023/90 preconizada pela Associação Brasileira de Normas Técnicas (ABNT). As abreviaturas dos periódicos seguem o Chemical Abstracts Service Source Index (CASSI) 1999 [Cd-rom]. 
BARTMANN, P., GROSCH-WORNER, I., WAHN, V., BELOHRADSKY, B.H. IgG2 deficiency in children with human immunodeficiency virus infection. Eur. J. Pediatr., Berlin, v.118, n.1, p.82-86, 1991.

BASSION, S. Immunological reactions. In: KAPLAN, L.A., PESCE, A.J., eds. Clinical chemistry: theory, analysis and correlation. 2.ed. St. Louis: Mosby, 1989. p.153-164.

BEARD, L.J., FERRANTE, A. IgG replacement therapy in IgG subclass deficient children. Monogr. Allergy, Basel, v.23, p.194-203, 1988.

BENTUR, L., NISBET-BROWN, E., LEVISON, H., ROIFMAN, C.M. Lung disease associated with IgG subclass deficiency in chronic mucocutaneous candidiasis. J. Pediatr., St. Louis, v.118, n.1, p.82-86, 1991.

BERGGLÖF, H.H., ERIKSSON, S., SUOMELA, H., CURLING, J.M. Albumin from human plasma: preparation and in vitro properties. In: CURLING, J.M., ed. Separation of plasma proteins. Uppsala: Pharmacia Fine Chemicals $A B, 1983$. p.51-58.

BERKEL, A.L. Studies of IgG subclasses in ataxia-telangiectasia patients. Monogr. Allergy, Basel, v.20, p.100-105, 1986.

BERKMAN, S.A., LEE, M.L., GALE, R.P. Clinical uses of intravenous immunoglobulins. Ann. Intern. Med., Philadelphia, v.112, p.278-292, 1990.

BERNATOWSKA-MATUSZKIEWICZ, E., PAC, M., SKOPCYNSKA, H., PUM, M., EIBIL, M.M. Clinical efficacy of intravenous immunoglobulin in patients with severe inflammatory chest disease and IgG3 subclass deficiency. Clin. Exp. Immunol., Oxford, v.85, n.2, p.193-197, 1991.

BJORKANDER, J., BENGTSSON, U., OXELIUS, V.A., HANSON, L.A. Symptoms in patients with lowered levels of IgG subclasses, with or 
without IgA deficiency and effects of immunoglobulin propylaxis. Monogr. Allergy., Basel, v.20, p.157-163, 1986.

BORRADORI, L., BORN, B., DESCOEUDRES, C., SKVARIL, F., MORELL, A. Serum immunoglobulin levels and natural antibodies to haemophilus influenzae in hemodialysis patients: evidence for IgG subclass imbalances. Nephron, Basel, v.56, n.1, p.35-39, 1990.

BRASIL. Ministério da Saúde. Portaria n. 1376 de 19 de novembro de 1993. Dispõe sobre os Critérios Oficiais para Doação de Sangue. Diário Oficial da União, Brasília, 02 dez. 1993. Seção 1, p.18.405.

BRASIL. Ministério da Saúde. Portaria n. 2.419 de 17 de dezembro de 1996. Dispõe sobre Controle de Qualidade de Medicamentos Hemoderivados. Diário Oficial da União, Brasília, 19 dez. 1996. Seção 1, p.27.676.

BRESEE, J.S., MAST, E.E., COLEMAN, P.J., BARON, M.J., SCHONBERGER, L.B., ALTER, M.J., JONAS, M.M., YU, M.W., RENZI, P.M., SCHNEIDER, L.C. Hepatitis C virus infection associated with administration of intravenous immune globulin. JAMA, J. Am. Med. Assoc., Chicago, v.276, p.1563-1567, 1996.

BUSSEL, J.B. Fc receptor blockade and immune thrombocytopenic purpura. Semin. Haematol., v.37, p.261-266, 2000.

BUSSEL, J.B., HILGARTNER, M.W. The use and mechanism of action of intravenous immunoglobulin in the treatment of immune haematologic disease (Annotation). Br. J. Haematol., Oxford, v.56, p.1-7, 1984.

CALICH, V.L.G. Imuneglobulinas. In: CALICH, V.L.G., VAZ, C.A.C., eds. Imunologia básica. São Paulo: Artes Médicas, 1988. p.65-103. p.127132.

CAMARGO, M.E. Sífilis. In: FERREIRA, A.W., ÁVILA, S.L.M., eds. Diagnóstico laboratorial. Rio de Janeiro: Guanabara Koogan, 1996. 
CANAVAGGIO, M., LECKIE, G., ALLAIN, J.P., STEAFFENS, J.W., LAURIAN, Y., BRETTLER, D., LEE, $\mathrm{H}$. The prevalence of antibody to HTLV 1 e 2 in United States plasma donors and United States and French hemophiliacs. Transfusion, Bethesda, v.30, p.780-782, 1990.

CARDOSO, M.S., KOERNER, K., EPPLE, S., KUBANEK, B. Safety of blood products derived from pools: the positive impact of anti-HCV. Screening on the quality of such products. Vox Sang, Basel, v.71, p.184-186, 1996.

CARR-SMITH, H.D., OVERTON, J., BRADWELL, A.R. IgG subclass value assignment to the protein reference preparation CRM470. Clin. Chem., Washington, v.43, n.56, p.238-241, 1997.

CENTERS FOR DISEASE CONTROL, U.S.P.H.S. WORKING GROUP. Guidelines for couseling persons infected with human T-lymphotropic virus type I (HTLV I) and type (HTLV II). Ann. Intern. Med., Philadelphia, v.118, p.448-454, 1993.

CENTERS FOR DISEASE CONTROL. Licensure of screening tests for antibody to human T-lymphotropic virus type I. JAMA, J. Am. Med. Assoc., Chicago, v.261, p.513, 518, 520, 525, 1989.

CENTERS FOR DISEASE CONTROL. Outbreak of hepatitis C associated with intravenous immunoglobulin administration - United States, october 1993 - june 1994: leads from MMWR. JAMA, J. Am. Med. Assoc., Chicago, v.272, n.6, p.424-425, 1994.

CHAMBERLAND, M.E. Surveillance for bloodborne infections. Thromb. Haemostasis, Stuttgart, v.82, n.2, p.494-499, 1999.

CHAMONE, D.A.F. Eficácia terapêutica de preparações de IgG através da contagem de plaquetas. São Paulo, 2001. [Comunicação Pessoal].

CHANDRA, S., BRUMMELHUIS, H.G.J. Prothrombin complex concentrates for clinical use. Vox Sang., Basel, v.41, p.257-273, 1981. 
COHN, E.J., STRONG, L.E., HUGHES Jr., W.L., MULFORD, D.J., ASHWORTH, J.N., MELIN, M., TAYLOR, H.L. Preparation and properties of serum plasma proteins: a system for the separation into fraction of the protein and lipoprotein components of biological tissues and fluids. $\mathbf{J}$. Am. Chem. Soc., Columbus, v.68, p.459-475, 1946.

COHN, E.J., GURD, F.R.N., SURGENOR, D.M., BARNES, B.A., BROWN, R.K. A system for the separation of the components of human blood: qualitative procedure for the separation of the protein components of human plasma. J. Am. Chem. Soc., Columbus, v.72, p.465-474, 1950.

COOMBS, R.R.A., MOURANT, A.E., RACE, R.R. A new test for the detection of weak and "incomplete" Rh agglutinins. Br. J. Exp. Pathol., Oxford, v.26, p.255-259, 1945.

COOPER, M.D., LAWTON, A.R. Primary immune deficiency diseases. In: ISSELBACHER, K.J., ed. Harrison's principles of internal medicine. 13.ed. New York: McGraw-Hill, 1994. p.1559-1566.

CORTONA, L., AVANZINI, M.A., MARTINETTI, M., LORINI, R. Transient IgG subclass deficienies in newly diagnosed diabetic children. Eur. J. Pediatr., Berlin, v.151, n.3, p.179-182, 1992.

COTMORE, S.F. Characterization and molecular cloning of a human parvovirus genome. Science, Washington, v.226, p.1161-1165, 1984.

CURLING, J.M. Current practice and future possibilities in plasma protein fractionation. In: CURLING, J.M., ed. Separation of plasma proteins. Uppsala: Pharmacia Fine Chemicals AB, 1983. p.5-33.

DEJANOV, I., IVANOVSKI, D., JAMOVSKI, O., DAMEVSKA, J., NEDELKOSKI, J., TOPLICANEC, N. A large scale chromatographic procedure for the purification of human plasma immunoglobulin $G$ for intravenous infusion. In: CURLING, J.M.,ed. Separation of plasma proteins. Uppsala: Pharmacia Fine Chemicals AB, 1983. p.141-148. 
DEUTSH, H.F., GOSTINGS, L.J., ALBERTY, R.A., WILLIAMS, J.W. Recovery of gamma-globulin from human blood protein mixtures. J. Biol. Chem., Birmingham, v.164, p.109-115, 1946.

DICHTELMÜLLER, H., STEPHAN, W. Efficacy of different i.v. immunoglobulins in mouse protection test. In: CURLING, J.M., ed. Separation of plasma proteins. Uppsala: Pharmacia Fine Chemicals $A B, 1983$. p.149-156.

DODD, L.G., McBRIDE, H., GITNICK, G.L., HOWANITZ, P.J., RODGERSON, D.O. Prevalence of non-A, non-B hepatitis/hepatitis C virus antibody in human immunoglobulins. Am. J. Clin. Pathol., Chicago, v.97, p.108-113, 1992.

DODD, R.Y. Infectious risk of plasma donations: relationship to safety of intravenous immune globulins. Clin. Exp. Immunol., Oxford, v.104, suppl. 1, p.31-34, 1996.

DROHAN, W.N., CERVENAKOVA, L. Safety of blood products: are transmissible spongiform encephalopathies (prion diseases) a risk? Thromb. Haemostasis, Stuttgart, v.82, n.2, p.486-493, 1999.

DURIGON, E.L., ERDMAN, D.D., GARY, G.W., PALLANSCH, M.A., TOROK, T.T., ANDERSON, L.J. Multiple primer pairs for polymerase chain reaction (PCR) amplification of human parvovirus B19 ADN. J. Virol. Methods, Amsterdam, v.44, p.155-165, 1993.

DUSE, M., TIBERTI, S., PlebANI, A., AVANZINI, M.A., GARDENGHI, M., MENEGATI, E., MONAFO, V., UGAZIO, A.G. IgG2 deficiency and intractable epilepsy of childhood. Monogr. Allergy, Basel, v.20, p.128134, 1986.

ECHEVARRIA, J.M., LEÓN, P., LÓPEZ, J.A., MADURGA, M., SALMERÓN, F., YAP, P.L., DAUB, J., SIMMONDS, P. Laboratory diagnosis and molecular epidemiology of an outbreak of hepatitis $C$ virus infection 
among recipients of human intravenous immunoglobulin in Spain. Transfusion, Bethesda, v.36, p.725-730, 1996.

ELEFANT, G.R. Estreptococias. In: FERREIRA, A.W., ÁVILA, S.L.M., eds. Diagnóstico laboratorial. Rio de Janeiro: Guanabara Koogan, 1996. p.93-100.

ENGVALL, E., PERLMANN, P. Enzyme linked immunoabsorbent assay, ELISA III. J. Immunol., Bethesda, v.109, p.129-135, 1972.

EUROPEAN Pharmacopoeia. 3.ed. Strasbourg: Council of Europe, 1997. $1799 p$.

FERNANDES, P.M., LUNDBLAD, J.L. Preparation of a stable intravenous gama-globulin: process design and scale-up. Vox Sang., Basel, v.39, p.101-112, 1980.

FRIESEN, A.D., BOWMAN, J.M., BEES, W.C.H. Column ion exchange chromatographic production of human immuneglobulins and albumin. In: CURLING, J.M., ed. Separation of plasma proteins. Uppsala: Pharmacia Fine Chemicals AB, 1983. p.117-126.

GILHUS, N.E., LEA, T. IgG subclasses in epileptic patients treated with phenyntoin. J. Neurol., Berlin, v.236, n.3, p.149-152, 1989.

GOODMAN, J.W. Immunoglobulin structure and function. In: STITES, D.P., TERR, A.I., eds. Basic and clinical immunology. 7.ed. Norwalk: Appleton \& Lange, 1991. p.109-121.

GOODMAN, J.W. The Immnune response. In: STITES, D.P., TERR. A.I., eds. Basic and clinical immunology. 8.ed. Norwalk: Appleton \& Lange, 1994a. p.40-49.

GOODMAN, J.W., PARSLOW, T.G. Immunoglobulin proteins. In: STITES, D.P., TERR, A.I., eds. Basic and clinical immunology. 8.ed. Norwalk: Appleton \& Lange, 1994b. p.66-79. 
GORNALL, A.G., BARDAWIILL, C.J., DAVID, M.M.J. Determination of serum protein by means of biuret reaction. J. Biol. Chem., Birmingham, v.177, p.751-766, 1949.

GRABAR, P., WILLIAMS Jr., C.A. Méthode permettant L' étude conjuguée des propriétés électrophorétiques et immnuochimique d' un mélange de protéines: application au sérum sanguin. Biochim. Biophys. Acta, Amsterdam, v.10, p.193-194, 1953.

GREY, H.M., KUNKEL, H.G. H-chain subgroups of myeloma proteins and normal 7S $\gamma$-globulin. J. Exp. Med., New York, v.120, p.253-262, 1964.

HAMILTON, R.G. Human IgG subclass measurements in the clinical laboratory. Clin. Chem., Washington, v.33, p.1707-1725, 1987.

HAMMARSTROM, L., PERSSON, M.A., SMITH, C.L. Immunoglobulin subclass distribution of human anti-carbohydrate antibodies: aberrant pattern in IgA-deficient donors. Immunology, Oxford, v.54, n.4, p.821826, 1985.

HARRIS, A., ROSENBERG, A.A., RIEDEL, L.M. A microflocculation test for syphilis using cardiolipin antigen: preliminary report. J. Vem. Dis. Inform., v.27, p.169-174, 1946.

HÄSSIG, A. Intravenous immunoglobulins: pharmacological aspects and therapeutic use. Vox Sang., Basel, v.51, p.10-17, 1986.

HAWKES, R., NIDAY, E., GORDON, J. A dot-immunobinding assay for monoclonal and other antibodies. Anal. Biochem., Orlando, v.119, n.1, p.142-147, 1982.

HAY, E.M., FREEMONT, A.J., KAY, R.A., BERNSTEIN, R.M., HOLT, P.J., PUMPHREY, R.S. Selective polyclonal increase of immunoglobulin G1 subclass: a link with Sjogren's syndrome. Ann. Rheum. Dis., London, v.49, n.6, p.373-377, 1990. 
HEIDE, K., HAUPT, H., SCHWICK, H.G. In: PUTNAM, F.W., ed. Plasma protein fractionation: the plasma proteins. New York: Academic Press, 1977. v.3, p.545-597.

HEINER, D.C., LEE, S.I., SHORT, J.A. IgG4 subclass deficiency syndromes. Monogr. Allergy, Basel, v.20, p.149-156, 1986.

HEINER, D.C. IgG4 immunodeficiency. N. Engl. Reg. Allergy Proc., Boston, v.9, n.1, p.43-50, 1988.

HINK, J.H., HILDAGO, J., SEEBERG, V.P., JOHNSON, F.F. Preparation and properties of a heat-treated human plasma protein fraction. Vox Sang., Basel, v.2, p.174-186, 1957.

HOROWITZ, B., LAZO, A., GROSSBERG, H., PAGE, G., LIPPIN, A., SWAN, G. Virus inactivation by solvent/detergent treatment and the manufacture of SD-plasma. Vox-Sang., Basel, v.74, suppl. 1, p.203-206, 1998.

HOROWITZ, B., PRINCE, A.M., HOROWITZ, M.S., WATKLEVICZ, C. Viral safety of solvent-detergent treated blood products. Dev. Biol. Stand. Basel, v.81, p.129-147, 1993.

HOROWITZ, B., WIEB, M.E., LIPPIN, A., STRYKER, H. Inactivation of viruses in labile blood derivatives. Transfusion, Bethesda, v.25, p.516522, 1985.

INSLER, M.S., GORDON, R.A. Absolute IgG4 deficiency and recurrent bacterial blepharokeratoconjunctivitis. Am. J. Ophthalmol., Marion, v.98, n.2, p.243-244, 1984. [Letter].

IUIS/WORLD HEALTH ORGANIZATION. Notice. Appropriate uses of human immunoglobulin in clinical IUIS/WHO report laboratory investigations in clinical immunology: methods, pitfalls and clinical indications. Clin. Exp. Immunol., Oxford, v.74, p.494-503, 1988. 
JEFFERIS, R., KUMARARATNE, D.S. Selective IgG subclass deficiency: quantification and clinical relevance. Clin. Exp. Immunol., Oxford, v.81, p.357-367,1990.

JEFFERIS, R., REIMER, C.B., SKVARIL, F., DE LANGE, G., LING, N.R., LOWE, J., WALKER, M.R., PHILLIPS, D.J., ALOISIO, C.H., WELLS, T.W. Evaluation of monoclonal antibodies having specificity for human IgG subclasses: results of an IUIS/WHO collaborative study. Immunol. Lett., Amsterdam, v.10, p.223-252, 1985.

JOHNSON, A.J., MacDONALD, V.E., SEMAR, M., FIELDS, J.E., SCHUCK, J., LEWIS, C., BRIND, J.M. Plasma protein fractionation using solid phase polyelectrolytes. In: CURLING, J.M., ed. Methods of plasma protein fractionation. New York: Academic Press, 1980. p.129-147.

KANKI, P.J., DE COCK, K.M. Epydemiology and natural history of HIV. AIDS, London, v.8, suppl. 1, p.S85-S93, 1994.

KEMPF, C., JENTSCH, P., POIRIER, B., BARRE-SINOUSSI, F., MORGENTHALER, J.J., MORELL, A., GERMANN, D. Virus inactivation during production of intravenous immunoglobulin. Transfusion, Bethesda, v.31, n.5, p.423-427, 1991.

KISTLER, P., NITSCHMANN, H. Large scale production of human plasma fractions. Vox. Sang., Basel, v.7, p.414-424, 1962.

KLINE, M.W., SHEARER, W.T. Active and passive immunization in the prevention of infections diseases. In: STIEHM, E.R., ed. Immunologic disorders in infants and children. 4.ed. Philadelphia: WB Saunders, 1996. p.950-953.

KLINGEBIEL, T., PICKERT, A., DOPFER, R., RANKE, M.B., SIEDNER, R. Unusual course of a Chlamydia pneumonia in an infant with IgG2/lgG4deficiency. Eur. J. Pediatr., Berlin, v.148, n.5, p.431-434, 1989. 
LAL, R.B., BRODINE, S., KAZURA, J., MBIDDE-KATONGA, E., YANAGIHARA, R., ROBERTS, C. Sensitivity and specificity of a recombinant transmembrane glycoprotein (rgp21) - spiked Western imunoblot for serological confirmation of human T-cell lymphotropic virus type I and type II infections. J. Clin. Microbiol., Washington, v.30, p.296299, 1992.

LANDSTEINER, K. Überr agglutinationserscheinungen normalen menschlichen blutes. Klin. Wschr., v.14, p.1132, 1901. Apud: MOLLISON, P.L., ENGELFRIET, C.P., CONTRERAS, M. Blood transfusion in clinical medicine. 10.ed. Oxford: Blackwell Scientific, 1997. p.116-150.

LAWLOR, E., POWER, J., GARSON, J., YAP, P., DAVIDSON, F., COLUMB, G., SMITH, D., POMEROY, L., O'RIORDAN, J., SIMMONDS, P., TEDDER, R. Transmission rates of hepatitis $C$ virus by different batches of a contaminated anti-D immunoglobulin preparation. Vox Sang., Basel, v.76, n.3, p.138-143, 1999.

LEFRÈRE, J.J., MARIOTTI, M., TREPO, C., LI, J.S., LUNEL, F., FRANGEUL, L., LETOURNEUR, F., LAPORTE, J.P., JULLIEN, A.M. Testing for HCV-RNA in commercial intravenous immunoglobulins. Lancet, London, v.341, p.834-835, 1993.

LEMON, S.M. The natural history of hepatitis $A$ : the potencial for transmission by transfusion of blood or blood products. Vox Sang., Basel, v.67, suppl. 4, p.19-23, 1994.

LEVY, Y., ALLARY, M., KONNERADT, P., BOSCHETTI, E., SAINTBLANCHARD, J. Chromatographic approaches in the purification of factor VIII. In: CURLING, J.M., ed. Separation of plasma proteins. Uppsala: Pharmacia Fine Chemicals AB, 1983. p.205-211.

LiautAud, J., PlA, J., DEBrus, A., GATTEl, P., Plan, R., PEYRON, L. Préparation de l'albumine humaine à partir de sang hémolysé extrait de 
placentas congéles. Technique de préparation et qualité du produit. Develop. Biol. Standard, v. 27, p.104-114, 1974. Apud: In: CURLING, J.M., ed. Separation of plasma proteins. Uppsala: Pharmacia Fine Chemicals $A B$, 1983. p.6-33.

LIPKA, J.J., YOUNG, K.K.Y., KWOK, S.Y., REYES, G.R., SNINSKY, J.J., FOUNG, S.K.H. Significance of human T-lymphotropic virus type I indeterminant serological findings among healthy individuals. Vox. Sang., Basel, v.61, p.171-176, 1991.

LISBOA, C.P. Detecção do Parvovírus humano B19 em doadores de sangue, utilizando a técnica de reação de polimerização em cadeia (PCR). São Paulo, 1997. 99p. (Dissertação de Mestrado - Instituto de Ciências Biomédicas - USP).

LOH, R.K., HARTH, S.C., THONG, Y.H., FERRANTE, A. Immunoglobulin G subclass deficiency and predisposition to infection in Down's syndrome. Pediatr. Infect. Dis. J., Baltimore, v.9, n.8, p.547-551, 1990.

LOH, R.K., THONG, Y.H., FERRANTE, A. Deficiency of IgG subclasses and $\lg A$, and elevation of $\lg \mathrm{E}$ in children with a past history of bacterial meningitis. Acta Paediatr. Scand., Stockholm, v.80, n.6/7, p.654-658, 1991.

MARRACK, J.R., RICHARDS, C.B. Ligth-scattering of the formation of aggregates in mixtures of antigen and antibody. Immunology, Oxford, v.20, p.1019-1022, 1971.

McCUE, J.P., HEIN, R.H., TENOLD, R. Three generations for immunoglobulin $G$ preparations of clinical use. Review of infectious diseases. Vox Sang., Basel, v.8, p.374-381, 1986.

McFARLANE, I.G., SMITH, H.M., JOHNSON, P.J. BRAY, G.P., VERGANI, D., WILLIAMS, R. Hepatitis C virus antibodies in chronic active hepatitis: 
pathogenic factor or false-positive result? Lancet, London, v.335, p.354357, 1990.

MIELKA, S.I., GOZZE, I. Anticomplementary activity of human immunoglobulin G. I. Mechanism of the artifactual increase in anticomplementary activity of IgG during the assay. Vox Sang., Basel, v.29, p.101-123, 1975.

MOLLISON, P.L., ENGELFRIET, C.P., CONTRERAS, M. Blood transfusion in clinical medicine. 10.ed. Oxford: Blackwell Scientific, 1997. 754p.

MOREIRA Jr., E.D., RIBEIRO, T.T., SWANSON, P., SAMPAIO, C.F., MELO, A., BRITES, C., BADARÓ, R., TOEDTER, G., LEE, H., HARRINGTON Jr., W. Seroepidemiology of human T-cell lymphotropic virus type I/I in Northeastern Brazil. JAIDS, J. Acquired Immune Defic. Syndr., Hagerstown, v.6, p.959-963, 1993.

MORELL, A. Various immunoglobulin preparations for intravenous use. Vox Sang., Basel, v.51, p.44-49, 1986.

MOSS, R.B., CAMARCK, M.A., ESRIG, S. Deficiency of IgG4 in children: association of isolated IgG4 deficiency with recurrent respiratory tract infection. J. Pediatr., St. Louis, v.120, n.1, p.16-21, 1992.

MULLIS, K.B., FALOONA, F.A. Specific synthesis of DNA in vitro via a polymerase-catalysed chain reaction. Methods Enzymol., San Diego, v.155, p.335-380, 1987.

NAKAMURA, S., SATO, T. Acute hepatitis B after administration of gammaglobulin. Lancet, London, v.1, n.7957, p.487, 1976.

NETO, G.V. Meta mobilizadora nacional do setor de saúde. Bol. Fed. Hemofília, São Paulo, jan., 2001. p.4. 
NEWMAN, J., JOHNSON, A.J., KARPATKIN, M.H., PUSZKIN, S. Methods for the production of clinically effective intermediate and high purity factor VIII concetrates. Br. J. Haematol., Oxford, v.21, p.1-20, 1971.

NISHIZAWA, T., OKAMOTO, H., KONISHI, K. A novel DNA-virus (TTV) associated with elevated transaminases levels in post transfusion hepatitis of unknow etiology. Biochem. Biophys. Res. Commun., Orlando, v.241, n.1, p.92-97, 1997.

NYDEGGER, U.E., MOHACSI, P.J., ESCHER, R., MORELL, A. Cilnical use of intravenous immunoglobulins. Vox Sang., Basel, v.78, suppl. 2, p.191195, 2000.

ONCLEY, J., MELIN, M., RICHERT, D.A., CAMERON, J.W., GROSS Jr., P.M., The separation of antibodies, isoaagglutinines prothrombin, plasminogen and beta-lipoprotein into subfractions of human plasma. $\mathbf{J}$. Am. Chem. Soc., Columbus, v.71, p.541-550, 1949.

ORGANIZAÇÃO MUNDIAL DA SAÚDE. Comitê de Peritos em Especificações para Preparados Farmacêuticos. Boas práticas para a fabricação de produtos farmacêuticos: $32^{\circ}$ Informe. Brasília: Ministério da Saúde, SVS, OMS, 1994. 144p. (Série Relatórios Técnicos, n 823).

ORGANIZACIÓN MUNDIAL DE LA SALUD. Comitê de Especialistas en Patrones Biológicos. Normas para los productos provenientes de grandes mezclas de sangre: 43 Informe. Genebra: OMS (WHO), 1994. p.91-96. (Série de Informes Técnicos, n`840).

OUCHTERLONY, O. Antigen-antibody reactions in gels. Acta. Pathol. Microbiol. Scand., Copenhagen, v.26, p.507-515, 1949.

OXELIUS, V.A., HANSON, L.A., BJORKANDER, J., HAMMARSTROM, L., SJOHOLM, A. IgG3 deficiency: common in obstructive lung disease. hereditary in families with immunodeficiency and autoimmune disease. Monogr. Allergy, Basel, v.20, p.106-115, 1986. 
PAGE, R., FRIDAY, G., STILlWAGON, P., SKONER, D. CALIGUIRI, L., FIREMAN, P. Asthma and selective immunoglobulin subclass deficiency: improvement of asthma after immunoglobulin replacement therapy. $\mathbf{J}$. Pediatr., St. Louis, v.112, n.1, p.127-131, 1988.

PARSLOW, T.G. Lymphocytes \& lymphoid tissues. In: STITES, D.P., TERR, A.I., eds. Basic and clinical immunology. 8.ed. Norwalk: Appleton \& Lange, 1994. p.22-39.

RAWLS, W.E. Diagnostic procedures for viral rickettsial and chlamydial infections. In: LENNETFE, E.H., SCHMIDT, N.J., eds. Washington: American Public Health Association., 1979. p.309-360.

REWALD, E., MORELL, A. Immunomodulation by intravenous immunoglobulin. New York: Parthenon, 1993. 244p.

ROBERTON, D.M., COLGAN, T., FERRANTE, A., JONES, C., MERMELSTEIN, N., SENNHAUSER, F. IgG subclass concentrations in absolute, partial and transient IgA deficiency in childhood. Pediatr. Infect. Dis. J., Baltimore, v.9, suppl. 8, p.541-545, 1990.

ROILIDES, E., BLACK, C., REIMER,C., RUBIN, M., VENZON, D., PIZZO, $P . A$. Serum immunoglobulin $G$ subclasses in children infected with human immunodeficiency virus type 1. Pediatr. Infect. Dis. J., Baltimore, v.61, n.3, p.134-139, 1991.

ROTHSTEIN, F., ROSENOER, V.M., HUGHES, W.L. Current concepts concerning albumin purification. In: ROSENOER, V.M., ORATZ, M., ROTHSCHILD, M.A., eds. Albumin structure, function and uses.. Oxford: Pergamon Press, 1977. p.7-25.

SÁEZ-ALQUÉZAR, A., BASSIT, L., BARRETO, C.C., PINHO, J.R.R., DORLHIAC-LLACER, P.E., CHAMONE, D.A.F. Prevalence of anti-HTLV I antibodies in blood donors, São Paulo, Brazil. In: ENCONTRO NACIONAL DE VIROLOGIA, 6, São Lourenço, 1992. Programas e 
Resumos. Belo Horizonte: Sociedade Brasileira de Virologia, 1992. p.208.

SÁEZ-ALQUÉZAR, A., BASSIT, L., SABINO, E.C. Hepatites. In: FERREIRA, A.W., ÁVILA, S.L.M., eds. Diagnóstico laboratorial. Rio de Janeiro: Guanabara Koogan, 1996. p.37-49.

SÁEZ-ALQUÉZAR, A., BASSIT, L., TANAKA, V.M., NOZAWA, T.M., DORLHIAC-LLACER, P.E., CHAMONE, D.A.F. Soroprevalência do vírus da hepatite $B$ em doadores de sangue na Fundação Pró-Sangue Hemocentro de São Paulo. Bol. Rev. Soc. Bras. Hematol. Hemoter., São Paulo, v.16, n.165, p.133, 1994. [Congresso Brasileiro de Hematologia e Hemoterapia, 21, São Paulo, 1994. Resumo].

SÁEZ-ALQUÉZAR, A., BASSIT, L., TANAKA, V.M., NOZAWA, T.M., DORLHIAC-LLACER, P.E., CHAMONE, D.A.F. Prevalência de anticorpos anti-HCV em candidatos à doação de sangue na Fundação Pró-Sangue Hemocentro de São Paulo. Bol. Rev. Soc. Bras. Hematol. Hemoter., São Paulo, v.16, n.165, p.132, 1994. (Congresso Brasileiro de Hematologia e Hemoterapia, 21, São Paulo, 1994. Resumo].

SANCHEZ, M.C.A. Testes sorológicos. In: FERREIRA, A.W., ÁVILA, S.L.M., eds. Diagnóstico laboratorial. Rio de Janeiro: Guanabara Koogan, 1996. p.7-28.

SCHNEIDER, W., LEFEVRE, H., FRIEDLER, H., McCARTY, L.J. An alternative method of large scale plasma fractionation for the isolation of serum albumin. Blut, Berlin, v.30, p.121-134, 1975.

SCOTT, M.G., SHACKELFORD, P.G., BRILES, D.E., NAHM, M.H. Human IgG subclasses and their relation to carbohydrate antigen immunocompetence. Diagn. Clin. Immunol., Washington, v.5, n.5, p.241-248, 1988. 
SEGURADO, A.A.C. HTLV-I: aspectos virológicos e caracterização de subtipos virais. In: VERONESI, R., FOCACCIA, R., eds. Retroviroses humanas: doenças associadas ao HTLV - etiologia, patogenia, patologia clínica, tratamento, prevenção. São Paulo: Atheneu, 2000. p.1-9.

SEGURADO, A.A.C. Infecção por HTLV I e HTLV II. In: FERREIRA, A.W., ÁVILA, S.L.M., eds. Diagnóstico laboratorial. Rio de Janeiro: Guanabara Koogan, 1996. p.56-61.

SHACKLEFORD, P.G., POLMAR, S.H., MAYUS, J.L., JOHNSON, W.L., CORRY, J.M., NAHM, M.H. Spectrum of IgG2 subclass deficiency in children with recurrent infections: prospective study. J. Pediatr., St. Louis, v.108, n.5 (pt.1), p.647-653, 1986.

SHAKIB, F., STANWORTH, D.R. Human IgG subclasses in health and disease (part I). Ric. Clin. Lab., Milan, v.10, p.463-479, 1980a.

SHAKIB, F. , STANWORTH, D.R. Human IgG subclasses in health and disease (part II). Ric. Clin. Lab., Milan, v.10, p.561-580, 1980b.

SHIELD, J.P.H., STROBEL, S., LEVINSKY, R.J., MORGAN, G. Immunodeficiency presenting as hypergammaglobulinaemia with $\operatorname{IgG} 2$ subclass deficiency. Lancet, London, v.340, p.448-450, 1992.

SIMONS, J.N., LEARY, T.P., DAWSON, G.J., et al. Isolation of novel virus like sequences associated with human hepatitis. Nat. Med., New York, v.6, n.1, p.564-569, 1995.

SINHA, N.D., BIERNAT, J., McMANUS, J., KOSTER, H. Polymer support oligonucleotide synthesis XVIII: use of beta-cyanoethyil- $\mathrm{N}, \mathrm{N}$ dialkylamino-N-morpholino phosphoramidite of deoxynucleosides for the synthesis DNA fragments simplifying deprotection and isolation of the final product. Nucl. Acid. Res., Oxford, v.12, p.4539-4557, 1984.

SKVARIL, F., SCHERZ, R. IgG subclasses in IgA-deficients patients with anti-IgA antibodies. Monogr. Allergy, Basel, v.20, p.164-170, 1986. 
SMITH, J.K., BIDWELL, E. Therapeutic materials used in the treatment of coagulation defects. Clin. Haematol., London, v.8, p.183-206, 1979.

SODERSTROM, T., SODERSTROM, R., BENGTSSON, U., BJORKANDER, J., HELLSTRAND, K., HOLM, J., HANSON, L.A. Clinical and immunological evaluation of patients low in single or multiple IgG subclasses. Monogr. Allergy, Basel, v.20, p.135-142, 1986.

SODERSTROM, T., SODERSTROM, R., ENSKOG, A. Immunoglobulin subclasses and prophylactic use of immunoglobulin in immunoglobulin $G$ subclass deficiency. Cancer, New York, v.68, suppl. 6, p.1426-1429, 1991.

STEMBERG, J.C. A rate nephelometer for measuring specific proteins by immunopreciptation reactions. Clin. Chem., Washington, v.23, p.14561460, 1977.

SUOMELA, H., BERGLÖF, J.H., HÄMÄLÄINEN, E., ERIKSSON, S., CURLING, J.M. Imunoglobulin $G$ for intravenous use: preparation and in vitro properties. In: CURLING, J.M., ed. Separation of plasma proteins. Uppsala: Pharmacia Fine Chemicals AB, 1983. p.127-130.

SUOMELA, H. Inactivation of viruses in blood and plasma products. Transf. Med. Rev., Orlando, v.7, p.42-57, 1995.

TAN, D., MATSUMOTO, A., YEO, A., SHIH, J.W.K., ALTER, H.J., YU, M.W. Detection of TT virus in factor VIII concentrates and other plasma derivatives. In: Internacional Symposium on Hepatitis $C$ and Related Viruses, 6., Bethesda, 06-09 jun. 1999. Resumos. Bethesda, National Institute of Health $(\mathrm{NIH})$, 1999. p.331.

TANAKA, K., SAWATANI, E., ARASHIRO, F., OLIVEIRA, G.A. Produção de IgG intravenosa pelo método de cromatografia em coluna. Laes/Haes, São Paulo, v.84, p.52-56, 1993. 
TANAKA, K., SAWATANI, E., ARASHIRO, F., OLIVEIRA, G.A. Estudo prelimin ar de remoção de isoaglutininas anti-A e anti-B da imunoglobulina $\mathrm{G}$ através de imunoadsorvente sintético. Laes/Haes, São Paulo, v.87, p.14-26, 1994.

TANAKA, K., SAWATANI, E., NAKAO, H.C., DIAS, G.A., ARASHIRO, F. An alternative column chromatographic process for the production of human albumin. Braz. J. Med. Biol. Res., Ribeirão Preto, v.29, p.185-191, 1996.

TANAKA, K., SAWATANI, E., SHIGUEOKA, E.M., CAMPOS, T.C.X.B., NAKAO, H.C., DIAS, G.A., FUJITA, R.K. , ARASHIRO, F. A chromatografic method for the production of a human immunoglobulin $G$ solution for intravenous use. Braz. J. Med. Biol. Res., Ribeirão Preto, v.31, n.11, p.1375-1381, 1998.

TERRY, W.D., FAHEY, J.L. Subclasses of human $\gamma$-globulin based on differences in the heavy polypeptide chain. Science, Washington, v.145, p.145-154, 1964.

TOKANO,Y., YAGITA, H., IIDA, N., HASHIMOTO, H., OKUMURA, K., HIROSE, S. Relation between the level of IgG subclasses and infections in patients with systemic lupus rrythematosus. Int. Arch. Allergy Appl. Immunol., Basel, v.87, n.1, p.55-58, 1988.

TOWBIN, H., STAEHLIN, T., GORDON, J. Electrophoretic transfer of proteins from polyacrylamide gels to nitrocellulose sheets: procedure and some applications. Proc. Natl. Acad. Sci. U.S.A, Washington, v.76, p.4350-4354, 1976.

UEMURA, Y., JOY HANG, Y.H., HELDEBRANT, C.M., TAKECHI, K., YOKOYAMA, K. Inactivation and elimination of viruses during preparation of human intravenous immunoglobulin. Vox Sang., Basel, v.67, p.246254, 1994. 
UNITED States Pharmacopeia. 23.ed. Rockville: United States Pharmacopeial Convention, 1995. 2391p.

USHIDA, T., SHIMOJIMA, M., GOTOH, K., KIOSAWA, K. "Silent" hepatitis B virus mutants are responsible for non- $A$, non- $B$, non- $D$, non- $E$ hepatitis. Microbiol. Immunol., Tokyo, v.38, p.281-285, 1994.

VAZ, C.A.C., FERRI, R.G., GEISTHOVEL, N., CAMPOS, A.N.P. Eletroforese sobre acetato de celulose (CAF). Reprodutibilidade e valores normais. Rev. Inst. Adolfo Lutz, São Paulo, v.31, p.71-75, 1975.

WELLER, T.H., COONS, A.H. Fluorescent antibody: studies with agents of varicella and herpes zoster propagated in vitro. Proc. Soc. Exp. Biol. Med., Malden, v.86, p.789-794, 1954.

WORLD HEALTH ORGANIZATION. Expert Committee on Biological Standardization. Report of an informal meeting on intravenous immunoglobulins (human). Geneva: WHO, 1982.

WILL, R.G., IRONSIDE, J.W., ZEIDLER, M., COUSENS, S.N., ESTIBEIRO, K., AlPEROVItCH, A., POSER, S., POCChIARI, M., HOFMAN, A., SMITH, P.G. A new variant of Creutzfeldt-Jakob disease in U.K. Lancet, London, v.347, p.921-925, 1996.

WICKERHAUSER, M. Large-scale preparation of factor VIII- concentrate from frozen cryoethanol precipitate. Thromb. Diath. Haemorrh., Suppl., Stuttgart, n.43, p.165-173, 1971.

WONG, D.C., DIWAN, A.R., ROSEN, L., GERIN, J.L., JOHNSON, R.G., POLITO, A., PURCELL, R.H. Non-specificity of anti-HCV test for seroepidemiological analysis. Lancet, London, v.336, p.750-751, 1990.

WORDELL, C.J. Use of intravenous immune globulin therapy: an overview. DICP, Ann. Pharmacother., Cincinnati, v.25, p.805-817, 1991. 
YAP, P.L. Supply of blood products. Br. Med. J., London, v.302, p.15381542, 1991.

YAP, P.L. The viral safety of intravenous immune globulin. Clin. Exp. Immunol., Oxford, v.104, suppl. 1, p.35-42, 1996.

YAP, P.L., LEAVER, H.A., GILLON, J. Prions: properties, occurrence, modes of transmission and relevance for blood transfusion and blood derivatives. Vox Sang., Basel, v.74, suppl. 2, p.131-134, 1998.

YU, M.W., MASON, B.L., TANKERSLEY, D.L. Detection and characterization of hepatitis C virus RNA in immune globulins. Transfusion, Bethesda, v.34, p.596-602, 1994. 